\title{
Islamic Republic of Afghanistan: Enhanced Heavily Indebted Poor Countries Initiative-Decision Point Document and Debt Sustainability Analysis
}

\begin{abstract}
This paper was prepared by staff of the International Monetary Fund and the World Bank in connection with the Executive Board's consideration of the Islamic Republic of Afghanistan's decision point and debt sustainability analysis under the Enhanced Heavily Indebted Poor Countries Initiative. It is based on the information available at the time it was completed on June 8, 2007. The views expressed in this document are those of the staff team and do not necessarily reflect the views of the government of the Islamic Republic of Afghanistan or the Executive Board of the IMF.

The policy of publication of staff reports and other documents by the IMF allows for the deletion of market-sensitive information.
\end{abstract}

To assist the IMF in evaluating the publication policy, reader comments are invited and may be sent by e-mail to publicationpolicy@imf.org.

Copies of this report are available to the public from

International Monetary Fund $\bullet$ Publication Services

700 19th Street, N.W. $\bullet$ Washington, D.C. 20431

Telephone: (202) 6237430 • Telefax: (202) 6237201

E-mail: publications@imf.org • Internet: http://www.imf.org

Price: $\$ 18.00$ a copy

\section{International Monetary Fund Washington, D.C.}





\title{
INTERNATIONAL MONETARY FUND AND \\ INTERNATIONAL DEVELOPMENT ASSOCIATION
}

\section{ISLAMIC REPUBLIC OF AFGHANISTAN \\ Enhanced Heavily Indebted Poor Countries (HIPC) Initiative-Decision Point Document}

\author{
Prepared by the Staffs of the \\ International Monetary Fund and the International Development Association \\ Approved by Juan Carlos Di Tata and Matthew Fisher (IMF) and \\ Praful Patel and Danny Leipziger (IDA)
}

June 8, 2007

Contents Page

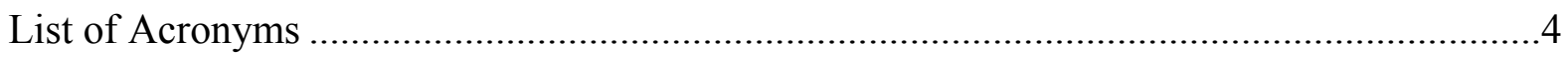

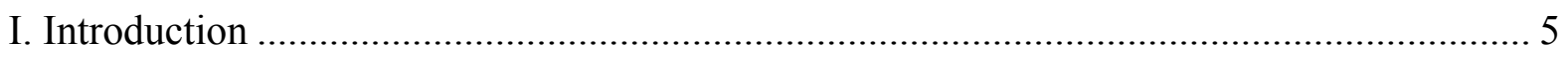

II. Background and Eligibility for HIPC Initiative Assistance........................................ 6

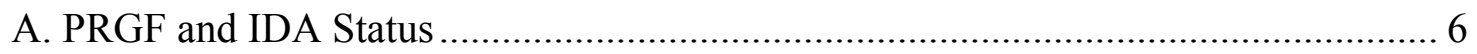

B. Dimensions of Poverty ....................................................................................... 6

C. Recent Political, Security, and Governance Developments .................................... 8

D. Macroeconomic and Structural Reform Track Record ..................................... 9

III. Medium- to Long-Term Strategy for Poverty Reduction ......................................... 13

A. The PRSP Formulation Process ....................................................................... 13

B. Medium- to Long-Term Macroeconomic Outlook ............................................... 14

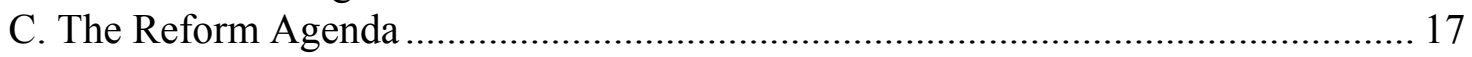

IV. Possible Assistance Under the HIPC Initiative and Debt Sustainability Analysis.......... 20

A. Debt Reconciliation Status............................................................................. 20

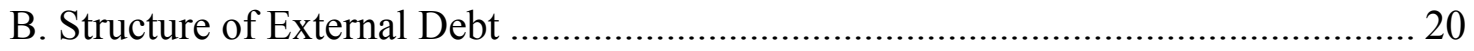

C. Possible Assistance Under the HIPC Initiative .................................................... 23

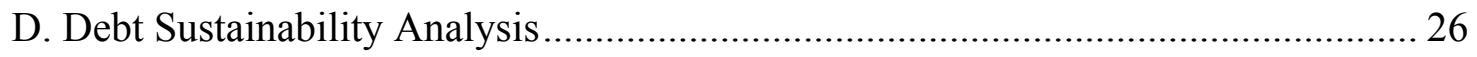

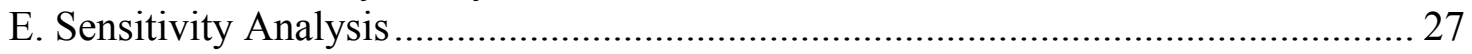

F. MDRI and Possible Bilateral Assistance Beyond HIPC ....................................... 29 


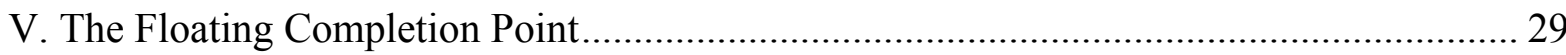

A. Triggers for the Floating Completion Point ............................................................ 29

B. Monitoring the Floating Completion Point Triggers ……………………………..... 31

C. The Use and Monitoring of Public Resources …………………………………..... 32

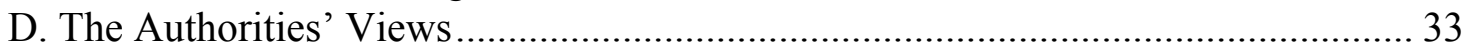

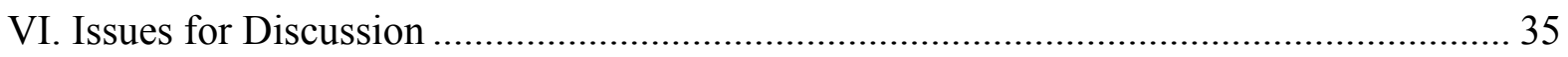

Boxes

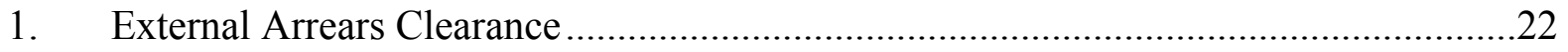

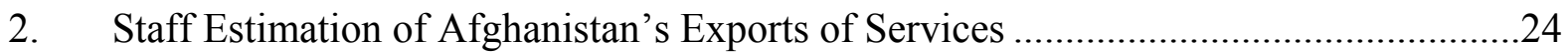

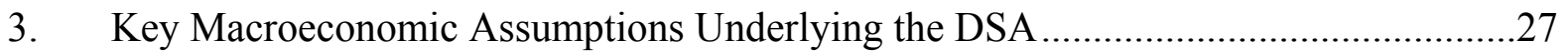

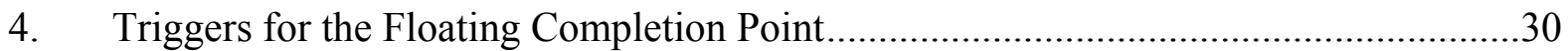

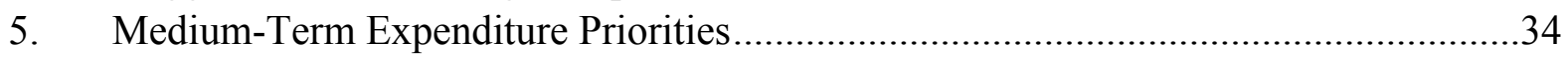

Figures

1. Composition of Stock of External Debt as of March 20, 2006, by Creditor Group .......36

2. Potential Costs of the HIPC Initiative by Creditor Group …….......................................

3. External Debt Sustainability Indicators, 2005/06-2025/26 …......................................37

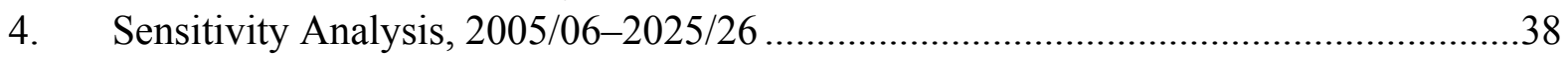

Tables

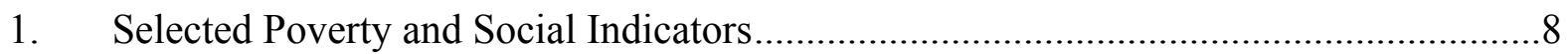

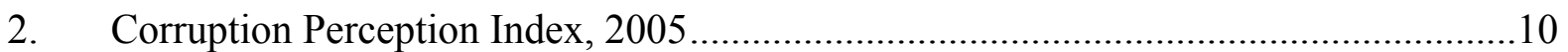

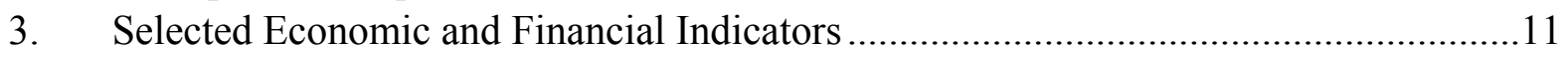

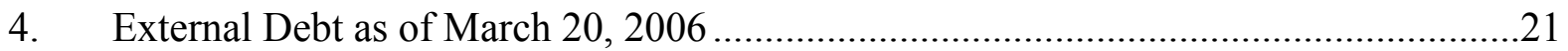

5. HIPC Initiative Assistance Under a Proportional Burden-Sharing Approach: Net

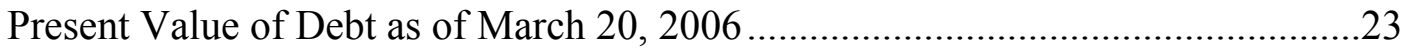

A1. Nominal Stock and Net Present Value of Debt as of March 20, 2006,

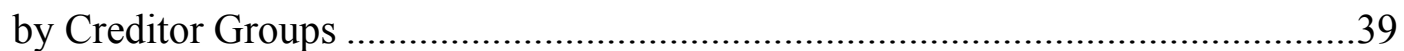

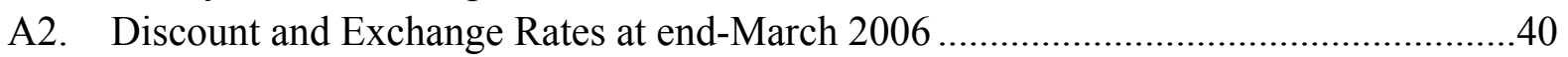

A3. External Debt Service, 2006/07-2025/26 …….....................................................

A4. Net Present Value of External Debt, 2005/06-2025/26 ..........................................42

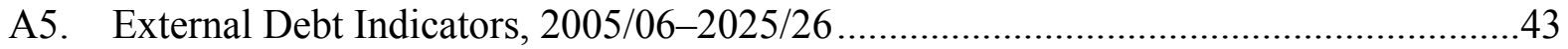

A6. External Debt Indicators and Sensitivity Analysis, 2005/06-2025/26 ……..................44

A7. HIPC Initiative: Status of Country Cases Considered Under the Initiative,

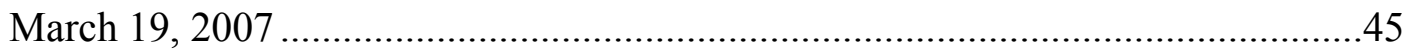

A8. Possible Delivery of IDA Assistance Under the Enhanced HIPC Initiative,

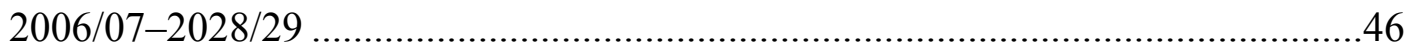

A9. Long-Term Macroeconomic Assumptions, 2006/07-2026/27 .....................................47 
A10. Paris Club Creditors' Delivery of Debt Relief Under Bilateral Initiatives Beyond

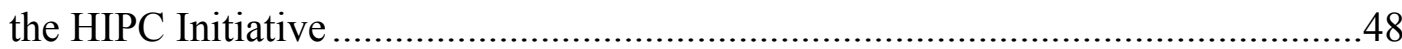

A11. Status of Creditor Participation Under the Enhanced HIPC Initiative

Appendix

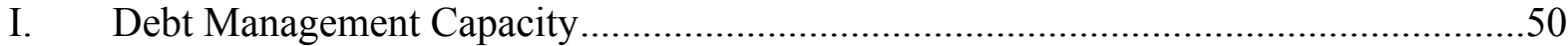




\section{LIST OF ACRONYMS}

ADF

AFMIS

ANDS

ANA

ANP

AsDB

BPHS

CAS

CPIA

DAB

DAMU

DSA

EITI

GDP

GNI

HIPC

I-ANDS

IDA

IMF

ISN

LIC

LICUS

MDG

MDRI

$\mathrm{MoPH}$

MTFF

NPV

NRVA

ODA

OFID

PAR

PFEM

PRGF

PRR

PRSP

SDR

SMP
Afghanistan Development Forum

Afghanistan Financial Management Information System

Afghanistan National Development Strategy

Afghan National Army

Afghan National Police

Asian Development Bank

Basic Package of Health Services

Country Assistance Strategy

Country Policy and Institutional Assessment

Da Afghanistan Bank

Debt and Asset Management Unit

Debt Sustainability Analysis

Extractive Industries Transparency Initiative

Gross Domestic Product

Gross National Income

Heavily Indebted Poor Countries

Interim Afghanistan National Development Strategy

International Development Association

International Monetary Fund

Interim Strategy Note

Low Income Countries

Low Income Countries Under Stress

Millennium Development Goal

Multilateral Debt Relief Initiative

Ministry of Public Health

Medium-Term Fiscal Framework

Net Present Value

National Risk \& Vulnerability Assessment

Official Development Assistance

OPEC Fund for International Development

Public Administration Reform

Public Finance and Expenditure Management

Poverty Reduction and Growth Facility

Priority Reform and Restructuring

Poverty Reduction Strategy Paper

Special Drawing Rights

Staff Monitored Program 


\section{INTRODUCTION}

1. This paper presents an assessment of the Islamic Republic of Afghanistan's qualification for assistance under the Enhanced Heavily Indebted Poor Countries (HIPC) Initiative. ${ }^{1}$ The Executive Boards of the IMF and IDA discussed the preliminary HIPC document for Afghanistan on April 11 and 19, 2007, respectively. ${ }^{2}$ On these occasions, Directors agreed to add Afghanistan to the list of HIPC ring-fenced countries that met the income and indebtedness criteria at end-2004. Directors also preliminarily assessed Afghanistan as being eligible for assistance under the HIPC Initiative and agreed that Afghanistan could reach its Decision Point in mid-2007 provided that: (i) its performance under the PRGF-supported program remains satisfactory; (ii) the government concludes an agreement on the clearance of arrears to the OPEC Fund for International Development (OFID); (iii) negotiations with bilateral creditors on all debts to be treated under the HIPC Initiative have been initiated; and (iv) understandings are reached on appropriate completion point triggers. Regarding the latter, Directors broadly supported the possible triggers outlined in the preliminary document.

\section{The debt relief analysis indicates that Afghanistan's external debt burden, after} the full application of traditional debt relief, is above the HIPC Initiative threshold. As of March 20, 2006 (the latest reconciled end-of-fiscal year debt data), Afghanistan's net present value (NPV) of debt-to-exports ratio is estimated at 306.2 percent after traditional debt relief, which translates into a common reduction factor of 51.0 percent. HIPC debt relief of US\$571.4 million (in NPV terms) would be required to reduce Afghanistan's NPV of debt-to-exports ratio to the HIPC threshold of 150 percent. $^{3}$ The implementation of Afghanistan's poverty reduction strategy, supported by the HIPC Initiative, would help Afghanistan accelerate progress towards the Millennium Development Goals (MDGs).

3. This paper is organized as follows. Section II provides background information on Afghanistan's eligibility for assistance under the HIPC Initiative; the dimensions of poverty; recent political, security and governance developments; and the policy track record. Section III discusses the preparation of the authorities' poverty reduction strategy paper (PRSP) and the future reform agenda, including the medium- to long-term macroeconomic framework. Section IV presents possible HIPC and MDRI assistance, and summarizes the results of the debt sustainability analysis (DSA). Section V discusses the floating completion

\footnotetext{
${ }^{1}$ The Islamic Republic of Afghanistan and the Enhanced HIPC Initiative will hereafter be referred to as Afghanistan and the HIPC Initiative, respectively.

${ }^{2}$ See IMF Country Report No. 07/232, March 27, 2007, and IDA Report No 39093-AF, March $27,2007$.

${ }^{3}$ Under the Multilateral Debt Relief Initiative (MDRI), additional debt relief from IDA is expected to be US\$14.3 million in NPV terms. Afghanistan does not have any IMF debt eligible for MDRI relief.
} 
point triggers, as well as how public resources will be used and tracked after the decision point. It also reports the views of the authorities. Finally, Section VI presents issues for discussion by the Executive Directors.

\section{BACKGROUND AND ELIGIBILITY FOR HIPC INITIATIVE ASSISTANCE}

\section{A. PRGF and IDA Status}

\section{Afghanistan is an IDA-only country with a gross national income (GNI) per} capita of US\$271 in 2005. ${ }^{4}$ The Interim Strategy Note (ISN), discussed by the IDA Board of Executive Directors in May 2006, is guiding IDA's engagement in Afghanistan over the 2006-08 period. It is expected to be followed by a Country Assistance Strategy (CAS) once the government has finalized its full PRSP. ${ }^{5}$

\section{In June 2006, the IMF's Executive Board approved Afghanistan's first} three-year PRGF arrangement, totaling SDR 81 million (50 percent of quota). The IMF Board completed the first review under the arrangement on March 7, 2007. The second review is scheduled to be discussed by the IMF Board in parallel with this document. Afghanistan will continue to need substantial concessional assistance from the international community, and is likely to remain an IDA-only and PRGF-eligible country for the foreseeable future.

\section{B. Dimensions of Poverty}

\section{Protracted conflict and political instability have undermined Afghanistan's} socio-economic development, resulting in widespread poverty and weak social development. Nevertheless, Afghanistan's economy has achieved a major recovery since late 2001, with robust Gross Domestic Product (GDP) growth, albeit from a very low level.

\section{The absence of officially recognized poverty estimates has, to date, prevented a} systematic diagnosis of poverty in Afghanistan. A recent World Bank analysis was the first comprehensive attempt at estimating and studying poverty and its determinants. ${ }^{6}$ The national poverty headcount rate was found to be around 33 percent (estimated using one

\footnotetext{
${ }^{4} \mathrm{GNI}$ is calculated using the World Bank's Atlas methodology. Population estimates are based on the 2003 Multiple Indicator Cluster Survey (MICS) undertaken by Afghanistan's Central Statistics Office (CSO), with the support from the United Nations Children's Fund. However, in the absence of a formal census, population estimates for Afghanistan vary greatly.

${ }^{5}$ The interim PRSP was published in early 2006 (http://www.ands.gov.af/).

${ }^{6}$ Data limitations remain a key constraint for poverty estimation. National Risk \& Vulnerability Assessments (NRVA), which consisted of multi-topic household surveys including consumption/income data, were fielded in 2003 and 2005. NRVA 2003, originally intended to monitor food security, had an incomplete consumption module that rendered poverty measurement difficult; it also had substantial gaps in geographic coverage (i.e., limited to rural areas). Therefore, the Bank's study relied primarily on data from NRVA 2005.
} 
survey conducted during the summer of 2005). Afghanistan's estimated national Gini coefficient of 0.26 points to lower aggregate income inequality than in other countries in South Asia. ${ }^{7}$

8. Afghanistan has made significant progress in some areas of human development. Since 2001, many refugees and other displaced persons have returned and health care coverage has increased, with the Basic Package of Health Services (BPHS) now available to about 90 percent of the population. According to one independent nationwide third-party evaluation (the "balanced score card"), the quality of health care has improved by 35 percent since 2004. Furthermore, the use of health care services has also increased significantly (e.g., the coverage of prenatal care rose from 5 percent in 2003 to 71 percent in 2006).

\section{There has also been a marked increase in the demand for education in} conjunction with accelerated teacher recruitment and school rehabilitation. ${ }^{8}$ As a result, more than half of the estimated 10 million Afghan children are now attending school. Despite the success in increasing enrollment rates, gender disparities in education remain high. However, because schools are perceived as signs of reconstruction and progress, they are the target of attacks and intimidations. ${ }^{9}$

10. The situation of Afghan women also has improved: (i) the new Constitution provides a clear legal basis for their participation in political and economic affairs (a quarter of parliamentarians are women); (ii) school enrollment of girls has increased significantly; and (iii) maternal care and access to reproductive health services have expanded.

\section{Despite these positive trends, Afghanistan still ranks poorly on all human} development indicators. The Global Human Development Report of 2004 ranks it well behind its neighbors, near the bottom of 177 countries. Poverty and social indicators reflect the extent to which health and educational standards have remained at very low levels, reflecting the legacy of conflict and continuing constraints on service delivery (Table 1). There are significant risks of infant and maternal mortality and widespread malnutrition. Adult literacy is extremely low and life expectancy is among the shortest in the world. Although net primary school enrollment ratios have sharply improved, there are serious concerns about the quality of education.

\footnotetext{
${ }^{7}$ In comparison, Gini coefficients for Bangladesh (2005), Pakistan (2001-02), Nepal (2003-04) and Sri Lanka (2002) are $0.31,0.28,0.41$ and 0.40 respectively.

${ }^{8}$ The proportion of school-age children (7-12 years) in Afghanistan-more than 50 percent of the population under 18 years old - is among the highest in the world (about 1 in 5).

${ }^{9}$ According to the Ministry of Education, in 2006, at least 85 students and teachers were killed and insurgents burned down 187 schools, while 350 schools closed because of security concerns. For the same period, Human Rights Watch reported at least 190 bombing, arson and shooting attacks on teachers, school officials, students and schools - up from 91 such attacks reported in 2005.
} 
Table 1. Selected Poverty and Social Indicators

\begin{tabular}{|c|c|c|c|c|}
\hline & $\begin{array}{c}\text { Afghanistan } \\
2003 \\
\end{array}$ & $\begin{array}{c}\text { South Asia } \\
2004\end{array}$ & $\begin{array}{l}\text { HIPC } \\
2004 \\
\end{array}$ & $\begin{array}{c}\text { MDG Target } \\
2020 \\
\end{array}$ \\
\hline GNI per capita, Atlas method (current US\$) & $271^{*}$ & 589 & 336 & $\ldots$ \\
\hline Population (in millions) & $25.7^{*}$ & 1,446 & 541 & $\ldots$ \\
\hline Population growth (annual percent) & 3.9 & 1.7 & 2.4 & $\ldots$ \\
\hline Underweight children under 5 years of age (percent) & $41^{* *}$ & 44 & $\ldots$ & $15^{\star \star \star}$ \\
\hline School enrollment, primary (percent, net) & 54 & 87 & $\ldots$ & 100 \\
\hline Primary completion rate, total (percent of relevant age group) & 45 & 87 & 53 & 100 \\
\hline Literacy rate, youth total (percent of people ages $15-24$ ) & 34 & 87 & 53 & 100 \\
\hline Ratio of female to male primary enrollment & 60 & 90 & 88 & 100 \\
\hline Ratio of young literate females to males (percent ages 15-24) & 30 & 79 & 80 & 100 \\
\hline Mortality rate, under 5 (per 1,000$)$ & 230 & 92 & 160 & 76 \\
\hline Mortality rate, infant (per 1,000 live births) & 140 & 66 & 99 & 46 \\
\hline Immunization, measles (percent of children ages $12-23$ months) & 75 & 61 & 71 & 100 \\
\hline Life expectancy at birth (total years) & 42 & 63 & 49 & $\ldots$ \\
\hline Maternal mortality (per 100,000 live births) & $1,600^{* *}$ & $\ldots$ & $\ldots$ & 800 \\
\hline Births attended by skilled health staff (percent of total) & $14^{* *}$ & 37 & $\ldots$ & 75 \\
\hline Improved water source (percent of population with access) & 23 & 84 & 57 & 62 \\
\hline Improved sanitation facilities (percent of population with access) & $12^{* *}$ & 37 & 33 & 66 \\
\hline
\end{tabular}

Notes: ${ }^{*} 2005,{ }^{* *} 2002,{ }^{* * *} 2015$

Source: GoA (2005 MDG Report); Central Statistics Office; World Bank, Economic and Social Indicators.

\section{Progress in poverty reduction and social development, and improved security} and appropriate priority setting are largely interconnected. Security is contingent upon visible changes in living conditions and maintaining a stable political process, while insecurity remains the main obstacle to delivering basic services (especially in Eastern and Southern parts of the country). Reaching Afghanistan's MDGs will also depend on decisions about how best to target investment. Emphasis will be needed on supporting the rights of women and children, especially with regard to education. It will be equally important to reach out to provinces, and work closely with communities and local authorities in remote rural areas, where problems are particularly acute.

\section{Recent Political, Security, and Governance Developments}

13. Afghanistan's political situation has stabilized since 2001, consistent with the transitional process for electing a representative government agreed in Bonn in December 2001. A new Constitution was adopted in January 2004, the first presidential election was held in October 2004, and elections for the Wolesi Jirga (lower house of the National Assembly) and provincial councils took place in September 2005. The December 2005 inauguration of the National Assembly marked the formal conclusion of the Bonn political transition process.

14. Despite these achievements, security challenges remain. Security has deteriorated during the past year, particularly in the south and east of the country, with the government unable to enforce policies and laws in some provinces. A Disarmament, Demobilization, and Reintegration initiative has been completed and a follow-up program was initiated (the 
Disbandment of Illegal Armed Groups program). Although there is now a 36,000-strong Afghan National Army (ANA) and most of the Afghan National Police (ANP) has been trained, their capacity to provide security across the country remains limited and there will be a need for continued reliance on foreign support for many years. The opium economy also continues to pose complex risks that are interrelated with security and governance issues. ${ }^{10}$ Dependence on opium production distorts the economy and discourages the development of legitimate economic activities. Drug-related corruption and crime undermine the institution-building process and appear to have compromised certain parts of government (the police in particular).

\section{Weak institutions and challenges in promoting good governance and reducing} corruption seriously hamper economic growth and improvements in living standards. Capacity and political institutions remain weak, and there is an urgent need for a better legal and regulatory framework. Patronage is common in the civil service, and low pay scales have made it difficult to establish a professional merit-based civil service. Afghanistan was ranked in the bottom third of Transparency International's 2005 Corruption Perception Index ( $117^{\text {th }}$ of 158 countries) (Table 2$)$, which —along with a lack of basic factors of production (e.g., electricity and human capital) and a devastated infrastructure - has been a serious impediment to private sector development. Afghanistan ranked $162^{\text {nd }}$ of 175 countries in the World Bank's 2007 Doing Business Report, compared with an average ranking of 105 in South Asia.

\section{Macroeconomic and Structural Reform Track Record}

\section{Sustained economic growth is fundamental to addressing Afghanistan's low} national income and substantial poverty. The government's interim PRSP - the Interim Afghanistan National Development Strategy (I-ANDS) - articulates a reform agenda around three pillars: (i) security; (ii) governance, the rule of law and human rights; and (iii) economic and social development. It is supported by the Afghanistan Compact, a five year framework (2006-2010) based on mutual commitments between the government and its international development partners, with detailed benchmarks and timelines. Both the Bank and Fund are supporting aspects of the strategy, and monitoring progress, through financial support and technical assistance.

\footnotetext{
${ }^{10}$ Opium production accounts for around a quarter of total (drug inclusive) GDP. More than a tenth of the population is estimated to be directly involved in opium cultivation, while others rely on it indirectly.
} 
Table 2. Corruption Perception Index, 2005

\begin{tabular}{|c|l|c|}
\hline Country Rank & \multicolumn{1}{|c|}{ Country } & CPI Score* \\
\hline 103 & Gambia & 2.7 \\
\hline 107 & Eritrea & 2.6 \\
\cline { 2 - 3 } & Honduras & 2.6 \\
\cline { 2 - 3 } & Kazakhstan & 2.6 \\
\cline { 2 - 3 } & Nicaragua & 2.6 \\
\cline { 2 - 3 } & Zambia & 2.6 \\
\hline \multirow{7}{*}{117} & Afghanistan & 2.5 \\
\cline { 2 - 3 } & Bolivia & 2.5 \\
\cline { 2 - 3 } & Nepal & 2.5 \\
\cline { 2 - 3 } & Uganda & 2.5 \\
\hline \multirow{5}{*}{126} & Albania & 2.4 \\
\cline { 2 - 3 } & Niger & 2.4 \\
\cline { 2 - 3 } & Sierra Leone & 2.4 \\
\hline \multirow{7}{*}{130} & Burundi & 2.3 \\
\cline { 2 - 3 } & Congo, Republic of & 2.3 \\
\cline { 2 - 3 } & Kyrgyzstan & 2.3 \\
\cline { 2 - 3 } & Papua New Guinea & 2.3 \\
\hline
\end{tabular}

\begin{tabular}{|c|l|c|}
\hline Country Rank & \multicolumn{1}{|c|}{ Country } & CPI Score* \\
\hline \multirow{10}{*}{137} & Cameroon & 2.2 \\
\cline { 2 - 3 } & Ethiopia & 2.2 \\
\cline { 2 - 3 } & Iraq & 2.2 \\
\cline { 2 - 3 } & Liberia & 2.2 \\
\cline { 2 - 3 } & Uzbekistan & 2.2 \\
\hline \multirow{10}{*}{144} & Congo, Democratic Republic & 2.1 \\
\cline { 2 - 3 } & Pakistan & 2.1 \\
\cline { 2 - 3 } & Somalia & 2.1 \\
\cline { 2 - 3 } & Sudan & 2.1 \\
\cline { 2 - 3 } & Tajikistan & 2.1 \\
\hline \multirow{5}{*}{152} & Cote d'Ivoire & 1.9 \\
\cline { 2 - 3 } & Equatorial Guinea & 1.9 \\
\hline \multirow{3}{*}{155} & Haiti & 1.8 \\
\cline { 2 - 3 } & Turkmenistan & 1.8 \\
\hline & Bangladesh & 1.7 \\
\cline { 2 - 3 } & Chad & \\
\hline
\end{tabular}

Source: Transparency International, 2005.

Notes: Countries in italics are HIPC/HIPC eligible countries (some pre-decision point), ${ }^{*} \mathrm{CPI}$ Score relates to perceptions of the degree of corruption as seen by business people and country analysts, and ranges between 10 (highly clean) and 0 (highly corrupt).

\section{Over the past few years, Afghanistan has made significant progress toward} laying durable foundations for macroeconomic stability and an open-market economy (Table 3). A new and stable currency was introduced in October 2002; inflation declined to 4.8 percent in 2006/07; and reforms aimed at achieving medium-term fiscal sustainability were adopted. These improvements provided an environment conducive to strong economic growth: real non-opium GDP has grown, on average, by 11.3 percent a year over the past four years, driven by strong performance of services and reconstruction-related activities. In March 2004, the authorities embarked on an IMF staff monitored program (SMP). Sustained good performance under the SMP paved the way for a three-year arrangement under the PRGF, which was approved in June 2006. Performance under the PRGF-supported program has been satisfactory. Most quantitative and structural targets for the first year of the program were met, and the second review under the PRGF arrangement is expected to be considered by the IMF Board concurrently with this document. Yet, there are signs that the structural reform agenda is waning and there is mounting pressure from special interests.

\section{On the structural side, the government has initiated wide-ranging reforms and}

has achieved tangible results over the past five years. The reform agenda has centered on: (i) budget formulation, execution, and reporting; (ii) public administration; (ii) regulatory reform in the energy and mining sector; and (iv) transparency and accountability for human development outcomes. However, many reforms are still under way, and weak public administration and poor governance continue to be a major constraint. Moreover, relative to 
Table 3. Selected Economic and Financial Indicators

Financial Year begins on March 21

\begin{tabular}{|c|c|c|c|c|}
\hline & $2003 / 04$ & $2004 / 05$ & $2005 / 06$ & $\frac{\text { Est. }}{2006 / 07}$ \\
\hline \multicolumn{5}{|c|}{ (Annual percentage change, unless otherwise indicated) } \\
\hline GDP at constant prices & 15.7 & 8.0 & 14.0 & 7.5 \\
\hline Real GDP per capita & 10.8 & 3.9 & 9.7 & 3.4 \\
\hline Consumer prices (end-of-period) & 10.3 & 14.9 & 9.4 & 4.8 \\
\hline Central government core budget balance, incl. grants (percent of GDP) & -3.0 & -1.2 & 0.9 & -2.7 \\
\hline Currency in circulation & 39.3 & 34.6 & 15.1 & 12.4 \\
\hline Net international reserves (millions of U.S. dollars) & 766.1 & $1,248.7$ & $1,629.5$ & $1,773.5$ \\
\hline Gross official reserves (millions of U.S. dollars) & 819.6 & $1,283.3$ & $1,661.8$ & $2,062.7$ \\
\hline In months of following year's imports of goods and services & 3.1 & 4.1 & 4.5 & 5.0 \\
\hline
\end{tabular}

Sources: Central Statistical Office, Da Afghanistan Bank, Ministry of Finance, and Fund staff estimates.

the impressive speed of earlier actions, maintaining momentum on the structural agenda requires hard policy decisions and reinvigorating political will. The following describes the progress made in implementing structural and economic reforms, which are the focus of World Bank budget support, IMF technical assistance and bilateral donor support.

- Budget formulation, execution and reporting. Since 2001, much progress has been made in addressing weaknesses in budget practices and the payments system. The introduction of a Medium-Term Fiscal Framework (MTFF), and the integration of the operating and development budgets have improved the quality of budget formulation. With respect to budget execution, fiduciary controls have been enhanced through:

(i) enacting a Public Finance and Expenditure Management (PFEM) Law;

(ii) implementing the computerized Afghanistan Financial Management Information System (AFMIS); (iii) introducing a Treasury Single Account; and (iv) using the Afghanistan Reconstruction Trust Fund's (ARTF) ${ }^{11}$ Monitoring Agent to post-audit transactions. Finally, the government has demonstrated its commitment to transparency by improving financial reporting. The 2005/06 budget was audited and the report was sent to Parliament within the time frame specified in the PFEM law.

\footnotetext{
${ }^{11}$ The multilateral Afghanistan Reconstruction Trust Fund (ARTF) was set up in May 2002 to support Afghanistan by: (i) providing for the recurrent costs of the government; and (ii) financing investment projects, capacity building, feasibility studies, technical assistance, and the return of expatriate Afghans. The ARTF has emerged as one of the main instruments for financing the country's recurrent budget deficit, and is a major resource for technical assistance and investment support. The ARTF is financed by 24 international donors and is administered by the World Bank under the supervision of a Management Committee also including the Asian Development Bank, Islamic Development Bank, and United Nations Development Program. A monitoring agent has been recruited to assist in ensuring proper fiduciary management.
} 
- Public administration. The government's public administration reforms aim to strengthen capacity by raising basic skills and management, and putting in place an adequate pay scale to attract qualified personnel. A central element of the initial Public Administration Reform (PAR) program - adopted in 2002 - was the Priority Reform and Restructuring (PRR) scheme, which placed more than 43,000 positions in 32 ministries and agencies on an elevated pay scale. The authorities also introduced merit-based recruitment, under which there have been about 8,700 appointments (of which 1,400 were for senior civil servants). Both the PAR and PRR have experienced implementation problems and delays, and questions about their fiscal and political sustainability. In 2005, the government adopted a revised PAR strategy, shifting the focus toward comprehensive reforms including: (i) administrative; (ii) salaries and incentives; (iii) civil service management; (iv) merit-based appointments; and (v) capacity enhancement. Importantly, the government recently adopted a set of monitorable indicators to track progress in PAR and eventually measure its impact on service delivery.

- Regulatory reform in the energy and mining sector. Modern Mineral and Hydrocarbon Laws were adopted in 2005, although shortcomings with the latter still need to be addressed. The 2005 amendments to the Income Tax Law have created a more attractive fiscal regime for the sector. The government has also committed to good governance, including by: (i) adopting regulations and model contracts; (ii) establishing an International Advisory Council to review transactions; (iii) using the services of an international firm to build the cadastre and grant licenses; and (iv) implementing the principles of the Extractive Industries Transparency Initiative (EITI). However, implementing these commitments and attracting private investment to the sector remain a major challenge.

- Transparency and accountability for human development outcomes. The Ministry of Public Health (MoPH) continued to strengthen its stewardship role, deepen its administrative reform program, and make progress in implementing the BPHS in the provinces. Progress in education has been significant since 2001, notwithstanding weak institutional capacity and frequent changes in political leadership. The authorities have recently drafted a five-year strategic plan for education, finalized the certification of the teacher payroll, and initiated the decentralization of decision-making down to the school level (as part of the IDA-funded Education Quality Improvement Program). However, there is a priority need to strengthen the focus on results by selecting a limited set of output indicators and tracking them carefully using household surveys. To increase transparency and accountability, publication of these results and other third-party assessments will be necessary. 


\section{Medium- To Long-Term Strategy For POVERTy Reduction}

\section{A. The PRSP Formulation Process}

19. In January 2006, the government's I-PRSP, the I-ANDS, was approved by the Cabinet, and presented to a Donor Conference. It was submitted to the IMF and World Bank in mid-March 2006, and, together with the Joint Staff Advisory Note, was discussed by the Boards in May and June 2006.

\section{Preparations toward Afghanistan's full PRSP - the ANDS - are progressing}

well. Progress was reported most recently to the Afghanistan Development Forum (ADF) in Kabul on April 29-30, 2007. The ANDS Strategic Work Plan - approved by the Oversight Committee of key Cabinet ministers that provides overall leadership for the ANDS process - sets out activities to develop the ANDS, including:

- Costing, Prioritization and Budgetary Integration: The government intends the ANDS to be a fully costed, prioritized and sequenced development strategy. To that end, an expenditure framework will be prepared based on final ANDS sector strategies. ${ }^{12}$ Given the breadth of coverage of the I-ANDS (and likely ANDS) pillars, prioritization and budgetary alignment will be a key challenge for developing sector strategies, and will require reconciling a "needs-based" approach with a "top-down" approach reflecting resource constraints. The MTFF should provide a useful tool for setting a resource envelope consistent with the government's fiscal objectives. Robust reporting by the government and international partners, and better coordination, will be crucial for ensuring that the use of donor contributions and scarce government resources are aligned.

- Consultation Process: While I-ANDS preparation involved broad consultations, the ANDS will be strengthened by more in-depth consultations. In 2006, the ANDS Secretariat conducted public awareness campaigns in 27 provinces. Lessons from the pilot provincial consultations conducted in April 2007 will feed into the 34 main provincial consultations to be completed by September 2007.

- Poverty Data and Analysis: The authorities are also working to address the severe poverty data limitations. While the 2005 NRVA enabled the first poverty analysis for Afghanistan, the authorities considered the limited sampling during summer to be a major weakness. Therefore, the poverty analysis in the ANDS will also be informed by an update of the 2005 NRVA, conducted in early 2007. The World Bank is providing analytical and technical support to the poverty diagnostic work.

\footnotetext{
${ }^{12}$ At end-April 2007, 43 ministry/agency draft strategies had been prepared.
} 
21. The authorities aim to complete the ANDS by early to mid-2008, with a view to presenting it at next year's ADF. While achievable, this timeline is ambitious given the challenge of integrating it into the budget formulation and execution process (for 2008/09), and ongoing efforts to institutionalize ANDS processes.

\section{B. Medium- to Long-Term Macroeconomic Outlook ${ }^{13}$}

22. Real GDP growth is projected to converge toward 4.5 percent a year by $2017 / 18$ (Table A9). In the very near term, robust GDP growth will reflect the expected recovery in agriculture after the 2006/07 drought, as well as continued strong contributions from services and construction on the back of the mostly donor-financed reconstruction effort. ${ }^{14}$ Continued, but more moderate, growth over the medium to longer term is expected to be underpinned by: (i) a gradual improvement in security and continued macroeconomic stability; (ii) institutional and financial sector reforms, including improved bank supervision, further development of monetary policy instruments and establishment of a capital market; (iii) increased investment in infrastructure; and (iv) an increasing role for the private sector over the medium to longer term, including in mining, energy, and agribusiness. ${ }^{15}$ On this basis, real GDP growth is expected to remain strong, but to taper-off to a long-term level of 4.5 percent per annum by $2017 / 18 .{ }^{16}$ Annual real GDP growth is assumed to average 5.6 percent a year over the projection period (2007/08-2026/27).

\section{After an expected temporary pick-up to 6 percent in 2007/08 owing to higher food and transportation costs, inflation ${ }^{17}$ is expected to moderate to 5 percent per year for the remainder of the projection period. The nominal exchange rate is assumed to}

\footnotetext{
${ }^{13}$ The lack of historical data preclude a meaningful comparison with long-run averages, and the averages for the past five years are questionable given large distortions in the data (e.g., the impact of reconstruction and donor activity, and the temporary surge in inflation associated with the reaction to the currency exchange).

${ }^{14}$ The impact of the drought on agriculture dominates the pattern of near-term real GDP growth. (Non-opium agriculture represents around one-third of GDP.) In 2006/07, real GDP growth eased to 7.5 percent (from an average of 12.6 percent in the preceding three years) as the decline in agricultural production detracted from double-digit growth in construction and services. The expected rebound in agriculture in 2007/08 - in addition to sustained activity in construction and services - will push growth up to 13 percent in 2007/08. Thereafter, growth is assumed to revert to more normal levels.

${ }^{15}$ While agriculture dominates the economy and will remain critical for poverty reduction, it is unlikely to drive long-term growth rates even with planned improvements. Long-term growth will require significant investment in Afghanistan's weak human capacity. Public institutions need to be strengthened and economic governance improved to ensure that economic growth can be sustained and inclusive.

${ }^{16}$ The longer-term growth assumption is not out of line with the average growth rate of comparator countries. The 10-year average (1997-2006) of real GDP growth across the same comparator country group used to estimate exports of services is 4.9 percent (See Box 2 and refer to www.imf.org Enhanced Initiative for Heavily Indebted Poor Countries_-Debt Sustainability Analysis).

${ }^{17}$ As measured by the 12-month Kabul-based consumer price index.
} 
remain stable and the inflation differential between Afghanistan and its trading partnersestimated at 2 percent during the projection period — is assumed to be offset by productivity catch-up.

\section{Investment is forecast to moderate from its current exceptional levels (44.1 percent of GDP in 2006/07) to a more sustainable long-term level (about} 25.5 percent of GDP). In the short term, investment will continue to be underpinned by high levels of donor support for reconstruction and public investment (mainly in infrastructure). Given the uncertainties associated with security and governance, a conservative assumption has been made regarding the efficiency of investment. As a result, the projected long-run investment-to-GDP ratio of 25.5 percent is not expected to generate real GDP growth higher than 4.5 percent a year. Over the projection period, the large part of "public" investment currently conducted directly by donors outside the central government budget will be progressively incorporated within the government's budget. Private investment is projected to increase gradually from 10 percent in 2006/07 to 15.8 percent of GDP over the projection period and will offset in part the expected decline in public investment. Improved access to credit, including through micro-finance in rural areas and the development of a capital market, will help support private investment.

\section{Fiscal policy will be aimed at ensuring macroeconomic stability and sustainability together with the delivery of priority development expenditures.}

Continued improvements in revenue performance are expected to offset the decline in budget support grants, allowing the central government to contain its overall deficit (before HIPC assistance) to just under 2 percent of GDP over the projection period. Specifically:

- Central government revenues are expected to increase gradually from 7 percent of GDP in 2006/07 to 12.7 percent of GDP in 2026/27, while grants to the budget are assumed to decline by half from the current level of around 10 percent of GDP. ${ }^{18}$ Taxes on international trade would continue to play a dominant role over the short to medium term, although their relative contribution will decline gradually as a broad-based consumption tax is expected to gain importance as administrative capacity improves.

- Central government expenditures would peak at 22 percent of GDP in 2010/11 before easing to about 19.6 percent of GDP by 2026/27. Operating expenditures are assumed to grow by 10 percent per year to allow for donor-financed current expenditures being gradually transferred onto the budget. Over the longer term, security-related expenditures are expected to decline from their current share of nearly 50 percent of the

\footnotetext{
${ }^{18}$ The high growth rate of revenue and grants in 2007/08 (Table A9) is consistent with budget approved by Parliament and is predicated on significant new security-related grants to the operating budget in addition to: (i) a pick up in development budget execution, which is largely grant-financed; and (ii) continued improvements in revenue performance.
} 
operating budget, and the relative wage structure will be kept in balance by donor restraint in the security sector and Pay and Grading $(\mathrm{P} \& \mathrm{G})$ reform in the civil service.

- As the government takes on investments currently funded by donors and short-term priorities are driven by reconstruction and security needs, development expenditures are expected to increase to about 11.5 percent of GDP by 2010/11. This ratio is expected to decline gradually as security stabilizes, averaging just over 10 percent for the remainder of the projection period. Nonetheless, donors are expected to play an important role in the short to medium term, with donor-financed off-budget expenditures exceeding direct budget support until about 2012/13. ${ }^{19}$

- Over the medium term, fiscal sustainability will be measured by whether, and when, domestic revenues cover operating expenses - a principle set out in the government's PRGF-supported program. The baseline scenario envisages the government meeting this objective by $2012 / 13$. However, the government will need to resist emerging political pressures that could pose a risk to their revenue targets. Longer-term sustainability will entail the government steadily decreasing reliance on overall external financing.

\section{External grants are expected to remain the predominant form of financing over} the projection period. This will be essential for the government to be able to finance its poverty reduction strategy in a fiscally sustainable way. However, as the economy continues to grow and the revenue base expands, the need for total external financing is expected to ease. Grants would decline significantly as a percentage of GDP (from just under 44 percent in 2006/07 to around 7.5 percent in 2026/27), and the share of debt financing would increase gradually over the projection period. The terms of new borrowing (largely from multilateral creditors) are expected to remain highly concessional in the short to medium termconsistent with the PRGF arrangement—but, after the completion point, it is likely that some borrowing will be on somewhat less concessional terms.

\section{Consistent with the assumed path of fiscal policy and availability of official financing, the external current account deficit (excluding transfers) is projected to decline steadily from over 45 percent of GDP in 2006/07 to about 10.5 percent in} 2026/27. As total investment declines in parallel with public investment, imports are expected to trend toward a more sustainable level, averaging just above 30 percent of GDP in the second half of the projection period compared to over 70.4 percent of GDP in 2006/07. The predictability of imports, however, is affected heavily by uncertainties surrounding the level of donor activities. At the same time, officially-recorded exports are expected to get a boost from an increasingly export-oriented private sector. However, given the low base of

\footnotetext{
${ }^{19}$ Donors are spending outside the budget process in many sectors, including agriculture, infrastructure, education, health and counternarcotics. Security-related grants are expected to decline more rapidly as the country stabilizes.
} 
official exports, it will be some years before they can provide a solid source of foreign exchange earnings.

28. Given the exceptionally difficult challenges facing Afghanistan, the macroeconomic projections are subject to significant uncertainties and risks. The evolution of the fragile security situation, weak governance and the counternarcotics effort will have a significant bearing on future macroeconomic conditions. Together with uncertainties surrounding the level of donor activities, the government's capacity to absorb those activities within the budget and the pace of the private sector's response, these issues underscore the risks to maintaining a rapid rate of growth. Afghanistan's heavy dependence on external grants - currently the main driver of domestic absorption - also leaves macroeconomic growth and stability vulnerable to faster than anticipated cutbacks in grants. If not reversed, the recent loss of momentum in tax and customs administration, and revenue policy more generally could pose a risk to the government's revenue objectives, and the longer-term ability to deliver pro-poor and pro-growth expenditures in a fiscally sustainable way. The sensitivity analysis in Section IV.F. therefore considers, among other factors, the impact of lower growth and less grant financing (or weaker-than-projected revenue performance). The broader growth and development agenda also remains subject to a number of other exogenous risk factors. ${ }^{20}$

\section{The Reform Agenda}

29. The I-ANDS underscores the government's commitment to maintaining macroeconomic stability and addressing poverty. Reflecting the three main pillars of the I-ANDS, the reform agenda focuses on creating an environment conducive to private sector-led equitable economic growth, while progressively eliminating the drug economy. In developing the ANDS, the government plans to incorporate cross-cutting themes of gender, counternarcotics, anti-corruption and environmental protection into their reform strategy.

\section{Recognizing the critical role of security, the government has adopted a special} MDG on enhancing security (one of the three I-ANDS pillars). This focuses on plans to train the new ANP, establish an auxiliary police force, and accelerate ANA recruitment, which has important medium-term fiscal implications. To improve the judicial system and ensure its independence, the strategy also includes efforts to rebuild the administration of juvenile justice, prison, and law enforcement systems. The government also seeks to build human rights institutions and capacity, raise awareness, and develop societal consensus around human rights issues.

\footnotetext{
${ }^{20}$ Public expectations are high, as is the risk that the government will not be able to deliver on its promises and lose credibility. The next Presidential elections in 2009 may exacerbate these tensions.
} 


\section{The government is committed to implementing a macroeconomic framework} anchored in fiscal discipline, which is reflected in the sustained performance under the IMF's PRGF arrangement. A key challenge will be aligning the budget with the ANDS, improving the realism of the development budget, and coordinating external aid. In order to enhance the budget as a core policy tool and channel more external aid through the budget, the government is committed to: (i) refining the harmonized donor reporting format to maximize donor responses and inform the next annual core budget process; (ii) presenting the next annual budget according to sector priorities using the program budgeting pilots, where possible, and stringent project selection; (iii) undertaking the necessary Treasury reforms to strengthen expenditure tracking; and (iv) continuing reforms to improve the effectiveness of budget implementation (as set out in $\mid 18$ ).

\section{The government plans to strengthen its debt management capacity to} complement plans to align the ANDS reform agenda with a sustainable MTFF. In this regard, the government is committed to securing mainly grant financing from donors and undertaking only limited borrowing on highly concessional terms. The Ministry of Finance also plans to improve the tracking and monitoring of the government's external debt obligations by: (i) initiating quarterly external debt reporting, possibly later this year; and (ii) acquiring and installing a modern debt management and reporting system. The latter will likely require the financial and technical support of donors.

\section{The government has placed high priority on implementing its new PAR strategy} as a key component of the I-ANDS and the anti-corruption strategy. Central to this strategy will be P\&G reform, due to start implementation this year and under which: (i) administrative structures will be reviewed; (ii) jobs will be re-graded with clear job descriptions; and (iii) staff that meet merit-based criteria will be placed on a new pay scale, at higher and less compressed levels (hence improving incentives to join and stay in the civil service and perform). Moreover, an action plan adopted in April 2007 to strengthen merit-based recruitment processes will be implemented. Other initiatives - e.g., for sub-national administration and pensions-will complement the P\&G policy.

34. The current pension scheme is not fiscally sustainable and its administration is unsatisfactory. Accordingly, the government plans to reform the Pension Department and establish a Pension Policy Unit, adopt an affordable civil service pension policy, and modernize its pension administration.

\section{The government intends to advance its Public Financial Management (PFM)} reforms and improve adherence to fiduciary standards as part of its anti-corruption strategy. The Treasury will further enhance the financial control framework, cash management will be upgraded and the work program of the MoF's Internal Audit Department will be scaled up. Financial reporting will benefit from program budgeting pilots and the roll-out of AFMIS over the next few years should provide line ministries with full access to the financial management system and improve capacity for reporting. The 
government intends to revise the Audit Law, in line with the Constitution and the PFEM Law, to clarify the role of external audit and its responsibility to respond to audit findings. The Control and Audit Office (CAO) is committed to publishing its annual audit report. At the same time, in partnership with the CAO and donors, the capacity of the Parliament's Finance and Budget Committee will be developed. In addition, the Procurement Policy Unit will draft a suite of standard bidding documents for the procurement of goods and will disseminate them. It will also develop a procurement code of conduct to improve transparency and implement the decentralization and capacity building plan. The monitoring system and regulations for disclosure of information will be improved.

\section{The government is committed to supporting private-sector led growth within a} sound legal and regulatory environment. Recently, a Special Investment Reform Committee was set up to review Afghanistan's performance against the Doing Business Indicators and develop a strategy to improve it. With respect to the legal framework, the government is committed to simplifying legislation, regulations, and procedures related to investment, as well as administrative processes to facilitate business development. The government will continue implementing its industrial park strategy. The government's plans to strengthen the banking system's regulatory and supervisory framework, consistent with the Core Basle Principles, should help foster a sustainable expansion of private sector activities.

37. The government will create a framework conducive to competitiveness and efficient markets in agriculture. The government's strategy focuses on perennial horticulture, livestock production, and food security and calls for the establishment of the legal, institutional, regulatory, and incentive framework necessary to increase agricultural production and productivity and encourage the development of agriculture-based industries. In the critical area of water management, the recently formed Supreme Council for Water Affairs Management will finalize a water sector strategy. The government is also committed to reforming the system of land registration and land dispute settlement.

38. Another important reform area will be to ensure that underground resources, and the proceeds accruing to the government, are used efficiently and effectively. Looking ahead, the reform strategy will consist of: (i) amending the Hydrocarbons Law to address identified shortcomings; (ii) implementing the new laws; and (iii) reforming the Ministry of Mines from a vertically-integrated extractive industry conglomerate to a regulatory ministry. In addition to implementing financial disclosure requirements in the Mining and Hydrocarbon Laws, implementing EITI principles will require regularizing informal mining activities, and timely and systematic accounting and record-keeping of mineral sector revenues in the Ministries of Mining and Finance.

39. To enhance human development and make progress towards the MDGs, the government plans to undertake reforms in the education and health sectors. 
- The government will finalize and prioritize its strategic plan to deliver on its education sector objectives to: (i) increase access to education for all by providing adequate infrastructure throughout the country; (ii) improve the quality of education by reforming school curricula and training teachers with an emphasis on female teachers; and (iii) improve overall service delivery through major public administration reforms and capacity building program for policy makers, education administration staff, teachers, and communities. A higher education law will be submitted to Parliament to increase the autonomy of public universities. The Ministry of Education's monitoring and evaluation system (Education Management Information System) will be strengthened to make it more relevant for planning and management purposes, and to increase transparency and accountability.

- In order to further improve access to health services, particularly in remote areas, the government intends to establish sub-centers and mobile teams. It also plans to explore demand-side activities such as conditional cash transfers to increase utilization of existing services such as skilled birth attendance. The MoPH is committed to further strengthening the results focus in the sector by selecting a limited set of output indicators and tracking them carefully using household surveys. It will publicize third-party assessments of the BPHS to increase transparency and accountability. Finally, the government will implement its National HIV/AIDS strategy.

\section{Possible Assistance Under the HIPC Initiative and DebT Sustainability ANALYSIS}

\section{A. Debt Reconciliation Status}

40. The DSA presented below was prepared jointly by the authorities and the staffs of IDA and the IMF. It is based on loan-by-loan data, provided by the authorities and creditors, for public and publicly-guaranteed debt outstanding and disbursed as of March 20, 2006. The reconciliation, covering 100 percent of multilateral and bilateral debt, was completed in April 2007. ${ }^{21}$ However, given the protracted conflict in Afghanistan and consequent lack of documentation, there is a greater-than-usual likelihood of the existence of as yet unidentified debts.

\section{B. Structure of External Debt}

\section{Afghanistan's public and publicly-guaranteed external debt is estimated at} US\$11.9 billion in nominal terms as of March 20, 2006, prior to the application of traditional debt relief mechanisms (Tables 4 and A1, and Figure 1). This corresponds to US\$11.6 billion in net present value (NPV) terms. Official bilateral creditors account for the

\footnotetext{
${ }^{21}$ Disputed claims (see Box 2) have been excluded from this analysis.
} 
vast majority -95.3 percent — of the total outstanding debt stock, of which the Russian Federation was the key creditor, representing 93.2 percent of total external debt (before the application of an up-front 80 percent discount on its debt disbursed before 1992). The remaining bilateral claims are held by two other Paris Club creditors-United States (0.9 percent) and Germany (0.4 percent) — and several non-Paris Club creditors ( 0.8 percent). Multilateral creditors include IDA and the Asian Development Bank (AsDB), representing 2.5 percent and 2.1 percent of Afghanistan's debt, respectively. As of March 20, 2006, there was no outstanding debt to the IMF or undisputed claims to commercial creditors.

Table 4. External Debt as of March 20, 2006

(In units indicated)

\begin{tabular}{lrrr}
\hline & In US\$ million & $\begin{array}{r}\text { Percent } \\
\text { of total }\end{array}$ \\
\cline { 2 - 2 } Total & $11,939.4$ & 100.0 \\
Bilateral & $11,382.1$ & 95.3 \\
Paris Club & $11,283.5$ & 94.5 \\
Russian Federation 1/ & $11,127.9$ & 93.2 \\
United States & 111.7 & 0.9 \\
Germany & 43.9 & 0.4 \\
Non-Paris Club & 98.6 & 0.8 \\
Multilateral & 557.3 & 4.7 \\
Of which: IDA & 300.8 & 2.5 \\
$\quad$ Asian Development Bank & 254.6 & 2.1 \\
Memorandum items: & & \\
NPV of debt after traditional debt relief 2/ & $1,120.0$ & $\ldots$ \\
(in percent of exports) 3/ & 306.2 & $\ldots$ \\
\hline
\end{tabular}

Sources: Afghan authorities and staff estimates.

1/ Before up-front 80 percent discount on Russian debt.

2/ After up-front 80 percent discount on Russian debt prior to the application of traditional debt relief.

3/ Calculated using a backward-looking three-year average of exports of goods and services; excluding transit goods.

\section{Afghanistan has regularized its debts to multilateral and Paris Club creditors,} and has opened negotiations with non-Paris Club bilateral creditors (Box 1). Arrears to the AsDB and IDA were cleared in 2002 and 2003, respectively. Arrears to OFID (US\$1.9 million) are expected to be regularized after approval of the decision point. US\$11.3 billion of debt to Paris Club creditors was regularized in the context of the July 2006 rescheduling agreement. The Minister of Finance wrote to non-Paris Club bilateral creditors in April 2007, commencing a dialogue on the restructuring of these claims, which total just under US\$100 million. 


\section{Box 1. External Arrears Clearance}

During the protracted period of conflict, Afghanistan accumulated a significant amount of arrears, mostly to bilateral creditors. The authorities have regularized relations with Paris Club bilateral creditors and all multilateral creditors, and are working to open negotiations with other creditors.

- On July 19, 2006, Afghanistan's three Paris Club creditors - Germany, the Russian Federation and the United States - agreed on a substantial debt reduction package, following IMF approval of the PRGF arrangement in June 2006. The bilateral agreements with the United States and Germany were signed in September 2006 and April 2007, respectively. The remaining bilateral agreement with Russia is expected to be finalized shortly.

- $\quad$ The Paris Club agreement covered US\$11.3 billion of official development assistance (ODA) and non-ODA debts, including arrears and late interest due as of March 31, 2006, as well as maturities falling due between April 2006 and March 2009.

- Debts were restructured on "Naples terms": (i) ODA credits were rescheduled over 40 years, with a 16 year grace period, at interest rates as least as favorable as the original rates; and (ii) 67 percent of non-ODA credits were cancelled and the remainder rescheduled over 23 years, with a 6-year grace period, at market interest rates. On an exceptional basis, the agreement also deferred 100 percent of the moratorium interest due over the consolidation period, to be repaid after October 2011.

- $\quad$ After the upfront 80 percent discount applied to debts to the Russian Federation, the restructuring under "Naples terms" reduced Afghanistan's obligations to Paris Club creditors to less than US\$0.9 billion.

- Afghanistan is working to regularize relations with non-Paris Club official bilateral creditors. Some debts have already been forgiven (e.g., the Slovak Republic in late 2005). The authorities wrote to all other known creditors in April 2007, commencing a dialogue on the possible terms of restructuring and with a view to seeking comparable treatment in line with the Paris Club rescheduling agreement.

- Afghanistan has cleared its arrears with all its multilateral creditors, with the exception of the OPEC Fund for International Development (OFID).

- In November 2002, Afghanistan cleared US\$17.1 million in arrears with the Asian Development Bank, using funds from the UK Department for International Development (DFID).

- In February 2003, Afghanistan cleared US\$28.2 million in arrears to IDA and about SDR 8.0 million in arrears to the IMF. Arrears to IDA and the IMF were cleared using funds from bilateral donors.

- $\quad$ The Afghan authorities have been in a close dialogue with the OFID, with a view to regularizing US\$1.9 million in arrears. OFID wrote to the authorities in late May 2007 and committed to address the arrears issue, with the details to be resolved after the decision point.

- $\quad$ Some relatively small amounts (less than 1 percent of total external debt) to commercial creditors and one bilateral creditor remain in dispute. The authorities are working to clarify their obligations in this respect. 


\section{Possible Assistance Under the HIPC Initiative}

\section{Afghanistan's debt in NPV terms is estimated at US\$1,120.0 million, after the} full application of traditional debt relief mechanisms (as of March 20, 2006) (Table 5). ${ }^{22}$ This is equivalent to 306.2 percent of exports of goods and services, using staff estimates of exports of services (Box 2). Given that the NPV of debt-to-exports ratio is above the 150 percent HIPC threshold, Afghanistan qualifies for debt relief under the HIPC Initiative's export window.

\section{Table 5: HIPC Initiative Assistance Under a Proportional Burden-Sharing Approach Net Present Value of Debt as of March 20, 2006 1/}

\begin{tabular}{lcc}
\multicolumn{2}{c}{ (In millions of U.S. dollars, unless otherwise indicated) } \\
\hline & $\begin{array}{c}\text { Debt Outstanding } \\
\text { Pre-HIPC }\end{array}$ & $\begin{array}{c}\text { Possible } \\
\text { HIPC Debt Relief }\end{array}$ \\
\cline { 2 - 3 } Total & $1,120.0$ & 571.4 \\
as percent of exports of goods and non-factor services & 306.2 & 156.2 \\
Bilateral 2/ & 855.3 & 436.3 \\
Paris Club: & 822.7 & 419.7 \\
$\quad$ Russian Federation 3/ & 737.2 & 376.1 \\
Germany & 13.6 & 7.0 \\
$\quad$ United States & 71.8 & 36.6 \\
Other Official Bilateral: & 32.6 & 16.6 \\
Multilateral & 264.7 & 135.1 \\
$\quad$ IDA & 147.5 & 75.2 \\
Asian Development Bank & 115.4 & 58.8 \\
OPEC Fund for International Development & 1.9 & 1.0 \\
Memorandum Items: & & $\ldots$
\end{tabular}

Sources: Afghan authorities; and IMF and World Bank staff estimates and projections.

1/ The proportional burden sharing approach is described in "HIPC Initiative-Estimated Costs and Burden Sharing Approaches" (July 7, 1997 and IDA/SEC M 97-306, July 7, 1997).

2/ After a hypothetical stock-of-debt operation on Naples terms (March 20, 2006) and comparable treatment by other official bilateral creditors. Includes all official bilateral creditors.

3/ Includes an up-front 80 percent discount on Russian debt disbursed before 1992.

4/ Based on the three-year average of exports of goods and services (backward-looking average, i.e., 2003/04-2005/06); excluding transit goods.

\footnotetext{
${ }^{22}$ This also reflects the up-front 80 percent discount on Russian Federation debt disbursed before 1992.
} 


\section{Box 2. Staff Estimation of Afghanistan's Exports of Services ${ }^{1 /}$}

The absence of reliable source data on Afghanistan's exports of services necessitated that the staffs impute the value of exports of services for the purposes of assessing Afghanistan's qualification for debt relief under the HIPC Initiative. Accordingly, the staffs estimated Afghanistan's exports of services based on three principles:

- Identifying a group of comparator countries that: (i) are PRGF-eligible and meet the World Bank's low-income country (LIC) classification; and (ii) share Afghanistan's key characteristics of being landlocked and either post-conflict or located within the central Asia region;

- Calculating a benchmark ratio of total service exports to merchandise exports in those comparator countries (31.4 percent), averaged over the period 1980-2005; and

- Applying that benchmark ratio to Afghanistan's official merchandise export data as reported by the Central Statistics Office.

This methodology produced the following results:

Islamic Republic of Afghanistan: Estimates of Services Receipts

\begin{tabular}{|c|c|c|c|c|c|c|}
\hline & $\begin{array}{c}\text { Services } \\
\text { Ratio 2/ }\end{array}$ & $\begin{array}{c}2001 / 02 \\
1380\end{array}$ & $\begin{array}{c}2002 / 03 \\
1381\end{array}$ & $\begin{array}{c}2003 / 04 \\
1382\end{array}$ & $\begin{array}{c}2004 / 05 \\
1383\end{array}$ & $\begin{array}{c}2005 / 06 \\
1384\end{array}$ \\
\hline & (percent) & \multicolumn{5}{|c|}{ (in millions of US dollars) } \\
\hline Merchandise Exports 3/ & $\ldots$ & 68 & 100 & 144 & 305 & 386 \\
\hline \multicolumn{7}{|l|}{ Services Receipts } \\
\hline Comparator Group: Landlocked (post-conflict or regional) & 31 & 21 & 31 & 45 & 96 & 121 \\
\hline Total Exports of Goods \& Services & $\ldots$ & 90 & 132 & 189 & 401 & 507 \\
\hline
\end{tabular}

The Fund is committed to providing technical assistance to support the authorities' efforts to compile a comprehensive balance of payments (including services data). If, before reaching the completion point, there are revisions in the data (debt or economic) used in the decision point DSA calculations, a revised DSA will be prepared. Adjustments to the amount of HIPC debt relief will depend on the nature of data revisions (see footnote 31 of IMF Country Report No. 07/232 the Preliminary Document ${ }^{1 /}$ ).

1/ For more detail see Box 1 and Appendix II of the Preliminary Document (IMF Country Report No. 07/232, March 27, 2007 and IDA Report No 39093-AF, March 27, 2007), discussed by the IMF and World Bank Executive Boards on April 11 and 18, 2007, respectively.

2/ Comparator ratio derived from the IMF's Balance of Payments Yearbook (database) based on data covering 1980-2005.

3/ Data provided by Afghanistan's Central Statistics Office. 
44. A common reduction factor of 51.0 percent, translating into HIPC debt relief of US\$571.4 million (in NPV terms), would be required in order to reduce Afghanistan's NPV of debt-to-export ratio to 150 percent (Table 5). Under the proportional

burden-sharing approach, the contribution from bilateral creditors to HIPC debt relief would be US\$436.3 million (in NPV terms). In particular, the contribution from the Russian Federation would amount to US\$376.1 million (in NPV terms). The contribution from multilateral creditors would total US\$135.1 million (in NPV terms), including US\$75.2 million (in NPV terms) from IDA.

45. Assuming the time profile and modalities presented below, HIPC debt relief to Afghanistan could amount to about US\$1.3 billion of nominal debt service relief over time. The following assumptions were made in projecting the time profile of possible HIPC Initiative assistance:

- IDA would provide total assistance amounting to US\$75.2 million (in NPV terms). Immediately following the approval of the decision point by the Boards, IDA would begin to provide assistance in the form of debt-service reduction on debt outstanding and disbursed as of March 20, 2006.

- Full participation of the AsDB in the HIPC Initiative is assumed. The AsDB is assumed to start providing its share of debt relief under the proportional burden-sharing mechanism (US\$58.8 million in NPV terms) on similar terms as IDA upon the approval of the decision point document.

- OFID is assumed to provide debt-service reduction starting at the completion point, amounting to about US\$1.0 million in NPV terms, until its contributions meet the requirement under the Enhanced HIPC Initiative.

- Paris Club bilateral creditors are assumed to provide a flow rescheduling on Cologne terms (i.e., a 90 percent NPV reduction) after reaching the decision point, with delivery of the remaining required assistance at the completion point through a stock-of-debt operation. This is expected to translate into debt relief of US\$419.7 million in NPV terms.

- Non-Paris Club official bilateral creditors are assumed to provide comparable treatment.

46. Status of creditor participation. IDA and IMF staffs have initiated consultations with multilateral creditors and bilateral creditors. So far, IDA, OFID and Paris Club creditors 
have indicated their willingness to provide HIPC Initiative debt relief to Afghanistan (Table A11) ${ }^{23}$ These creditors account for 86.8 percent of total HIPC Initiative relief.

\section{Debt Sustainability Analysis ${ }^{24}$}

\section{The DSA presented in this section is based on the long-term macroeconomic} projections prepared in the context of the second review under the PRGF arrangement (Box 3 and Section III.B.). Compared to the preliminary document, the current macroeconomic framework includes a modest revision to short-term economic prospects, reflecting the incorporation of recent economic data and information about the 2007/08 budget. However, the assumptions underlying the medium and long-term macroeconomic framework are essentially unchanged. As in the preliminary document, the current framework rests on: (i) improved security and macroeconomic stability; (ii) continued implementation of structural reforms, including governance, institutional and financial sector reforms; (iii) increased investment in infrastructure; and (iv) an expanded role for the private sector in economic activity.

48. HIPC debt relief would produce a rapid and durable reduction in Afghanistan's NPV of debt-to-exports ratio (Table A5 and Figure 3). Assuming the unconditional delivery of HIPC assistance-i.e., the full amount of assistance estimated to reduce the NPV of debt-to-exports ratio to 150 percent at the reference date, without staggering assistance over the decision and completion points-Afghanistan's NPV of debt-to-exports ratio could fall from 150 percent as of March 20, 2006 to 110.5 percent in 2006/07, and 51.8 percent by $2025 / 26$. The sharp decline in the short-term reflects the recent vigorous export growth. The NPV of debt-to-exports ratio is expected to remain consistently below the HIPC threshold of 150 percent throughout the projection period. External debt service as a ratio of exports is also expected to decline sharply after the delivery of HIPC assistance, remaining around 3 percent in the second half of the projection period. ${ }^{25}$

\section{Based on the conditional delivery of HIPC assistance, the NPV of debt falls in} steps, reflecting the phased delivery of assistance. That is, the NPV of external debt is contingent upon reaching the different "debt relief" milestones (Paris Club agreement,

\footnotetext{
${ }^{23}$ OFID has agreed, in principle, to provide HIPC debt relief to Afghanistan. The AsDB is in the process of considering its participation in HIPC.

${ }^{24}$ This DSA utilizes the HIPC DSA methodology, the debt sustainability analysis based on the LIC DSA is presented in the Enhanced Initiative for Heavily Indebted Poor Countries—Debt Sustainability Analysis (refer to www.imf.org).

${ }^{25}$ The debt service-to-exports ratio, after HIPC assistance, increases sharply in 2009/10, reflecting the 2006 Paris Club agreement (namely a moratorium on debt service to Paris Club creditors during the interim period).
} 
decision point, and completion point). ${ }^{26}$ Starting in 2009/10, when Afghanistan is assumed to have reached the completion point and have received irrevocable debt relief, there are no differences between the conditional and unconditional scenarios.

\section{Box 3. Key Macroeconomic Assumptions Underlying the DSA}

Annual real GDP growth is expected to converge toward a long-term rate of 4.5 percent by 2017/18. Notwithstanding vigorous growth expected in the near-term, led by the rebound in agriculture and reconstruction activities, average real GDP growth over the projection period (2007/08-2026/27) will be about 5.6 percent.

CPI inflation is projected to increase to 6 percent per annum in 2006/07, but to converge to 5 percent from 2007/08 onwards.

Investment is expected to remain at exceptionally high levels in the short-term, driven by donor-supported reconstruction and public investment. Over the medium to longer run, investment is projected to decrease gradually from about 44.1 percent of GDP in 2006/07 to 25.5 percent of GDP by 2026/27.

Fiscal policy aims at delivering the government's spending priorities while supporting macroeconomic stability. Central government revenues are assumed to increase gradually from 7.0 percent of GDP in 2006/07 to 12.7 percent of GDP in 2026/27. Expenditures are assumed to peak at just over 22.0 percent of GDP in 2010/11, and then decrease gradually to about 19.6 percent of GDP by 2026/27. The central government overall deficit (before HIPC assistance) is projected to average just under 2 percent of GDP over the projection period.

External grants are expected to remain the predominant form of financing, but decreasing as a percentage of GDP from just under 44 percent in 2006/07 to around 7.5 percent in 2026/27.

Official loan financing is assumed to continue on strictly concessional terms, with an average grant element of 56 percent. After playing a subsidiary role in the short to medium term, debt financing gains prominence toward the end of the projection period.

The external current account deficit (excluding external grants) is projected to diminish gradually from over 45 percent of GDP in 2006/07 to 10.5 percent in 2026/27.

\section{E. Sensitivity Analysis}

\section{Four scenarios were conducted to test the sustainability of Afghanistan's} external debt after the full delivery of HIPC assistance (Table A6 and Figure 4). Under all these scenarios, Afghanistan's external debt indicators would be higher than in the baseline.

\footnotetext{
${ }^{26}$ Under the "traditional debt relief" scenario a stock-of-debt rescheduling under Naples terms is fully accounted for in the NPV of debt at the reference date (2005/06). In contrast, the NPV of debt under the "conditional HIPC debt relief" scenario is predicated on reaching the different "debt relief" milestones. Therefore, the NPV of debt under "conditional HIPC debt relief" may be higher than under "after traditional debt relief" (Table A4 and Figure 3).
} 
In particular, the NPV of debt-to-exports ratio would, over the medium term, remain above its 2006/07 level in all but one scenario, and would rise significantly in the long-run under the lower GDP growth scenario.

- The first scenario - under which interest rates are assumed to be 200 basis points higher than the baseline - highlights the sensitivity of projections to less favorable concessionality on new borrowing. This results in a sharp decline in the average grant element of new borrowing to 36 percent, from 56 percent in the baseline. Although Afghanistan's NPV of debt-to-exports ratio would continue to decline under this scenario (as, on average, 90 percent of financing needs are projected to be met by grants), by the end of the projection period it would be around 25-30 percentage points above the baseline scenario.

- The second scenario considers the sensitivity of projections to a greater reliance on debt, rather than grant, financing. Under this scenario, budgetary grants are permanently reduced by 1 percentage point of GDP starting in 2009/10. The resulting financing needs are met by a corresponding increase in borrowing, with an average grant element of around 53 percent over the projection period. Based on these assumptions, the NPV debt-to-exports ratio would increase to 123.3 percent by $2017 / 18$, but would then start to decline, reaching 108.3 percent by the end of the projection period. Compared to the baseline, this translates into a steady deterioration of the NPV of debt-to-exports ratio, from 5 percentage points higher in 2009/10 to 56.4 percentage points higher by $2025 / 26$. An equivalent shortfall below the projected increase in the revenue-to-GDP ratio would have a similar impact on Afghanistan's debt indicators.

- The third scenario considers the sensitivity of projections to lower export prices. Growth in export prices is assumed to be 15 percent (or around one standard deviation of the historical average) lower than in the baseline. Under this scenario, the NPV of debt-to-exports would decline from 110.5 percent in 2006/07 to 97.3 percent in 2011/12. Thereafter, the ratio is expected to start increasing, reaching 131.3 percent by 2025/26.

- The fourth scenario - considering the sensitivity of projections to lower GDP growthis particularly pertinent given risks to the growth outlook (\$28). It assumes that GDP growth is 1.5 percentage points lower than in the baseline scenario, and goes beyond a partial analysis, considering the feedback effects of correspondingly lower export receipts, foreign direct investment and government revenues. In the absence of fiscal adjustment, the financing gap is assumed to be met through additional borrowing. Under this scenario, the NPV of debt-to-exports ratio is expected to gradually decline to 104.2 percent by $2009 / 10$. Afterwards, this ratio is expected to increase steadily, reaching 213.8 percent by 2025/26, 162 percentage points higher than under the baseline scenario. This highlights the need for Afghanistan to maintain a robust level of economic growth and the importance of grant financing for the authorities to maintain fiscal sustainability. 


\section{F. MDRI and Possible Bilateral Assistance Beyond HIPC}

51. Afghanistan would qualify for MDRI debt relief from IDA upon reaching the completion point under the HIPC Initiative. MDRI debt relief would cover all outstanding debt disbursed from IDA prior to end-December 2003, and still outstanding at the completion point. Therefore, the amount of MRDI debt relief is contingent upon the timing of the completion point. For IDA, MDRI relief would start at the beginning of the quarter following the completion point. The IMF has no MDRI-eligible debt. ${ }^{27}$

\section{MDRI debt relief from IDA could amount to US\$37.6 million in nominal terms} (US\$14.3 million in NPV terms), assuming that Afghanistan reaches the completion point in July 2009 (Table A3). This would be in addition to the US\$1.3 billion to be provided under the HIPC Initiative, which includes US\$124.6 million from IDA.

53. Afghanistan's NPV of debt-to-exports ratio would decline slightly with the delivery of MDRI assistance. Assuming that Afghanistan reaches the completion point in July 2009, its NPV of debt-to-exports ratio would decline by 2 percentage points in 2009/10, compared to the conditional delivery of HIPC assistance. ${ }^{28}$

54. Paris Club creditors are expected to provide further relief after the completion point, having committed to cancel 100 percent of Afghanistan's debt following its successful implementation of the HIPC initiative process. This would amount to US\$403.0 million in NPV terms (Table A4).

\section{The Floating Completion Point}

\section{A. Triggers for the Floating Completion Point}

55. IMF and IDA staffs have reached understandings with the authorities on the completion point triggers (Box 4). Reflecting the views expressed by Executive Directors during the discussions of the preliminary HIPC document, the staffs have clarified with the authorities the scope, feasibility and monitoring of the triggers. The standard triggers on sustained macroeconomic management and implementation of a poverty reduction strategy would be complemented by measures focused on strengthening public institutions and improving economic governance to facilitate sustained and inclusive economic growth.

\footnotetext{
${ }^{27}$ Under the MDRI, the IMF committed to providing stock relief on outstanding debt disbursed prior to December 31, 2004, and still outstanding at the time of the completion point.

${ }^{28}$ This assumes that MDRI has no impact on Afghanistan's new borrowing over the projection period.
} 


\section{Box 4. Triggers for the Floating Completion Point}

\section{PRSP implementation}

- Prepare a full PRSP - the ANDS - through a participatory process and satisfactorily implement its actions for at least one year, as evidenced by an ANDS Annual Progress Report submitted by the government to the satisfaction of IDA and the IMF.

\section{Macroeconomic Management}

- Maintain macroeconomic stability as evidenced by satisfactory performance under the IMF PRGF-supported program.

\section{External Debt Management}

- Put in place and make operational a database system on external public and publicly-guaranteed debt; and publish at least three consecutive quarterly external debt reports in a timely manner (including data on the debt stock, and actual and projected debt service and disbursements).

\section{Public Expenditure Policy}

- Align public spending priorities with the priorities in the I-ANDS and, when completed, the ANDS. The matrix approach currently used to map the development budget against Compact benchmarks will be extended to all core development and operating budget expenditures in the year preceding the completion point.

- Design pension reform for public employees and military, reflecting the principles of fiscal sustainability, equity, and coordinated with overall public sector reform. Initiate implementation of a government-endorsed pension strategy with new pension regulations and reform of the Pension Department, including modernizing the system of processing and paying pensions.

- Restructure four core service delivery ministries (Agriculture, Education, Public Health, and Rural Development), reflecting common core functions and service delivery mechanisms. Progress in position grading - including competitive selection of civil servants with appointments and dismissals in full compliance with legal and due process requirements - as assessed by a third party.

\section{Public Financial Management}

- Produce a medium-term fiscal framework (consistent with the PRGF and ANDS priorities), in the year preceding the completion point, that includes: (i) an explicit target for the operating deficit (excluding grants) and a policy on non-grant financing; and (ii) a description of government policies and future policy options to support the projections, including basic tax policy analysis.

- Track poverty-related spending, over a period of at least six months preceding completion point, by reporting on government budget execution using a functional expenditure classification (at a more disaggregated level than currently used), supplemented with simple program classification and reporting in key ministries.

- Submit to parliament, for the year immediately preceding completion point: (i) the annual state (core) budget financial statement, prepared in line with the PFEM Law and audited according to international audit standards; and (ii) an annual report on the resolution of important findings identified by the external auditor.

\section{Business Environment and/or Economic Development}

- Develop and adopt regulations and guidelines for mining exploration licenses, quarry authorizations, exploitation licenses, and hydrocarbon exploration or service and development contracts. Establish a fully operational Hydrocarbon/Mining Cadastre to implement these regulations and guidelines.

\section{Human/Social Development}

- Improve transparency and accountability for service provision through publishing annually government and third-party data on the quantity and quality of services delivered in the health and education sectors. 
- The debt management trigger is intended to improve the availability of debt-related information and strengthen practices to manage the servicing and monitoring of debt. Together with efforts to ensure a sustainable fiscal policy through a strengthened MTFF, these triggers aim to help Afghanistan avoid accumulating an unsustainable debt burden in meeting its sizeable reconstruction and development needs.

- The trigger on aligning budgetary spending priorities (consistent with the fiscal objectives of the MTFF) and tracking spending outcomes will support the authorities' efforts to improve the prioritization, and effective delivery, of ANDS sector strategies. Moreover, effective alignment with the I-ANDS and forthcoming ANDS will require coordinating all core budget expenditures, to the extent possible, with known activities by development partners under the external budget.

- The triggers on pension reform and restructuring of core service delivery ministries support the authorities' ongoing PAR to transform a critical proportion of the civil service to one that adheres to regularized and transparent rules and procedures, with greater accountability for the use of public resources. The new pension reform strategy, including the pension regulations, will reflect principles of fiscal sustainability, equity, and coordination with the overall program of reforms in the public sector. This will contribute to the government's wider objective of improving the management of public expenditures.

- Other triggers - particularly those on external audit, hydrocarbon and mining regulations, and reporting on the delivery of health and education services - aim to promote accountability in the use of resources in a way that is both sustainable and helps support growth and reduce poverty.

\section{Based on the timetable for completing the ANDS and ongoing efforts to}

implement these measures, the government plans to meet the triggers within two years after the HIPC decision point. While feasible, this will require the government to sustain the momentum of its reform agenda.

\section{B. Monitoring the Floating Completion Point Triggers}

\section{IDA and IMF staffs will work together closely to monitor the completion point}

triggers, with each institution leading on issues where its staff has primary competence. IMF staff will take the lead in monitoring macroeconomic stability and anchoring fiscal sustainability in a strengthened MTFF. IDA staff will have principal responsibility for monitoring the triggers on pension reform, and public sector restructuring, and those pertaining to economic and social development. Also, IDA staff - in cooperation with IMF 
staff — will monitor progress in the preparation and implementation of the ANDS. IMF and IDA staffs will monitor jointly the triggers on public expenditure alignment and tracking, strengthening the external audit system, and improving debt management.

\section{The Use and Monitoring of Public Resources}

58. Securing the effective use of public resources for pro-poor growth is a foremost objective of the HIPC Initiative. Although the cash budget benefits of HIPC debt relief may be limited for Afghanistan, ${ }^{29}$ in the absence of the HIPC Initiative, the government would have to generate the necessary resources (or offsetting expenditure adjustments) to remain current in servicing its multilateral debts. This underscores the importance of ensuring the effective use of limited domestic revenues and considerable donor resources, which will require the capacity to adequately allocate, implement and monitor expenditure against pro-poor growth objectives. The trigger on using functional expenditure and simple program classifications should help support this. It will also require continued efforts to strengthen the programming, management and control of expenditure, and to improve service delivery in priority sectors.

59. Within this framework, ongoing technical assistance by the IMF and IDA in PFM will be key to improving expenditure tracking mechanisms. The aid effectiveness agenda - including better reporting of donor activities outside the national budget and, over time, greater use of national budget channels and systems to channel aid inflows-is also very important in this regard. The 2005 PFM Review addressed the design of specific mechanisms to enhance public financial management, recognizing that substantial progress had been made toward implementing a government expenditure classification system. A chart of accounts - covering all central government transactions - has been in place since March 2005 and has started to align the budgeting, accounting and reporting systems. However, the review identified that further work should be done to integrate the operating and development budgets. Subsequent advice from the IMF (April 2006) recommended the gradual introduction of a program structure, commencing with pilots to develop a new classification system in selected, better performing ministries for the 2007/08 budget. These ministries, to a greater or lesser extent, have already submitted integrated, program-based, budget presentations that were aligned to the I-ANDS sector strategies for the 2007/08 budget cycle. The authorities plan to review the progress in May/June 2007 and extended the pilots to agriculture and other ministries for the 2008/09 budget.

\footnotetext{
${ }^{29}$ The government had not been servicing its bilateral debts prior to the Paris Club agreement. However, the government has been servicing its debt to the AsDB and IDA since clearing its arrears.
} 
60. The administrative, functional and economic classifications already in place in Afghanistan provide a broadly adequate basis for tracking expenditure, including outlays deemed to be poverty-related. The functional classification of expenditures is currently only reported at an aggregate level. Although this provides an indication of the broad allocation of expenditures within a sector, it does not, for instance, allow for the identification of spending on primary and tertiary health services. It is expected that, by the time of the completion point, the authorities will have begun extending the functional classification to the second level of the Classification of the Functions of government in order to allow more detailed tracking of pro-poor spending against priorities identified in the ANDS.

61. A simple program classification would also provide additional information for more detailed policy analysis. The pilot program is currently underway in three priority Ministries - Education, Reconstruction and Rural Development, and Public Health. In addition to presenting an integrated budget according to a simple program structure, the Chart of Accounts has been modified for certain ministries to allow expenditures to be reported against programs in the AFMIS. ${ }^{30}$

\section{The resources made available by the HIPC Initiative prior to the completion} point - including from not having to resume servicing of bilateral debt previously in arrears - will enable the government to ensure expenditure levels in priority sectors. The I-ANDS identified eight priority sectors grouped under three pillars of activity (Box 5), and continued focus on these in the ANDS will necessitate greater prioritization. The breadth of expenditures covered reflects the short-term imperative of ensuring security to enable the effective delivery of longer run development objectives. Given that security expenditures are expected to be financed principally by external resources, HIPC relief from debt servicing could focus on aspects of economic and social development, such as health, education, infrastructure and rural development. In this regard, the costing of sector strategies and the strengthened MTFF to be completed later this year will help specify further the authorities' budgetary expenditure priorities.

\section{The Authorities' Views}

63. The authorities have emphasized that Afghanistan's external debt burden is unsustainably high and could further delay the country's economic and social reform agenda. They noted that Afghanistan is one of the poorest countries in the region and even among other HIPCs, with the population facing significant constraints on access to basic services such as education, health, and safe water. Protracted conflict and political instability have exacerbated the obstacles to social development and poverty reduction.

\footnotetext{
${ }^{30}$ This requires clearly defining programs and aligning ministerial structures, but does not necessarily require formulating, nor appropriating, the budget by programs.
} 


\section{Box 5. Medium-Term Expenditure Priorities}

The I-ANDS identified eight priority sectors spread across three pillars of activity. In most sectors, the full ANDS is likely to refine the existing I-ANDS, articulating how its goals will be achieved through a set of specific programs and projects that can be funded either through the budget or directly by donors.

Pillar One: Security

- Security: Establish a legitimate monopoly on force and law enforcement capable of providing a secure environment through reform of the Afghan National Army and Police.

Pillar Two: Governance, Rule of Law, and Human Rights

- Governance, Rule of Law, and Human Rights: Establish and strengthen government institutions at the central and sub-national levels. Reform the justice system with the aim of ensuring equal access to formal justice and judicial supervision of informal dispute resolution mechanisms.

Pillar Three: Economic and Social Development

- Infrastructure and Natural Resources: Implement investment programs to improve national roads network; energy and water; telecommunications; natural resources and mining; and urban development and housing.

- Education: Expand access to primary and secondary education; increase enrollment and retention rates; and strengthen the curriculum and quality of teachers.

- Health: Extend basic health services and essential hospital services; initiate communicable and noncommunicable disease control program; and strengthen health sector human resource management.

- Agriculture and Rural Development: Achieve pro-poor growth in rural areas by enhancing licit agricultural productivity; creating incentives for non-farm investment; developing rural infrastructure; and supporting access to financial services.

- Social Protection: Strengthen humanitarian and disaster response; and improve support to vulnerable (including women, demobilized soldiers, the disabled, and refugees and displaced persons).

- Economic Governance and Private Sector Development: Improve the management and accountability of public expenditures by strengthening the Medium-Term Fiscal Framework, improving revenue collection, and enhancing public finance management. Improve the investment climate by facilitating trade, reforming the regulatory system, and modernizing financial services and markets. 
64. The authorities highlighted that, with the support of Afghanistan's development partners, significant progress has been made since late 2001 in launching the reforms needed to achieve durable growth and poverty reduction. Nevertheless, this represents a fraction of what remains to be done. In the absence of HIPC debt relief, the regularization of relations with all creditors would represent a significant erosion of the government's limited capacity to deliver basic services and undertake essential reforms. Debt relief that could be available under the enhanced HIPC Initiative would help free resources for critical social and infrastructure programs, allowing the government to sustain its reconstruction efforts and improve access to education, health care, and critical infrastructure. This will be particularly important as, over the medium to longer-term, donor activities will be increasingly transferred onto the government's core budget.

\section{ISSUES FOR DISCUSSION}

65. This paper presents an assessment of the Islamic Republic of Afghanistan's qualification for assistance under the Enhanced Heavily Indebted Poor Countries (HIPC) Initiative. Executive Directors' views and guidance are sought in particular on the following issues:

- Qualification and decision point: Do Directors agree that Afghanistan qualifies for assistance under the HIPC Initiative - noting the use of staff estimates for exports of services - and do they recommend approval of the decision point?

- Amount of delivery of assistance: In order to reduce the NPV of debt-to-exports ratio to the HIPC Initiative threshold of 150 percent, the total amount of assistance under the HIPC Initiative is estimated at US\$571.4 million in NPV terms (Table 5). Of this amount, US\$75.2 million would be provided by IDA. Do Directors agree?

- Floating completion point: Do Directors agree that the HIPC floating completion point will be reached when the triggers in Box 4 have been met? Debt relief will be provided unconditionally only when the completion point triggers have been met and satisfactory assurances have been received of other creditors' participation under the enhanced HIPC Initiative. 
Figure 1. Islamic Republic of Afghanistan: Composition of Stock of External Debt as of March 20, 2006 by

Creditor Group

(Nominal stock: \$11.9 billion)

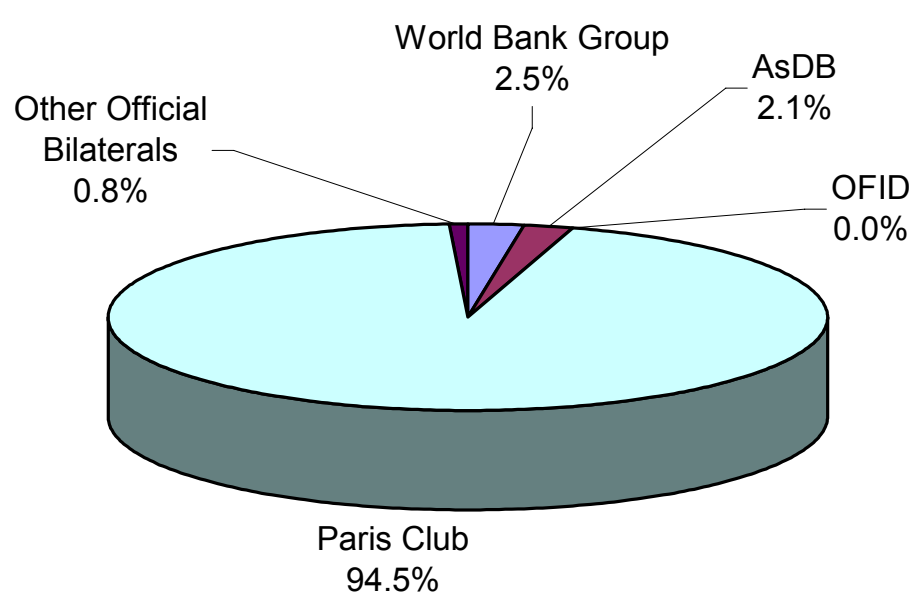

Sources: Afghan authorities; and staff estimates.

Figure 2. Islamic Republic of Afghanistan: Potential Costs of the HIPC Initiative by Creditor Group

(Total Estimated HIPC Enhanced Assistance: \$571.4 million; end-March 2006 NPV terms)

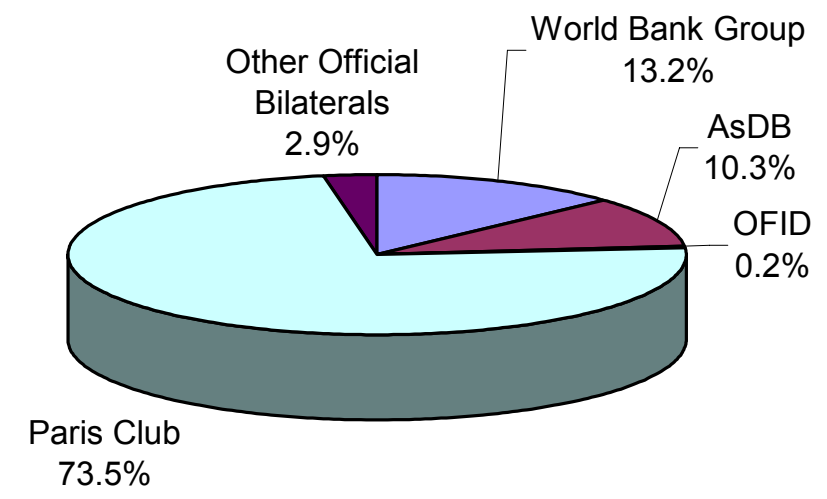

Sources: Afghan authorities; and staff estimates. 
Figure 3. Islamic Republic of Afghanistan: External Debt Sustainability Indicators, 2005/06-2025/26

NPV of Debt to Exports

(In percent of Exports)

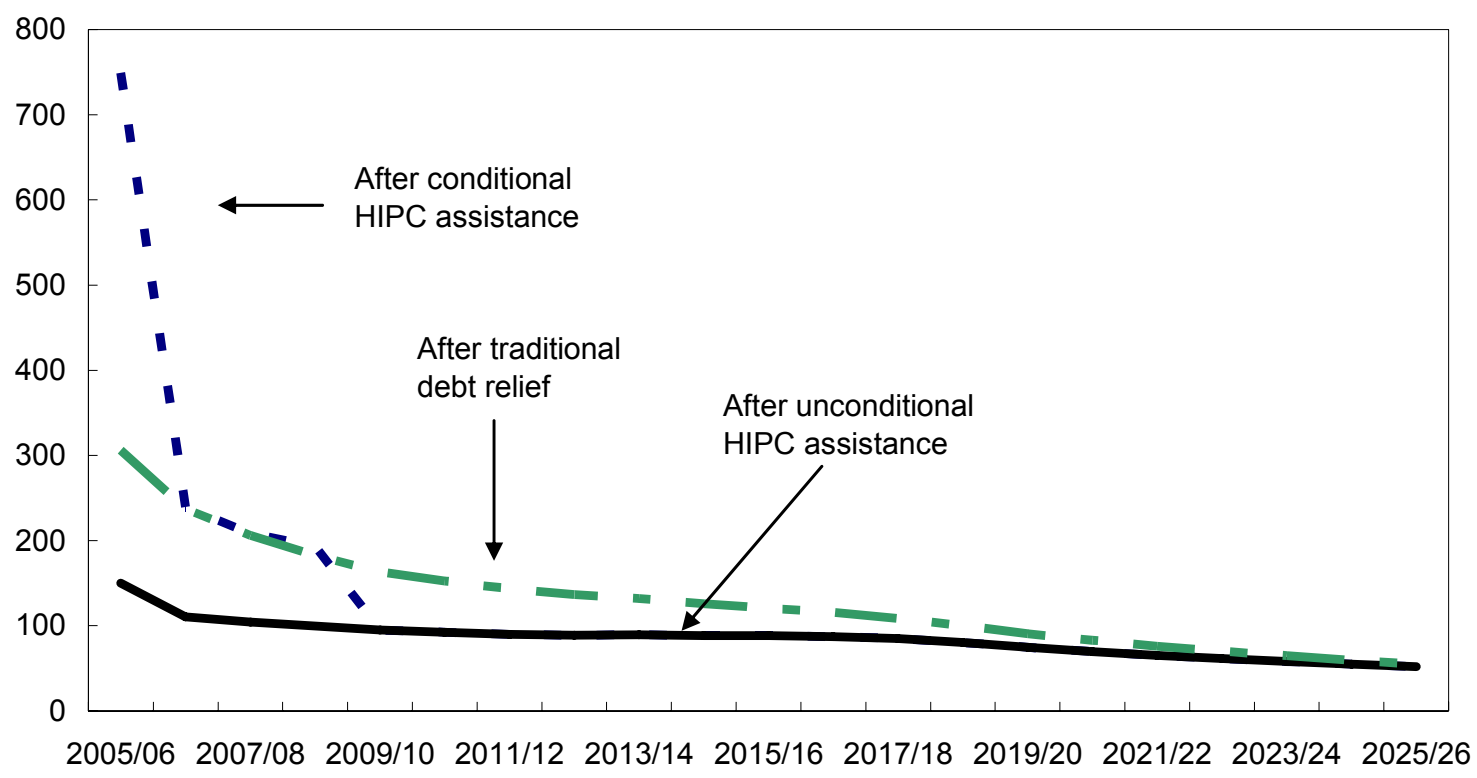

Debt Service to Exports

(In percent of Exports)

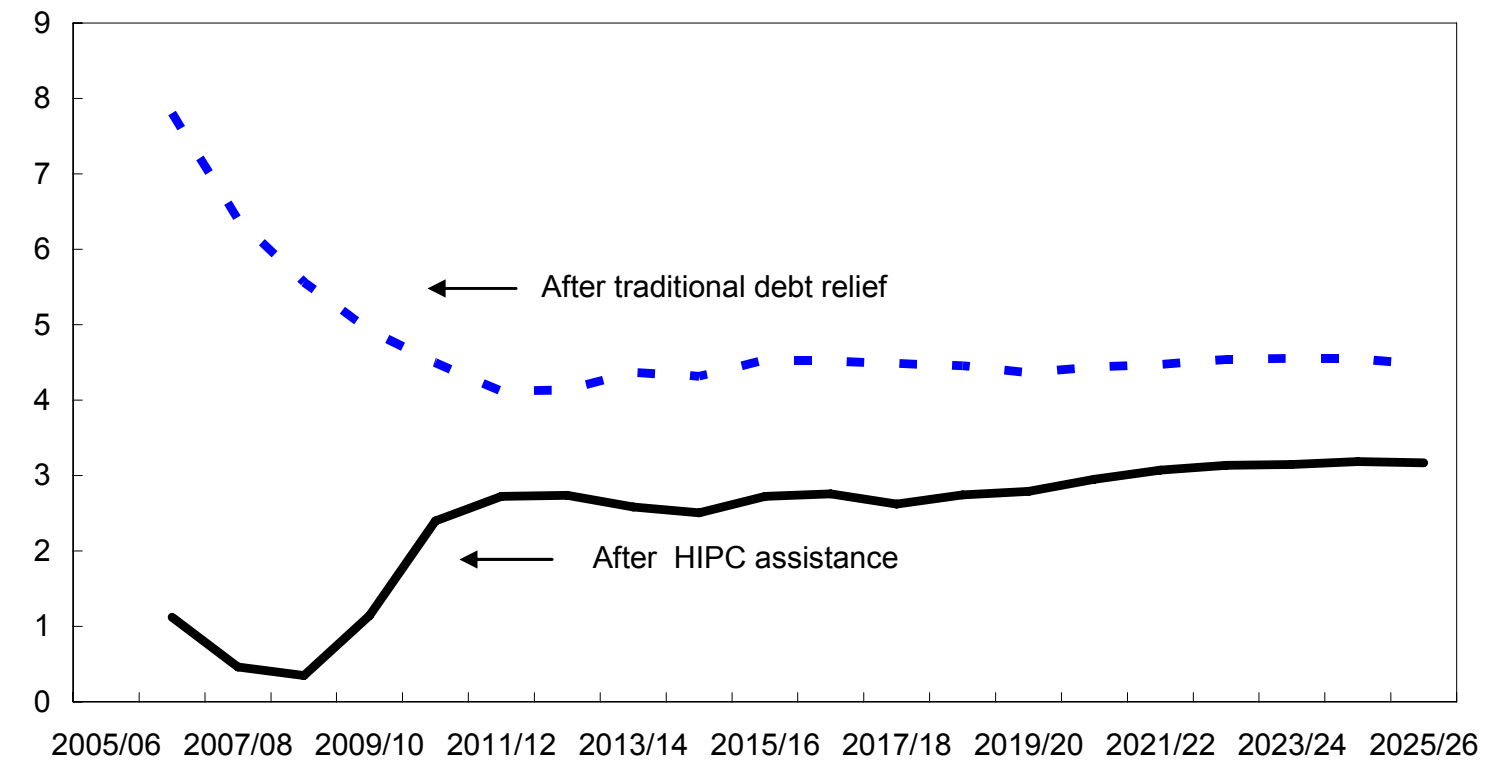

Sources: Afghan authorities; and staff estimates and projections. 
Figure 4. Islamic Republic of Afghanistan: Sensitivity Analysis, 2005/06-2025/26

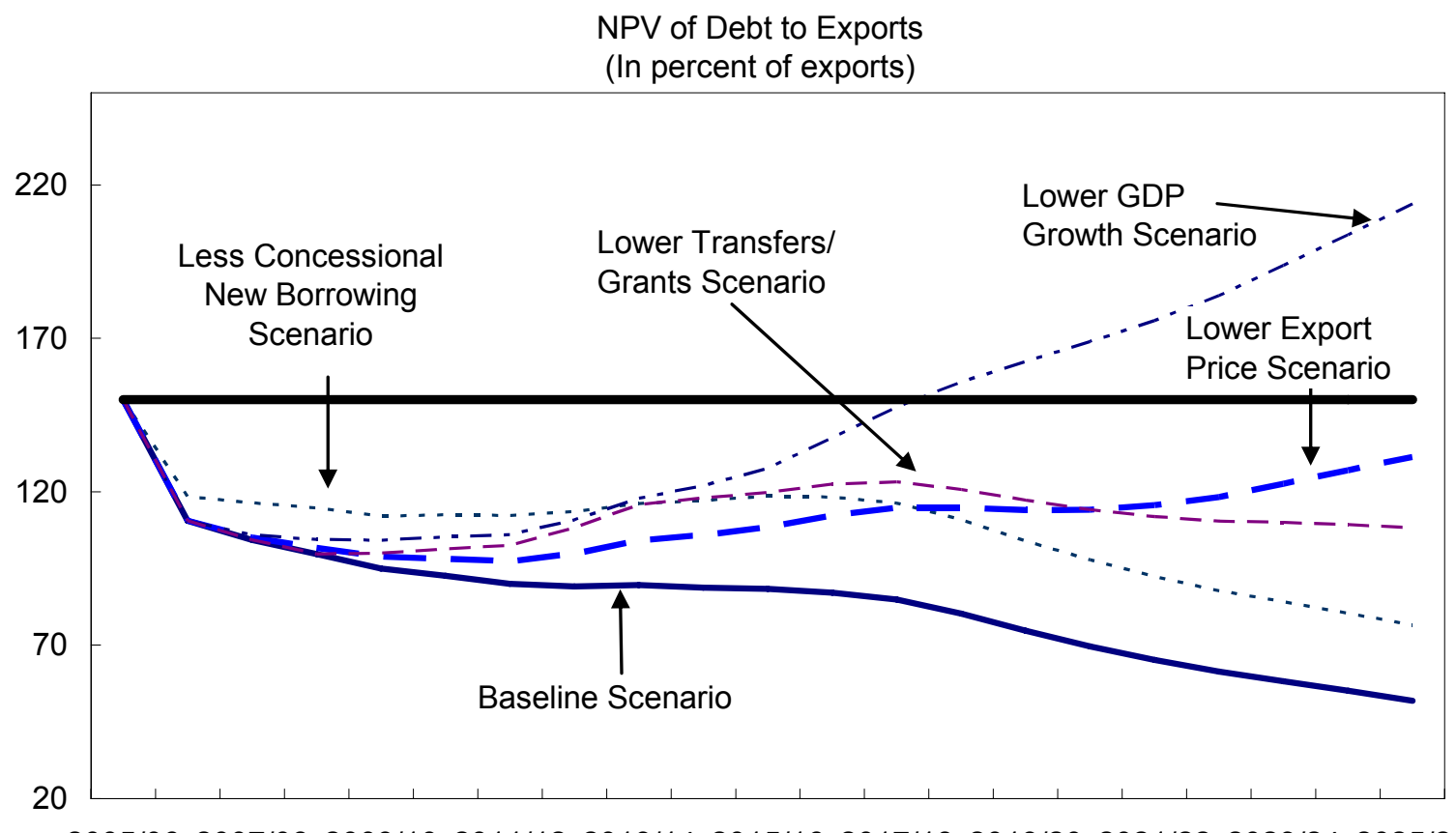

2005/06 2007/08 2009/10 2011/12 2013/14 2015/16 2017/18 2019/20 2023/20

Debt Service to Exports

(In percent of exports)

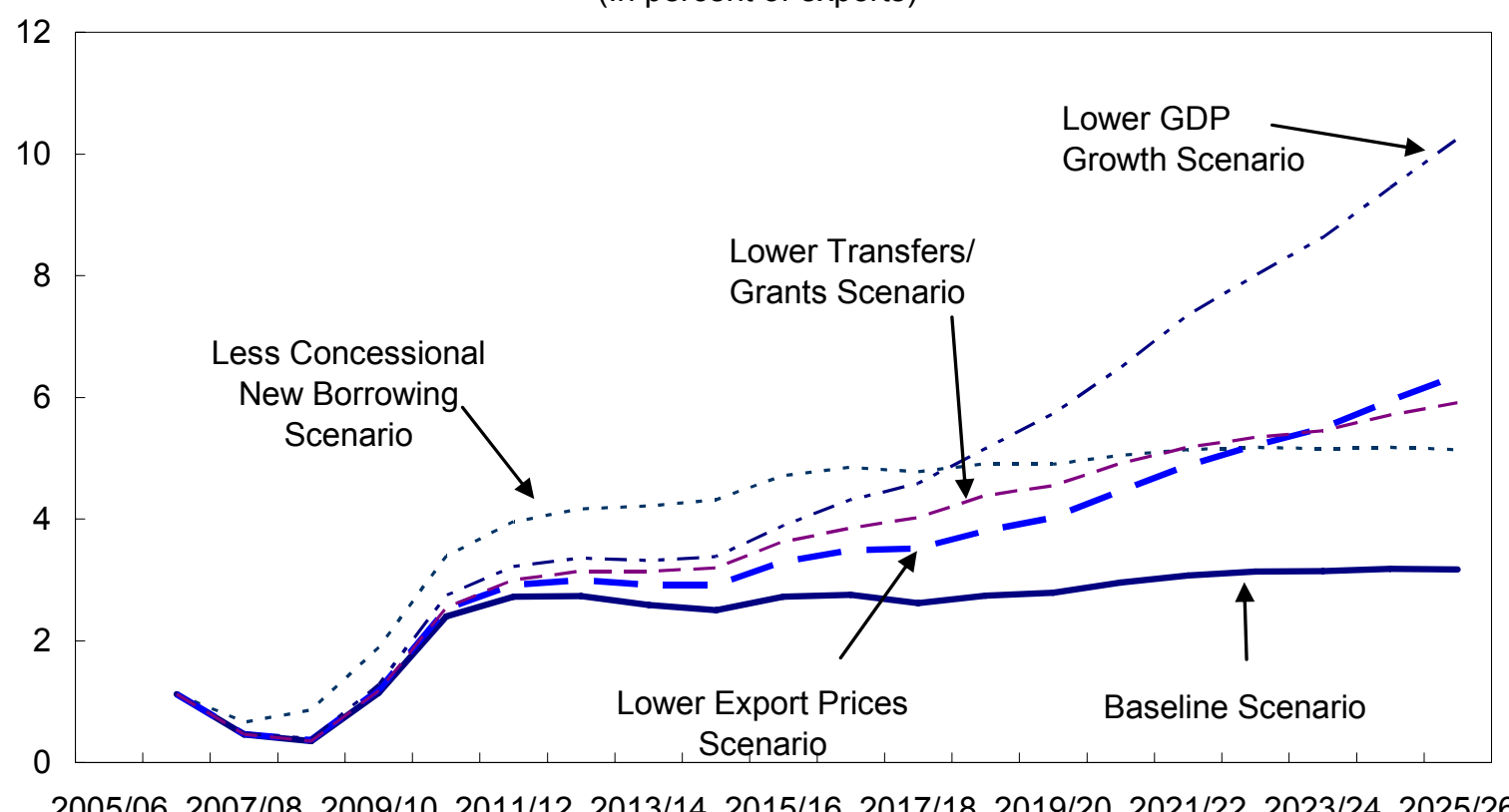

Sources: Afghan authorities; and staff estimates and projections. 


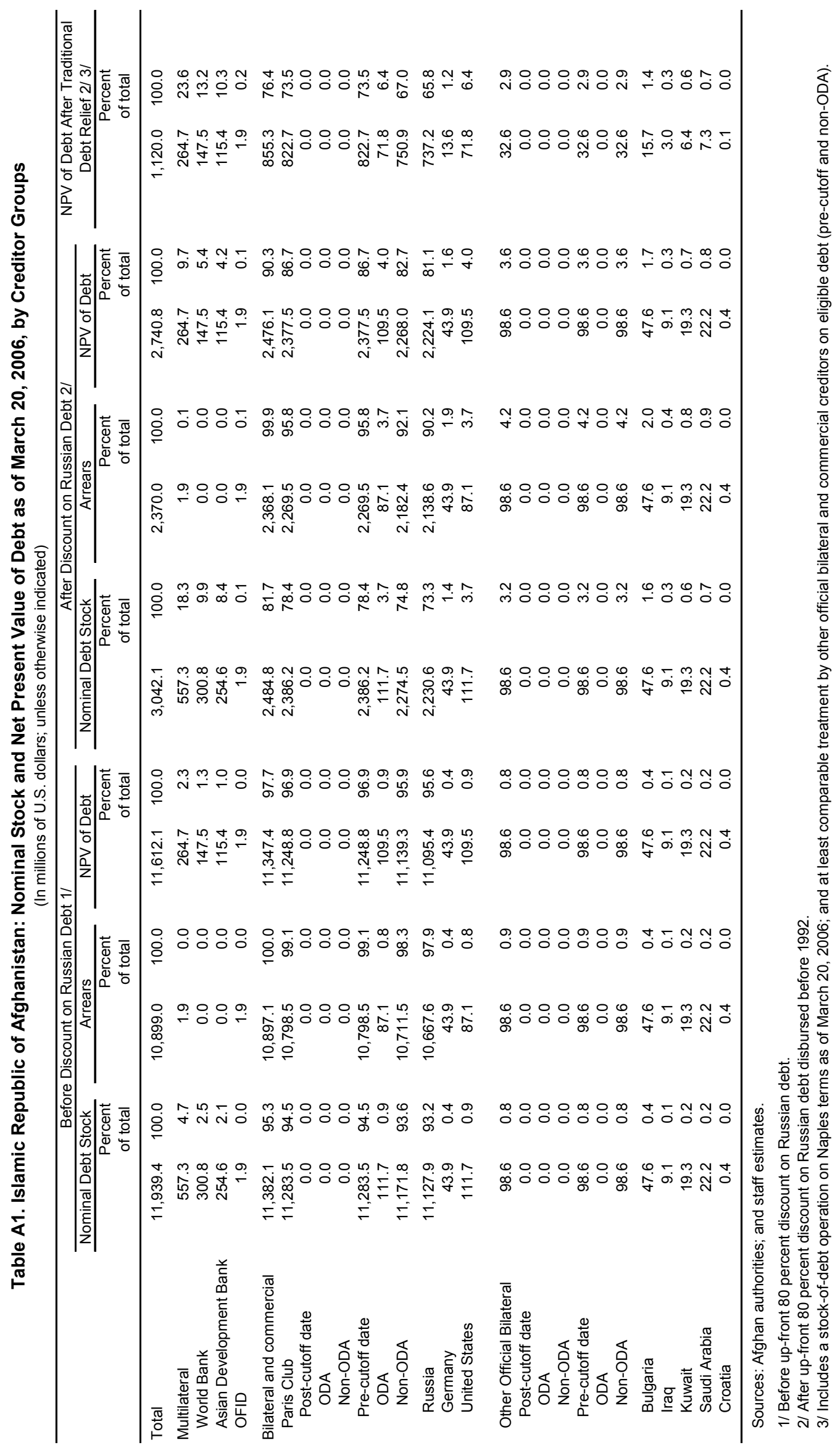


Table A2. Islamic Republic of Afghanistan: Discount Rates and Exchange Rates at end-March 2006

\begin{tabular}{lcc}
\hline Currency Name & $\begin{array}{c}\text { Discount Rate 1/ } \\
\text { (In percent per annum) }\end{array}$ & $\begin{array}{c}\text { Exchange Rate 2/ } \\
\text { (U.S. dollars per currency) }\end{array}$ \\
\hline Special drawing rights & 4.54 & 1.44 \\
Domestic currency: Afghani & 4.54 & 0.02 \\
Kuwait dinar & 5.32 & 3.42 \\
Russian ruble & 4.54 & 1.67 \\
U.A.E. dirham & 4.54 & 0.27 \\
United Kingdom pound sterling & 5.20 & 1.73 \\
United States dollar & 5.32 & 1.00 \\
Euro & 4.10 & 1.21 \\
Japanese yen & 2.11 & 0.01 \\
Korean won & 6.09 & 0.00 \\
Norwegian krone & 4.42 & 0.15 \\
Swedish krona & 4.08 & 0.13 \\
Swiss franc & 2.90 & 0.77 \\
Memorandum item: & & \\
Paris Club cutoff date & June 20,1999 & \\
\hline
\end{tabular}

Sources: Organization for Economic Cooperation and Development; and IMF, International Financial Statistics.

$1 /$ The discount rates used are the average commercial interest reference rates over the six-month period prior to the reference date (i.e., the end of the period for which actual debt and export data are available).

2/ The exchange rates are expressed as national currency per U.S. dollar at the end of the reference date. 
Table A3. Islamic Republic of Afghanistan: External Debt Service, 2006/07-2025/26 1/

(In millions of U.S. dollars; unless otherwise indicated)

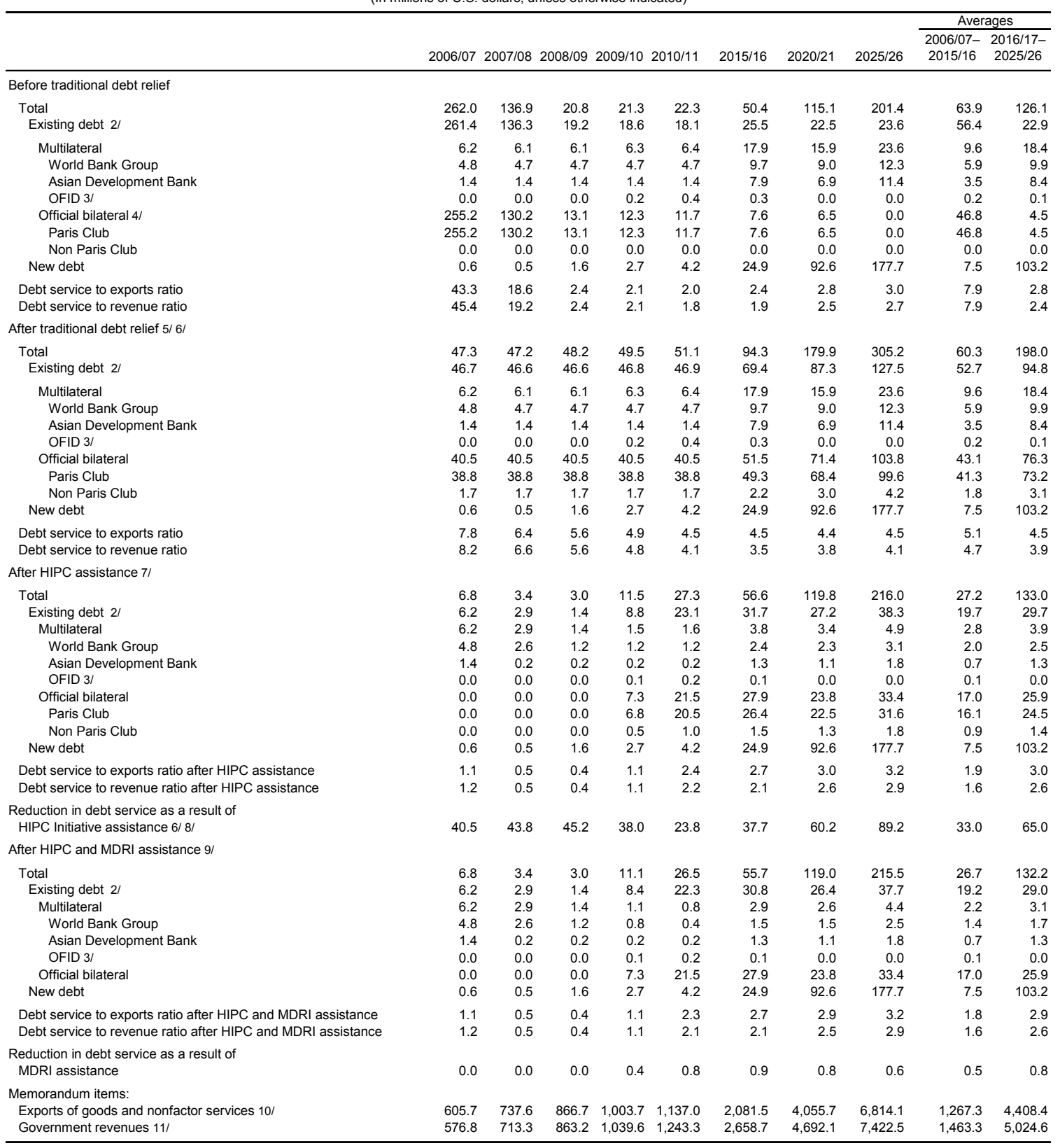

Sources: Afghan authorities; and staff estimates and projections.

1/ All debt indicators refer to public and publicly guaranteed debt and are defined after rescheduling, unless otherwise indicated. Fiscal year ends March 20.

$2 /$ Includes only scheduled debt service on current maturities and does not include projected penalty interest on arrears. For OFID, a rescheduling of arrears is assumed in order to obtain a debt service projection.

3/ Assumes a debt restructuring of current arrears translating into debt servicing after completion point.

4/ Does not include repayment of, or debt services on, amounts in arrears.

5/ Assumes an up-front 80 percent discount on Russian debt disbursed before 1992, and a hypothetical stock of debt operation on Naples terms and comparable treatment from other bilateral creditors.

6/ This does not take into account the Paris Club rescheduling of July 2006.

7/ Paris Club creditors are assumed to provide full delivery of HIPC assistance through a Cologne flow rescheduling on eligible debt during interim period and a stock of debt operation on Cologne terms on the remaining balance at the completion point (mid-2009). Non-Paris Club creditors are assumed to provide assistance on comparable terms. Multilateral creditors are also assumed to provide HIPC debt relief as of the completion point, except for the World Bank and the AsDB, for which the delivery would start after the decision point.

8/ The reduction is measured as the difference between the projected debt service after full use of traditional debt relief and debt service after the application of HIPC relief.
the decion point. $9 / \mathrm{MDRI}$ assistance applies only to the World Bank and starts at the beginning of the quarter following the completion point (October 2009). Assumes that MDRI has no impact on Afghanistan's new borrowing over the projection period.

10/ Based on official merchandise exports reported by Afghanistan's Central Statistics Office and staff estimates for exports of services; excluding transit goods.

$11 /$ Revenues are defined as central government revenues, excluding grants. 
Table A4. Islamic Republic of Afghanistan: Net Present Value of External Debt, 2005/06-2025/26 1/

\begin{tabular}{|c|c|c|c|c|c|c|c|c|c|c|c|}
\hline & \multirow[b]{2}{*}{ 2005/06 } & \multirow[b]{2}{*}{ 2006/07 } & \multirow[b]{2}{*}{$2007 / 08$} & & & & & & & Avera & ages \\
\hline & & & & 2008/09 & 2009/10 & 2010/11 & 2015/16 & $2020 / 21$ & $2025 / 26$ & $\begin{array}{c}2005 / 06- \\
2015 / 16\end{array}$ & $\begin{array}{c}2016 / 17- \\
2025 / 26\end{array}$ \\
\hline Before traditional debt-relief & & & & & & & & & & & \\
\hline NPV of total debt & $11,612.1$ & $11,454.8$ & $11,406.1$ & $11,472.2$ & $11,541.3$ & $11,639.3$ & $12,351.7$ & $13,198.4$ & $13,881.6$ & $11,753.9$ & $13,251.8$ \\
\hline NPV of outstanding debt & $11,612.1$ & $11,383.6$ & $11,269.7$ & $11,267.7$ & $11,266.3$ & $11,265.2$ & $11,238.6$ & $11,196.0$ & $11,150.6$ & $11,303.2$ & $11,192.3$ \\
\hline Official bilateral & $11,347.4$ & $11,112.9$ & $10,992.7$ & $10,984.1$ & $10,975.8$ & $10,967.7$ & $10,935.1$ & $10,906.3$ & $10,897.1$ & $11,010.6$ & $10,908.5$ \\
\hline Paris Club & $11,248.8$ & $11,014.3$ & $10,894.1$ & $10,885.5$ & $10,877.2$ & $10,869.1$ & $10,836.5$ & $10,807.7$ & $10,798.5$ & $10,912.0$ & $10,809.8$ \\
\hline Other official bilateral & 98.6 & 98.6 & 98.6 & 98.6 & 98.6 & 98.6 & 98.6 & 98.6 & 98.6 & 98.6 & 98.6 \\
\hline Multilateral & 264.7 & 270.7 & 277.0 & 283.6 & 290.5 & 297.5 & 303.4 & 289.6 & 253.5 & 292.6 & 283.9 \\
\hline World Bank & 147.5 & 149.6 & 151.9 & 154.3 & 156.8 & 159.4 & 162.2 & 151.5 & 132.4 & 158.1 & 149.1 \\
\hline Asian Development Bank & 115.4 & 119.1 & 123.0 & 127.1 & 131.5 & 136.2 & 140.5 & 138.1 & 121.1 & 132.9 & 134.7 \\
\hline OFID 2/ & 1.9 & 2.0 & 2.1 & 2.2 & 2.2 & 1.9 & 0.7 & 0.0 & 0.0 & 1.7 & 0.1 \\
\hline NPV of new borrowing & $\ldots$ & 71.2 & 136.5 & 204.5 & 275.1 & 374.1 & 1,113.1 & $2,002.4$ & $2,731.0$ & 495.8 & $2,059.5$ \\
\hline After traditional debt-relief $3 /$ & & & & & & & & & & & \\
\hline NPV of total debt & $1,120.0$ & $1,197.4$ & $1,269.1$ & $1,344.1$ & $1,421.7$ & $1,528.0$ & $2,247.0$ & $2,997.3$ & $3,384.2$ & $1,595.0$ & $2,996.6$ \\
\hline NPV of outstanding debt & $1,120.0$ & $1,126.2$ & $1,132.7$ & $1,139.6$ & $1,146.6$ & $1,153.9$ & $1,133.9$ & 994.9 & 653.2 & $1,144.3$ & 937.1 \\
\hline Official bilateral & 855.3 & 855.5 & 855.7 & 855.9 & 856.2 & 856.4 & 830.4 & 705.2 & 399.7 & 851.7 & 653.2 \\
\hline Paris Club & 822.7 & 822.9 & 823.1 & 823.4 & 823.6 & 823.9 & 799.2 & 679.4 & 386.6 & 819.4 & 629.5 \\
\hline Other official bilateral & 32.6 & 32.6 & 32.6 & 32.5 & 32.5 & 32.5 & 31.3 & 25.8 & 13.1 & 32.3 & 23.7 \\
\hline Multilateral & 264.7 & 270.7 & 277.0 & 283.6 & 290.5 & 297.5 & 303.4 & 289.6 & 253.5 & 292.6 & 283.9 \\
\hline World Bank & 147.5 & 149.6 & 151.9 & 154.3 & 156.8 & 159.4 & 162.2 & 151.5 & 132.4 & 158.1 & 149.1 \\
\hline Asian Development Bank & 115.4 & 119.1 & 123.0 & 127.1 & 131.5 & 136.2 & 140.5 & 138.1 & 121.1 & 132.9 & 134.7 \\
\hline OFID $2 /$ & 1.9 & 2.0 & 2.1 & 2.2 & 2.2 & 1.9 & 0.7 & 0.0 & 0.0 & 1.7 & 0.1 \\
\hline NPV of new borrowing & $\ldots$ & 71.2 & 136.5 & 204.5 & 275.1 & 374.1 & $1,113.1$ & $2,002.4$ & $2,731.0$ & 495.8 & $2,059.5$ \\
\hline Memorandum items: & & & & & & & & & & & \\
\hline NPV of debt-to-exports ratio (percer & & & & & & & & & & & \\
\hline Total debt & 306.2 & 237.2 & 205.8 & 182.5 & 163.5 & 152.4 & 120.9 & 82.9 & 54.8 & 173.3 & 82.3 \\
\hline Outstanding debt & 306.2 & 223.1 & 183.6 & 154.7 & 131.9 & 115.1 & 61.0 & 27.5 & 10.6 & 137.8 & 28.0 \\
\hline NPV of debt-to-revenue ratio (perce & & & & & & & & & & & \\
\hline Total debt & 269.3 & 207.6 & 177.9 & 155.7 & 136.8 & 122.9 & 84.5 & 63.9 & 45.6 & 141.3 & 62.8 \\
\hline Outstanding debt & 269.3 & 195.3 & 158.8 & 132.0 & 110.3 & 92.8 & 42.6 & 21.2 & 8.8 & 114.1 & 21.1 \\
\hline After conditional delivery of enhanced & assistance & & & & & & & & & & \\
\hline NPV of total debt & $2,740.8$ & $1,208.7$ & $1,284.9$ & $1,418.6$ & 826.1 & 928.5 & $1,642.5$ & $2,517.6$ & $3,200.2$ & $1,364.4$ & $2,565.1$ \\
\hline NPV of outstanding debt & $2,740.8$ & $1,137.4$ & $1,148.5$ & $1,214.1$ & 551.0 & 554.4 & 529.4 & 515.1 & 469.2 & 913.8 & 505.6 \\
\hline Official bilateral & $2,476.1$ & 866.7 & 877.3 & 931.8 & 401.8 & 399.9 & 351.0 & 311.1 & 236.1 & 710.1 & 298.1 \\
\hline Paris Club 6/ & $2,377.5$ & 834.1 & 843.4 & 895.6 & 383.2 & 381.2 & 334.7 & 297.3 & 226.8 & 680.5 & 285.1 \\
\hline Other official bilateral & 98.6 & 32.6 & 33.9 & 36.2 & 18.6 & 18.7 & 16.2 & 13.8 & 9.3 & 29.6 & 13.0 \\
\hline Multilateral & 264.7 & 270.7 & 271.2 & 282.3 & 149.2 & 154.5 & 178.4 & 204.1 & 233.1 & 203.7 & 207.5 \\
\hline World Bank & 147.5 & 149.6 & 147.2 & 152.9 & 82.9 & 85.5 & 97.5 & 108.9 & 121.7 & 112.0 & 110.5 \\
\hline Asian Development Bank & 115.4 & 119.1 & 121.8 & 127.1 & 65.2 & 68.0 & 80.5 & 95.1 & 111.4 & 90.5 & 97.0 \\
\hline OFID $2 /$ & 1.9 & 2.0 & 2.1 & 2.2 & 1.1 & 0.9 & 0.4 & 0.0 & 0.0 & 1.2 & 0.0 \\
\hline NPV of new borrowing & $\ldots$ & 71.2 & 136.5 & 204.5 & 275.1 & 374.1 & $1,113.1$ & $2,002.4$ & $2,731.0$ & 495.8 & $2,059.5$ \\
\hline After unconditional delivery of enhanc & $\mathrm{C}$ assistan & cee $7 /$ & & & & & & & & & \\
\hline NPV of total debt & 548.6 & 557.7 & 643.3 & 734.1 & 826.1 & 928.5 & $1,642.5$ & $2,517.6$ & $3,200.2$ & 985.4 & $2,565.1$ \\
\hline NPV of outstanding debt & 548.6 & 486.4 & 506.8 & 529.6 & 551.0 & 554.4 & 529.4 & 515.1 & 469.2 & 534.7 & 505.6 \\
\hline Official bilateral & 418.9 & 350.7 & 367.7 & 385.6 & 401.8 & 399.9 & 351.0 & 311.1 & 236.1 & 380.2 & 298.1 \\
\hline Paris Club & 403.0 & 334.5 & 350.7 & 367.6 & 383.2 & 381.2 & 334.7 & 297.3 & 226.8 & 362.8 & 285.1 \\
\hline Other official bilateral & 16.0 & 16.2 & 17.1 & 18.0 & 18.6 & 18.7 & 16.2 & 13.8 & 9.3 & 17.4 & 13.0 \\
\hline Multilateral & 129.7 & 135.7 & 139.1 & 144.1 & 149.2 & 154.5 & 178.4 & 204.1 & 233.1 & 154.6 & 207.5 \\
\hline World Bank & 78.2 & 77.1 & 78.0 & 80.4 & 82.9 & 85.5 & 97.5 & 108.9 & 121.7 & 86.2 & 110.5 \\
\hline Asian Development Bank & 56.5 & 57.6 & 60.0 & 62.6 & 65.2 & 68.0 & 80.5 & 95.1 & 111.4 & 68.1 & 97.0 \\
\hline OFID $2 /$ & 0.9 & 1.0 & 1.0 & 1.1 & 1.1 & 0.9 & 0.4 & 0.0 & 0.0 & 0.8 & 0.0 \\
\hline NPV of new borrowing & $\ldots$ & 71.2 & 136.5 & 204.5 & 275.1 & 374.1 & 1,113.1 & $2,002.4$ & $2,731.0$ & 495.8 & $2,059.5$ \\
\hline Memorandum items: & & & & & & & & & & & \\
\hline NPV of debt-to-exports rati & & & & & & & & & & & \\
\hline Total debt & 749.4 & 239.5 & 208.3 & 192.6 & 95.0 & 92.6 & 88.4 & 69.6 & 51.8 & 183.9 & 68.8 \\
\hline Total debt, assuming full delivery & 150.0 & 110.5 & 104.3 & 99.7 & 95.0 & 92.6 & 88.4 & 69.6 & 51.8 & 99.8 & 68.8 \\
\hline Outstanding debt & 749.4 & 225.4 & 186.2 & 164.8 & 63.4 & 55.3 & 28.5 & 14.2 & 7.6 & 148.4 & 14.5 \\
\hline NPV of debt-to-revenue ratio (perce & & & & & & & & & & & \\
\hline Total debt & 659.0 & 209.6 & 180.1 & 164.3 & 79.5 & 74.7 & 61.8 & 53.7 & 43.1 & 154.0 & 52.7 \\
\hline Total debt, assuming full delive & 131.9 & 96.7 & 90.2 & 85.0 & 79.5 & 74.7 & 61.8 & 53.7 & 43.1 & 80.4 & 52.7 \\
\hline Outstanding debt & 659.0 & 197.2 & 161.0 & 140.6 & 53.0 & 44.6 & 19.9 & 11.0 & 6.3 & 126.8 & 11.0 \\
\hline After conditional delivery of enhanced & and MDRI & assistance & $5 / 8 /$ & & & & & & & & \\
\hline NPV of total debt & $2,740.8$ & $1,208.7$ & $1,284.9$ & $1,418.6$ & 809.2 & 911.5 & $1,625.8$ & $2,501.3$ & $3,183.7$ & $1,353.7$ & $2,548.7$ \\
\hline NPV of outstanding debt & $2,740.8$ & $1,137.4$ & $1,148.5$ & $1,214.1$ & 534.1 & 537.4 & 512.7 & 498.9 & 452 & 903.0 & 489.2 \\
\hline Official bilateral $5 /$ & $2,476.1$ & 866.7 & 877.3 & 931.8 & 401.8 & 399.9 & 351.0 & 311.1 & 236.1 & 710.1 & 298.1 \\
\hline Paris Club & $2,377.5$ & 834.1 & 843.4 & 895.6 & 383.2 & 381.2 & 334.7 & 297.3 & 226.8 & 680.5 & 285.1 \\
\hline Other official bilateral & 98.6 & 32.6 & 33.9 & 36.2 & 18.6 & 18.7 & 16.2 & 13.8 & 9.3 & 29.6 & 13.0 \\
\hline Multilateral & 264.7 & 270.7 & 271.2 & 282.3 & 132.3 & 137.6 & 161.7 & 187.8 & 216.6 & 192.9 & 191.1 \\
\hline World Bank & 147.5 & 149.6 & 147.2 & 152.9 & 66.0 & 68.6 & 80.8 & 92.7 & 105.1 & 101.2 & 94.1 \\
\hline Asian Development Bank & 115.4 & 119.1 & 121.8 & 127.1 & 65.2 & 68.0 & 80.5 & 95.1 & 111.4 & 90.5 & 97.0 \\
\hline OFID 21 & 1.9 & 2.0 & 2.1 & 2.2 & 1.1 & 0.9 & 0.4 & 0.0 & 0.0 & 1.2 & 0.0 \\
\hline NPV of new borrowing & $\ldots$ & 71.2 & 136.5 & 204.5 & 275.1 & 374.1 & $1,113.1$ & $2,002.4$ & $2,731.0$ & 495.8 & $2,059.5$ \\
\hline Memorandum items: & & & & & & & & & & & \\
\hline NPV of debt-to-exports ratio (percer & & & & & & & & & & & \\
\hline Total debt & 749.4 & 239.5 & 208.3 & 192.6 & 93.1 & 90.9 & 87.5 & 69.2 & 51.6 & 183.1 & 68.4 \\
\hline Total debt, assuming full delivery & 150.0 & 110.5 & 104.3 & 99.7 & 93.1 & 90.9 & 87.5 & 69.2 & 51.6 & 99.0 & 68.4 \\
\hline NPV of debt-to-revenue ratio (perce & & & & & & & & & & & \\
\hline Total debt & 659.0 & 209.6 & 180.1 & 164.3 & 77.8 & 73.3 & 61.1 & 53.3 & 42.9 & 153.3 & 52.4 \\
\hline Total debt, assuming full delivery & 131.9 & 96.7 & 90.2 & 164.3 & 77.8 & 73.3 & 61.1 & 53.3 & 42.9 & 87.0 & 52.4 \\
\hline
\end{tabular}

Sources: Afghan authorities and staff estimates and projections.

$1 /$ Fiscal year ends March 20

2/ Assumes a debt restructuring of current arrears translating into debt servicing after completion point.

3/ The traditional debt relief is a hypothetical scenario of stock-of-debt rescheduling under Naples terms at the end of the fiscal year (March 20, 2006). It also assumes an 80 percent of up-front discount on Russian debt disbursed before 1992.

$4 /$ In terms of simple historical three-year average of exports of goods and services; excluding transit goods.

5/ NPV of external debt is contingent upon reaching the different "debt relief" milestones. Starting in 2005-06, the conditional scenario assumes the up-front discount on Russian debt disbursed before 1992. For 2006-07, it assumes Naples flow rescheduling (April 1, 2006 to March 30, 2009). For 2007-08 and 2008-09, after Afghanistan is assumed to have reached decision point, the conditional scenario assumes flow rescheduling under Cologne terms and interim debt relief by multilateral creditors (July 2007-June 2009). For 2009-10 onward, when Afghanistan is assumed to have reached completion point (July 2009), the conditional scenario assumes stock-of-debt cancellation under Cologne terms and irrevocable debt relief by multilateral creditors. Non-Paris Club creditors are assumed to provide comparable

6/ For 2005/06, after up-front 80 percent discount on Russian debt disbursed before 1992, and prior to the conditional delivery of enhanced HIPC assistance from July 2007 to June 2009.

$7 /$ The unconditional scenario assumes full delivery of estimated enhanced HIPC Initiative debt relief as of March 20, 2006. Accordingly, the NPV of debt-to-exports atio is reduced to 150 percent for 2005-06.

8/ MDRI assistance applies only to the World Bank and starts at the beginning of the quarter following the completion point (October 2009). Assumes that MDRI has no impact on Afghanistan's new borrowing over the projection period. Does not include commitments by Paris Club creditors to cancel 100 percent of Afghanistan's debt. 
Table A5. Islamic Republic of Afghanistan: External Debt Indicators, 2005/06-2025/26 1/

(In percent; unless otherwise indicated)

\begin{tabular}{|c|c|c|c|c|c|c|c|c|c|c|c|}
\hline & \multirow[b]{2}{*}{ 2005/06 } & \multirow[b]{2}{*}{$2006 / 07$} & \multirow[b]{2}{*}{$2007 / 08$} & \multirow[b]{2}{*}{$2008 / 09$} & \multirow[b]{2}{*}{$2009 / 10$} & \multirow[b]{2}{*}{ 2010/11 } & \multirow[b]{2}{*}{$2015 / 16$} & \multirow[b]{2}{*}{$2020 / 21$} & \multirow[b]{2}{*}{$2025 / 26$} & \multicolumn{2}{|c|}{ Averages } \\
\hline & & & & & & & & & & $\begin{array}{c}2005 / 06- \\
2015 / 16\end{array}$ & $\begin{array}{c}2016 / 17- \\
2025 / 26\end{array}$ \\
\hline \multicolumn{12}{|l|}{ Before traditional debt relief } \\
\hline NPV of debt-to-GDP ratio & 158.9 & 138.8 & 117.3 & 104.0 & 93.5 & 84.8 & 53.7 & 35.8 & 23.7 & 92.7 & 35.3 \\
\hline NPV of debt-to-exports ratio $2 / 3$ / & 3174.9 & 2269.6 & 1849.2 & 1557.3 & 1327.7 & 1161.1 & 664.5 & 365.0 & 224.8 & $1,409.9$ & 372.9 \\
\hline NPV of debt-to-revenue ratio 4/ & 2792.2 & 1986.1 & 1599.1 & 1329.0 & 1110.2 & 936.2 & 464.6 & 281.3 & 187.0 & $1,165.9$ & 283.2 \\
\hline Debt service-to-exports ratio 3 / & $\ldots$ & 43.3 & 18.6 & 2.4 & 2.1 & 2.0 & 2.4 & 2.8 & 3.0 & 7.9 & 2.8 \\
\hline Debt service-to-revenue ratio 4/ & $\cdots$ & 45.4 & 19.2 & 2.4 & 2.1 & 1.8 & 1.9 & 2.5 & 2.7 & 7.9 & 2.4 \\
\hline \multicolumn{12}{|l|}{ After traditional debt relief } \\
\hline NPV of debt-to-GDP ratio & 15.3 & 14.5 & 13.1 & 12.2 & 11.5 & 11.1 & 9.8 & 8.1 & 5.8 & 11.7 & 7.8 \\
\hline NPV of debt-to-exports ratio $2 / 3$ / & 306.2 & 237.2 & 205.8 & 182.5 & 163.5 & 152.4 & 120.9 & 82.9 & 54.8 & 173.3 & 82.3 \\
\hline NPV of debt-to-revenue ratio 4/ & 269.3 & 207.6 & 177.9 & 155.7 & 136.8 & 122.9 & 84.5 & 63.9 & 45.6 & 141.3 & 62.8 \\
\hline Debt service-to-exports ratio $3 /$ & $\ldots$ & 7.8 & 6.4 & 5.6 & 4.9 & 4.5 & 4.5 & 4.4 & 4.5 & 5.1 & 4.5 \\
\hline Debt service-to-revenue ratio 4 / & $\ldots$ & 8.2 & 6.6 & 5.6 & 4.8 & 4.1 & 3.5 & 3.8 & 4.1 & 4.7 & 3.9 \\
\hline \multicolumn{12}{|l|}{ After conditional delivery of enhanced HIPC assistance } \\
\hline NPV of debt-to-GDP ratio & 37.5 & 14.6 & 13.2 & 12.9 & 6.7 & 6.8 & 7.1 & 6.8 & 5.5 & 11.5 & 6.6 \\
\hline NPV of debt-to-exports ratio $2 / 3 /$ & 749.4 & 239.5 & 208.3 & 192.6 & 95.0 & 92.6 & 88.4 & 69.6 & 51.8 & 183.9 & 68.8 \\
\hline NPV of debt-to-exports ratio (existing debt only) $2 / 3 /$ & 749.4 & 225.4 & 186.2 & 164.8 & 63.4 & 55.3 & 28.5 & 14.2 & 7.6 & 148.4 & 14.5 \\
\hline NPV of debt-to-revenue ratio $4 /$ & 659.0 & 209.6 & 180.1 & 164.3 & 79.5 & 74.7 & 61.8 & 53.7 & 43.1 & 154.0 & 52.7 \\
\hline Debt service-to-exports ratio $3 /$ & $\ldots$ & 1.1 & 0.5 & 0.4 & 1.1 & 2.4 & 2.7 & 3.0 & 3.2 & 1.9 & 3.0 \\
\hline Debt service-to-revenue ratio 4 / & $\cdots$ & 1.2 & 0.5 & 0.4 & 1.1 & 2.2 & 2.1 & 2.6 & 2.9 & 1.6 & 2.6 \\
\hline \multicolumn{12}{|l|}{ After unconditional delivery of enhanced HIPC assistance } \\
\hline NPV of debt-to-GDP ratio & 7.5 & 6.8 & 6.6 & 6.7 & 6.7 & 6.8 & 7.1 & 6.8 & 5.5 & 6.9 & 6.6 \\
\hline NPV of debt-to-exports ratio $2 / 3 /$ & 150.0 & 110.5 & 104.3 & 99.7 & 95.0 & 92.6 & 88.4 & 69.6 & 51.8 & 99.8 & 68.8 \\
\hline NPV of debt-to-exports ratio (existing debt only) $2 / 3 /$ & 150.0 & 96.4 & 82.2 & 71.9 & 63.4 & 55.3 & 28.5 & 14.2 & 7.6 & 64.3 & 14.5 \\
\hline NPV of debt-to-revenue ratio $4 /$ & 131.9 & 96.7 & 90.2 & 85.0 & 79.5 & 74.7 & 61.8 & 53.7 & 43.1 & 80.4 & 52.7 \\
\hline Debt service-to-exports ratio $3 /$ & $\ldots$ & 1.1 & 0.5 & 0.4 & 1.1 & 2.4 & 2.7 & 3.0 & 3.2 & 1.9 & 3.0 \\
\hline Debt service-to-revenue ratio 4 / & $\ldots$ & 1.2 & 0.5 & 0.4 & 1.1 & 2.2 & 2.1 & 2.6 & 2.9 & 1.6 & 2.6 \\
\hline \multicolumn{12}{|c|}{ After conditional delivery of enhanced HIPC and MDRI assistance 5/ } \\
\hline NPV of debt-to-GDP ratio & 37.5 & 14.6 & 13.2 & 12.9 & 6.6 & 6.6 & 7.1 & 6.8 & 5.4 & 11.4 & 6.5 \\
\hline NPV of debt-to-exports ratio $2 / 3 /$ & 749.4 & 239.5 & 208.3 & 192.6 & 93.1 & 90.9 & 87.5 & 69.2 & 51.6 & 183.1 & 68.4 \\
\hline NPV of debt-to-exports ratio (existing debt only) $2 / 3 /$ & 749.4 & 225.4 & 186.2 & 164.8 & 61.4 & 53.6 & 27.6 & 13.8 & 7.3 & 147.6 & 14.0 \\
\hline NPV of debt-to-revenue ratio $3 /$ & 659.0 & 209.6 & 180.1 & 164.3 & 77.8 & 73.3 & 61.1 & 53.3 & 42.9 & 153.3 & 52.4 \\
\hline Debt service-to-exports ratio 2/ 4/ & $\ldots$ & 1.1 & 0.5 & 0.4 & 1.1 & 2.3 & 2.7 & 2.9 & 3.2 & 1.8 & 2.9 \\
\hline Debt service-to-revenue ratio 4/ & $\ldots$ & 1.2 & 0.5 & 0.4 & 1.1 & 2.1 & 2.1 & 2.5 & 2.9 & 1.6 & 2.6 \\
\hline
\end{tabular}

Sources: Afghan authorities; and staff estimates and projections.

1/ All debt indicators refer to public and publicly guaranteed debt as of March 20, 2006. Fiscal year ends on March 20.

2/ Based on a three-year average of exports of goods and services on the previous years; excluding transit goods (e.g., export average over 2004-06 for NPV of debt-to-exports ratio in 2006).

3/ Based on official merchandise exports reported by Afghanistan's Central Statistics Office and staff estimates for exports of services; excluding transit goods.

4/ Revenue is defined as central government revenue, excluding grants.

5/ MDRI assistance applies only to the World Bank and starts at the beginning of the quarter following the completion point (October 2009). Assumes that MDRI has no impact on

Afghanistan's new borrowing over the projection period. 
Table A6. Islamic Republic of Afghanistan: External Debt Indicators and Sensitivity Analysis, 2005/06-2025/26 1/ (In percent; unless otherwise indicated)

\begin{tabular}{|c|c|c|c|c|c|c|c|c|c|c|c|}
\hline & \multirow[b]{2}{*}{$2005 / 06$} & \multirow[b]{2}{*}{ 2006/07 } & \multirow[b]{2}{*}{$2007 / 08$} & \multirow[b]{2}{*}{ 2008/09 } & \multirow[b]{2}{*}{$2009 / 10$} & \multirow[b]{2}{*}{ 2010/11 } & \multirow[b]{2}{*}{ 2015/16 } & \multirow[b]{2}{*}{$2020 / 21$} & \multirow[b]{2}{*}{$2025 / 26$} & \multicolumn{2}{|c|}{ Averages } \\
\hline & & & & & & & & & & $\begin{array}{l}2005 / 06- \\
2015 / 16\end{array}$ & $\begin{array}{l}2016 / 17- \\
2025 / 26\end{array}$ \\
\hline \multicolumn{12}{|l|}{ Baseline scenario } \\
\hline NPV of debt-to-GDP ratio & 7.5 & 6.8 & 6.6 & 6.7 & 6.7 & 6.8 & 7.1 & 6.8 & 5.5 & 6.9 & 6.6 \\
\hline NPV of debt-to-exports ratio $2 / 3 /$ & 150.0 & 110.5 & 104.3 & 99.7 & 95.0 & 92.6 & 88.4 & 69.6 & 51.8 & 99.8 & 68.8 \\
\hline NPV of debt-to-revenue ratio 4/ & 131.9 & 96.7 & 90.2 & 85.0 & 79.5 & 74.7 & 61.8 & 53.7 & 43.1 & 80.4 & 52.7 \\
\hline Debt service-to-exports ratio 3/ & $\ldots$ & 1.1 & 0.5 & 0.4 & 1.1 & 2.4 & 2.7 & 3.0 & 3.2 & 1.9 & 3.0 \\
\hline Debt service-to-revenue ratio $4 /$ & $\ldots$ & 1.2 & 0.5 & 0.4 & 1.1 & 2.2 & 2.1 & 2.6 & 2.9 & 1.6 & 2.6 \\
\hline \multicolumn{12}{|c|}{ Sensitivity analysis } \\
\hline \multicolumn{12}{|c|}{ Less concessional new borrowing scenario 5 / } \\
\hline NPV of debt-to-GDP ratio & 7.5 & 7.2 & 7.4 & 7.7 & 7.9 & 8.2 & 9.6 & 9.6 & 8.1 & 8.3 & 9.3 \\
\hline NPV of debt-to-exports ratio $2 / 3 /$ & 150.0 & 118.4 & 116.4 & 114.7 & 112.1 & 112.5 & 118.6 & 97.8 & 76.5 & 118.3 & 96.8 \\
\hline NPV of debt-to-revenue ratio 4/ & 132.7 & 104.0 & 100.7 & 97.9 & 93.7 & 90.7 & 82.9 & 75.4 & 63.6 & 94.8 & 74.3 \\
\hline Debt service-to-exports ratio $3 /$ & $\ldots$ & 1.1 & 0.7 & 0.9 & 1.9 & 3.4 & 4.7 & 5.1 & 5.1 & 2.9 & 5.0 \\
\hline Debt service-to-revenue ratio 4 / & $\ldots$ & 1.2 & 0.7 & 0.9 & 1.8 & 3.1 & 3.7 & 4.4 & 4.7 & 2.5 & 4.4 \\
\hline \multicolumn{12}{|l|}{ Lower transfers/grants 6/ } \\
\hline NPV of debt-to-GDP ratio & 7.5 & 6.8 & 6.6 & 6.7 & 7.0 & 7.4 & 9.7 & 11.2 & 11.4 & 7.8 & 11.1 \\
\hline NPV of debt-to-exports ratio $2 / 3 /$ & 150.0 & 110.5 & 104.3 & 99.7 & 100.0 & 101.3 & 119.8 & 114.2 & 108.3 & 111.8 & 114.8 \\
\hline NPV of debt-to-revenue ratio $4 /$ & 132.7 & 97.0 & 90.2 & 85.1 & 83.7 & 81.6 & 83.7 & 88.0 & 90.1 & 89.3 & 88.6 \\
\hline Debt service-to-exports ratio 3/ & $\ldots$ & 1.1 & 0.5 & 0.4 & 1.2 & 2.5 & 3.6 & 4.9 & 5.9 & 2.2 & 4.9 \\
\hline Debt service-to-revenue ratio 4/ & $\ldots$ & 1.2 & 0.5 & 0.4 & 1.1 & 2.3 & 2.8 & 4.2 & 5.4 & 1.9 & 4.3 \\
\hline \multicolumn{12}{|l|}{ Lower export prices $7 /$} \\
\hline NPV of debt-to-GDP ratio & 7.5 & 6.8 & 6.6 & 6.7 & 6.9 & 7.0 & 8.3 & 10.3 & 12.4 & 7.3 & 10.6 \\
\hline NPV of debt-to-exports ratio $2 / 3 /$ & 150.0 & 110.5 & 105.0 & 101.7 & 98.8 & 98.1 & 108.5 & 114.1 & 131.3 & 107.2 & 118.5 \\
\hline NPV of debt-to-revenue ratio 4/ & 132.7 & 97.0 & 90.6 & 86.1 & 81.4 & 77.4 & 71.6 & 80.2 & 96.1 & 84.3 & 83.3 \\
\hline Debt service-to-exports ratio 3 / & $\ldots$ & 1.1 & 0.5 & 0.4 & 1.2 & 2.5 & 3.3 & 4.5 & 6.4 & 2.1 & 4.7 \\
\hline Debt service-to-revenue ratio 4/ & $\cdots$ & 1.2 & 0.5 & 0.4 & 1.1 & 2.2 & 2.4 & 3.5 & 5.1 & 1.7 & 3.7 \\
\hline \multicolumn{12}{|l|}{ Lower GDP growth 8/ } \\
\hline NPV of debt-to-GDP ratio & 7.5 & 6.8 & 6.7 & 6.9 & 7.2 & 7.4 & 9.5 & 13.3 & 16.9 & 7.7 & 13.6 \\
\hline NPV of debt-to-exports ratio $2 / 3 /$ & 150.0 & 110.5 & 106.0 & 104.5 & 104.2 & 105.3 & 127.6 & 168.9 & 213.8 & 115.0 & 174.3 \\
\hline NPV of debt-to-revenue ratio 4/ & 132.7 & 97.0 & 91.7 & 88.5 & 85.2 & 81.9 & 82.1 & 103.8 & 133.4 & 88.8 & 108.4 \\
\hline Debt service-to-exports ratio 3 / & $\ldots$ & 1.1 & 0.5 & 0.4 & 1.3 & 2.7 & 3.9 & 6.5 & 10.2 & 2.3 & 7.0 \\
\hline Debt service-to-revenue ratio 4/ & $\ldots$ & 1.2 & 0.5 & 0.4 & 1.2 & 2.4 & 2.7 & 4.3 & 6.9 & 1.9 & 4.7 \\
\hline
\end{tabular}

Sources: Afghan authorities; and staff estimates and projections.

1/ All debt indicators refer to public and publicly guaranteed debt and are defined after HIPC assistance assumed delivered unconditionally at end-July 2007. Fiscal year ends on March 20

2/ Based on a three-year average of exports on the previous year (e.g., export average over 2004-06 for NPV of debt-to-exports ratio in 2006).

3/ Based on official merchandise exports reported by Afghanistan's Central Statistics Office and staff estimates for exports of services, excluding transit goods. 4/ Revenue is defined as central government revenue, excluding grants.

$5 /$ Assumes that the interest rate on all debt is 2 percentage point higher than in the baseline from 2007/08 onwards, implying a 20 percentage point reduction in grant element.

6/ Budgetary grants (i.e., operating and development budget grants, but not "external budget" grants) are 1 percentage point of GDP lower each year, starting in 2009/10 (or after the estimated time for the completion point). Additional financing needs are met with higher debt financing.

7/ Assumes export prices are 15 percent lower than in the baseline from 2007/08 onwards.

8/ Assumes 1.5 percentage points lower GDP growth, starting in 2007/08. 
Table A7. HIPC Initiative: Status of Country Cases Considered Under the Initiative, March 19, 2007

\begin{tabular}{|c|c|c|c|c|c|c|c|c|c|c|c|}
\hline \multirow[b]{2}{*}{ Country } & \multirow{2}{*}{$\begin{array}{l}\text { Decision } \\
\text { Point }\end{array}$} & \multirow{2}{*}{$\begin{array}{c}\text { Completion } \\
\text { Point }\end{array}$} & \multicolumn{2}{|c|}{$\begin{array}{c}\text { Target } \\
\text { NPV of Debt-to- } \\
\end{array}$} & \multicolumn{5}{|c|}{$\begin{array}{l}\text { Assistance Levels 1/ } \\
\text { (In millions of U.S. dollars, present value) }\end{array}$} & \multirow{2}{*}{$\begin{array}{l}\text { Percentage } \\
\text { Reduction } \\
\text { in NPV of } \\
\text { Debt 2/ }\end{array}$} & \multirow{2}{*}{$\begin{array}{c}\text { Estimated Tota } \\
\text { Nominal Debt } \\
\text { Service Relief } \\
\text { (In millions of } \\
\text { U.S. dollars) }\end{array}$} \\
\hline & & & $\frac{\text { Exports }}{\text { (in } \mathrm{p}}$ & $\begin{array}{c}\text { Gov. } \\
\text { revenue } \\
\text { rcent) }\end{array}$ & Total & $\begin{array}{r}\text { Bilateral and } \\
\text { commercial }\end{array}$ & $\begin{array}{l}\text { Multi- } \\
\text { lateral }\end{array}$ & IMF & $\begin{array}{r}\text { World } \\
\text { Bank } \\
\end{array}$ & & \\
\hline \multicolumn{12}{|c|}{ Completion point reached under enhanced framework (22) } \\
\hline Benin & Jul. 00 & Mar. 03 & 150 & & 265 & 77 & 189 & 24 & 84 & 31 & 460 \\
\hline Bolivia & & & & & 1,302 & 425 & 876 & 84 & 194 & & 2,060 \\
\hline Original framework & Sep. 97 & Sep. 98 & 225 & & 448 & 157 & 291 & 29 & 54 & 14 & 760 \\
\hline Enhanced framework & Feb. 00 & Jun. 01 & 150 & & 854 & 268 & 585 & 55 & 140 & 30 & 1,300 \\
\hline Burkina Faso & & & & & 553 & 83 & 469 & 57 & 231 & & 930 \\
\hline Original framework & Sep. 97 & Jul. 00 & 205 & & 229 & 32 & 196 & 22 & 91 & 27 & 400 \\
\hline Enhanced framework & Jul. 00 & Apr. 02 & 150 & & 195 & 35 & 161 & 22 & 79 & 30 & 300 \\
\hline Topping-up & (1). & Apr. 02 & 150 & & 129 & 16 & 112 & 14 & 61 & 24 & 230 \\
\hline Cameroon & Oct. 00 & Apr. 06 & 150 & & 1,267 & 879 & 322 & 37 & 176 & 27 & 4,917 \\
\hline Ethiopia & & & & & 1,982 & 637 & 1,315 & 60 & 832 & & 3,275 \\
\hline Enhanced framework & Nov. 01 & Apr. 04 & 150 & & 1,275 & 482 & 763 & 34 & 463 & 47 & 1,941 \\
\hline Topping-up & $\ldots$ & Apr. 04 & 150 & & 707 & 155 & 552 & 26 & 369 & 31 & 1,334 \\
\hline Ghana & Feb. 02 & Jul. 04 & 144 & 250 & 2,186 & 1,084 & 1,102 & 112 & 781 & 56 & 3,500 \\
\hline Guyana & & & & & 591 & 223 & 367 & 75 & 68 & & 1,354 \\
\hline Original framework & Dec. 97 & May 99 & 107 & 280 & 256 & 91 & 165 & 35 & 27 & 24 & 634 \\
\hline Enhanced framework & Nov. 00 & Dec. 03 & 150 & 250 & 335 & 132 & 202 & 40 & 41 & 40 & 719 \\
\hline Honduras & Jul. 00 & Mar. 05 & 110 & 250 & 556 & 215 & 340 & 30 & 98 & 18 & 1,000 \\
\hline Madagascar & Dec. 00 & Oct. 04 & 150 & & 836 & 474 & 362 & 19 & 252 & 40 & 1,900 \\
\hline Malawi & & & & & 1,057 & 171 & 886 & 45 & 622 & & 1,628 \\
\hline Enhanced framework & Dec. 00 & Aug. 06 & 150 & & 646 & 164 & 482 & 30 & 333 & 44 & 1,025 \\
\hline Topping-up & $\ldots$ & Aug. 06 & 150 & & 411 & 7 & 404 & 15 & 289 & 35 & 603 \\
\hline Mali & & & & & 539 & 169 & 370 & 59 & 185 & & 895 \\
\hline Original framework & Sep. 98 & Sep. 00 & 200 & & 121 & 37 & 84 & 14 & 43 & 9 & 220 \\
\hline Enhanced framework & Sep. 00 & Mar. 03 & 150 & & 417 & 132 & 285 & 45 & 143 & 29 & 675 \\
\hline Mauritania & Feb. 00 & Jun. 02 & 137 & 250 & 622 & 261 & 361 & 47 & 100 & 50 & 1,100 \\
\hline Mozambique & & & & & 2,023 & 1,270 & 753 & 143 & 443 & & 4,300 \\
\hline Original framework & Apr. 98 & Jun. 99 & 200 & & 1,717 & 1,076 & 641 & 125 & 381 & 63 & 3,700 \\
\hline Enhanced framework & Apr. 00 & Sep. 01 & 150 & & 306 & 194 & 112 & 18 & 62 & 27 & 600 \\
\hline Nicaragua & Dec. 00 & Jan. 04 & 150 & & 3,308 & 2,175 & 1,134 & 82 & 191 & 73 & 4,500 \\
\hline Niger & & & & & 663 & 235 & 428 & 42 & 240 & & 1,190 \\
\hline Enhanced framework & Dec. 00 & Apr. 04 & 150 & & 521 & 211 & 309 & 28 & 170 & 53 & 944 \\
\hline Topping-up & $\ldots$ & Apr. 04 & 150 & & 143 & 23 & 119 & 14 & 70 & 25 & 246 \\
\hline Rwanda & & & & & 696 & 65 & 631 & 63 & 383 & & 1,316 \\
\hline Enhanced framework & Dec. 00 & Apr. 05 & 150 & & 452 & 56 & 397 & 44 & 228 & 71 & 839 \\
\hline Topping-up & $\ldots$ & Apr. 05 & 150 & & 243 & 9 & 235 & 20 & 154 & 53 & 477 \\
\hline São Tomé and Príncipe & & & & & 124 & 31 & 93 & - & 47 & 128 & 263 \\
\hline Enhanced framework & Dec. 00 & Mar. 07 & 150 & & 99 & 29 & 70 & - & 24 & 83 & 215 \\
\hline Topping-up & $\ldots$ & Mar. 07 & 150 & & 25 & 2 & 23 & - & 23 & 45 & 49 \\
\hline Senegal & Jun. 00 & Apr. 04 & 133 & 250 & 488 & 212 & 276 & 45 & 124 & 19 & 850 \\
\hline Sierra Leone & Mar. 02 & Dec. 06 & 150 & & 675 & 335 & 340 & 125 & 123 & 81 & 994 \\
\hline Tanzania & Apr. 00 & Nov. 01 & 150 & & 2,026 & 1,006 & 1,020 & 120 & 695 & 54 & 3,000 \\
\hline Uganda & & & & & 1,003 & 183 & 820 & 160 & 517 & & 1,950 \\
\hline Original framework & Apr. 97 & Apr. 98 & 202 & & 347 & 73 & 274 & 69 & 160 & 20 & 650 \\
\hline Enhanced framework & Feb. 00 & May 00 & 150 & & 656 & 110 & 546 & 91 & 357 & 37 & 1,300 \\
\hline Zambia & Dec. 00 & Apr. 05 & 150 & & 2,499 & 1,168 & 1,331 & 602 & 493 & 63 & 3,900 \\
\hline \multicolumn{12}{|c|}{ Decision point reached under enhanced framework (8) } \\
\hline Burundi & Aug. 05 & Floating & 150 & & 826 & 124 & 701 & 28 & 425 & 92 & 1,465 \\
\hline Chad & May 01 & Floating & 150 & & 170 & 35 & 134 & 18 & 68 & 30 & 260 \\
\hline Congo, Democratic Republic of & Jul. 03 & Floating & 150 & & 6,311 & 3,837 & 2,474 & 472 & 831 & 80 & 10,389 \\
\hline Congo, Republic of & Mar. 06 & Floating & & 250 & 1,679 & 1,561 & 118 & 8 & 49 & 32 & 2,881 \\
\hline Gambia, The & Dec. 00 & Floating & 150 & & 67 & 17 & 49 & 2 & 22 & 27 & 90 \\
\hline Guinea & Dec. 00 & Floating & 150 & & 545 & 215 & 328 & 31 & 152 & 32 & 800 \\
\hline Guinea-Bissau & Dec. 00 & Floating & 150 & & 416 & 212 & 204 & 12 & 93 & 85 & 790 \\
\hline Haiti & Nov. 06 & Floating & 150 & & 140 & 20 & 120 & 3 & 53 & 15 & 213 \\
\hline \multicolumn{5}{|l|}{ Total assistance provided/committed } & 35,413 & 17,401 & 17,914 & $2,608 \quad 3 /$ & 8,571 & & 62,169 \\
\hline
\end{tabular}

Sources: IMF and World Bank Board decisions, completion point documents, decision point documents, preliminary HIPC documents, and staff calculations.

1/ Assistance levels are at countries' respective decision or completion points, as applicable.

2/ In percent of the net present value of debt at the decision or completion point (as applicable), after the full use of traditional debt-relief mechanisms

3/ Equivalent to SDR 1,728 million at an SDR/US\$ exchange rate of 0.6625, as of March 19, 2007. 


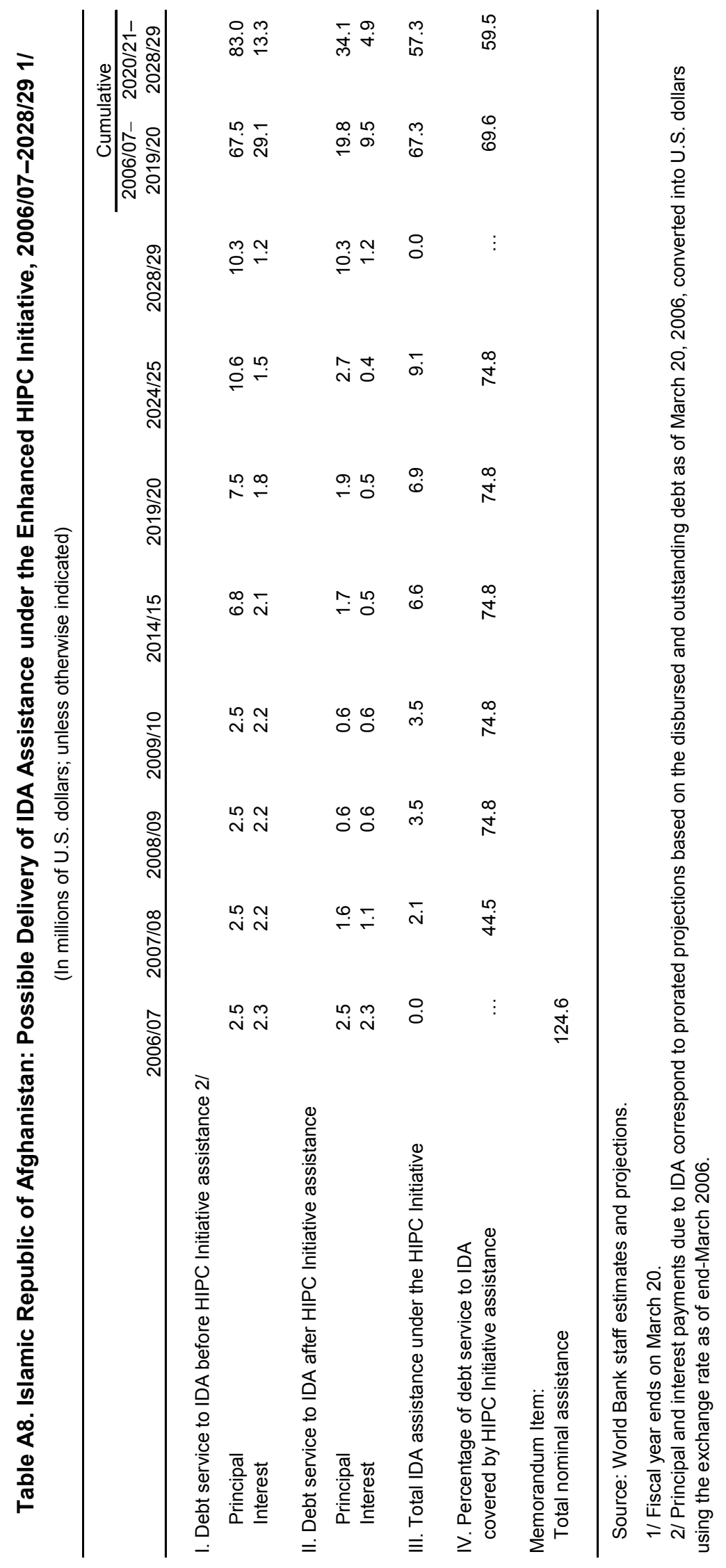




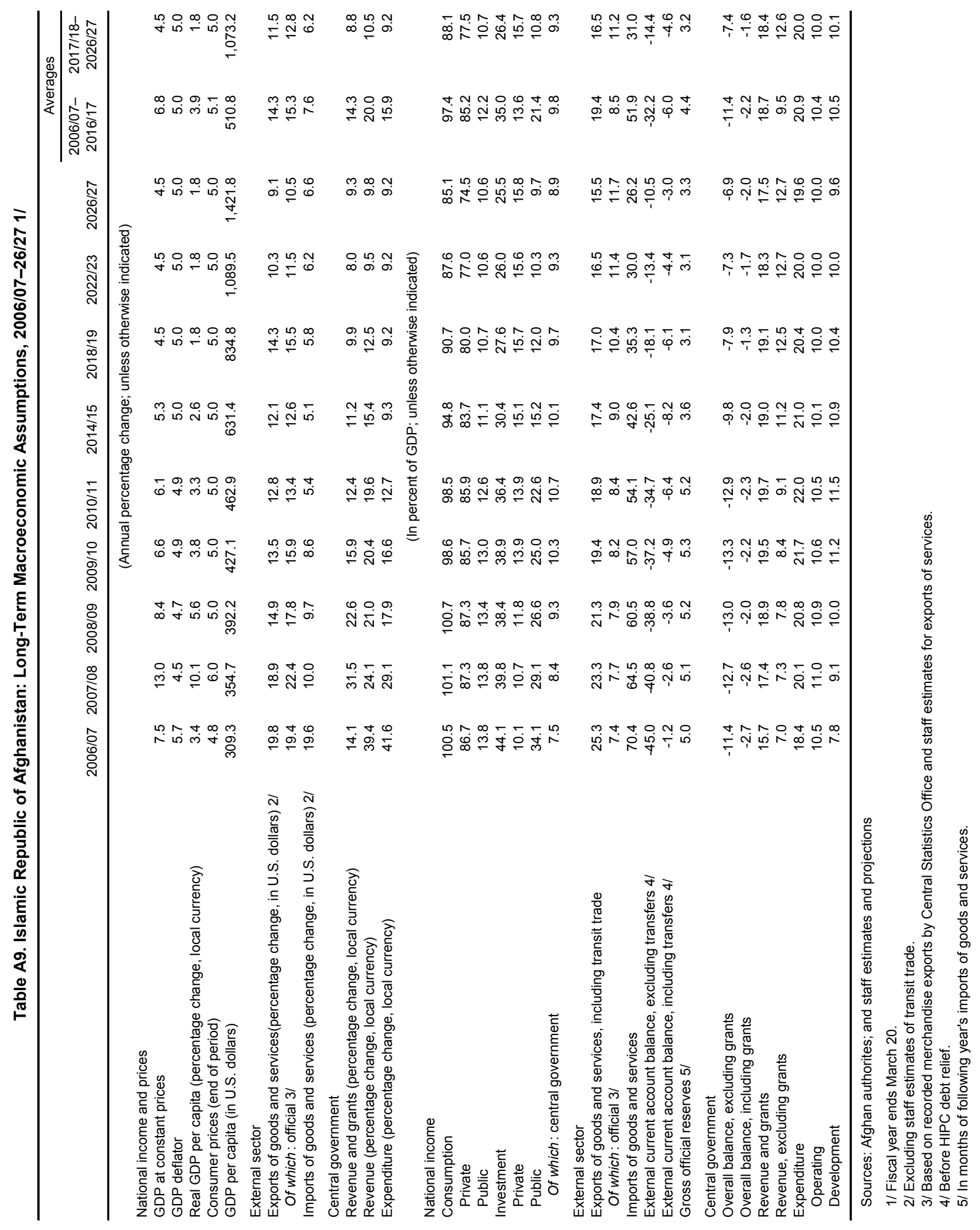




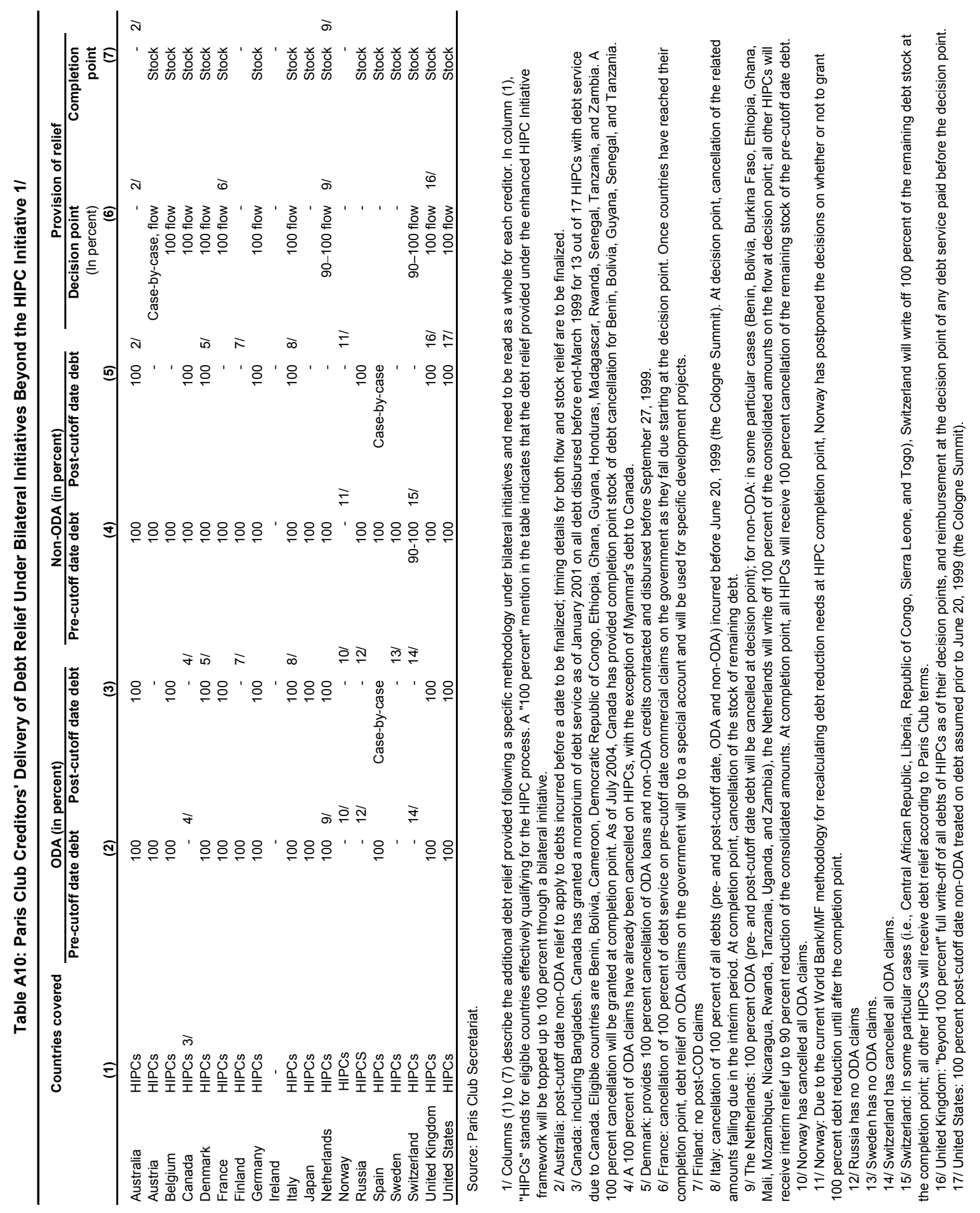


Table A11. Islamic Republic of Afghanistan: Status of Creditor Participation Under the Enhanced HIPC Initiative

\begin{tabular}{|c|c|c|c|c|}
\hline & $\begin{array}{l}\text { Debt Relief in } \\
\text { NPV Terms (in } \\
\text { millions of U.S. } \\
\text { dollars) }\end{array}$ & $\begin{array}{l}\text { Percentage } \\
\text { of Total } \\
\text { Assistance }\end{array}$ & $\begin{array}{l}\text { Satisfactory } \\
\text { Reply to } \\
\text { Participate in } \\
\text { Initiative }\end{array}$ & Modalities to Deliver Debt Relief \\
\hline Total multilateral & 135 & 24 & & \\
\hline World Bank & 75 & 13 & Yes & $\begin{array}{l}\text { Immediately following the approval of the decision point by the } \\
\text { Boards, IDA would begin to provide assistance in the form of } \\
\text { debt-service reduction on debt outstanding and disbursed as of } \\
\text { March 20, } 2006 \text {. }\end{array}$ \\
\hline Asian Development Bank & 59 & 10 & No & $\begin{array}{l}\text { The AsDB is in the process of considering its participation in } \\
\text { HIPC. }\end{array}$ \\
\hline OFID & 1 & 0 & Yes & $\begin{array}{l}\text { OFID has agreed, in principle, to provide HIPC debt relief to } \\
\text { Afghanistan. }\end{array}$ \\
\hline Total bilateral & 436 & 76 & & \\
\hline Paris Club creditors & 420 & 73 & Yes & $\begin{array}{l}\text { Interim assistance is being provided through Cologne flow. Stock } \\
\text { of debt operation under cologne terms ( } 90 \text { percent in NPV } \\
\text { reduction) is expected at completion point. }\end{array}$ \\
\hline Russia & 376 & 66 & Yes & \\
\hline Germany & 7 & 1 & Yes & \\
\hline United States & 37 & 6 & Yes & \\
\hline Non-Paris Club creditors & 17 & 3 & No & $\begin{array}{l}\text { At least Paris Club comparable treatment is expected by other } \\
\text { official bilateral creditors. }\end{array}$ \\
\hline Bulgaria & 8 & 1 & No & \\
\hline Iraq & 2 & 0 & No & \\
\hline Kuwait & 3 & 1 & No & \\
\hline Saudi Arabia & 4 & 1 & No & \\
\hline Croatia & 0 & 0 & No & \\
\hline Total & 571 & 100 & & \\
\hline
\end{tabular}

Sources: Afghan authorities, and staff estimates. 


\section{ApPendiX I-Debt Management CAPACity}

1. The Debt and Asset Management Unit (DAMU) of the Ministry of Finance (MoF) has been responsible for debt management in Afghanistan. ${ }^{1}$ However, the Public Finance and Expenditure Management (PFEM) Law — which provides the legal basis for the DAMU's responsibilities - lacks comprehensiveness and clarity in this regard. The DAMU is working to address significant technical and human resource constraints. Although a U.S. Treasury advisor is providing significant support, the DAMU has an inadequate number of staff with sufficient training to undertake effective debt management.

2. Currently, there is no comprehensive and accurate debt database system. Many old debt records were destroyed during the war, but records of post-2002 multilateral loans are also incomplete. Most debt monitoring is done using ad hoc Excel spreadsheets, and their accuracy is compromised by the lack of a reliable computer network. However, the authorities are exploring options for acquiring a modern debt database and reporting system. Also, the reconciliation processes for the recent Paris Club scheduling agreement and the Enhanced HIPC Initiative have facilitated the authorities' efforts to rebuild their records for all creditors.

3. Under these conditions, the DAMU focuses on providing only essential debt management functions, such as monitoring the external debt stock outstanding, disbursements and debt service paid, and managing debt service payments. Analysis and reporting remain limited, and payments procedures remain weak.

- The DAMU has never undertaken a debt sustainability analysis. Also, coordination between debt management and macroeconomic policy takes place largely through dialogue with the IMF and World Bank. Internal discussions on the budgetary and balance of payments impact of the debt service obligations are typically ad hoc.

- At this time, the DAMU does not prepare or publish a specific report on the authorities' debt strategy. However, consistent with the PFEM Law, the annual budget submission includes information on the existing debt stock, disbursements expected during the coming year, as well as limits on total guarantees and debt.

- Although the DAMU updates its records every payment cycle-for consistency with creditors - it relies heavily on creditor information instead of its own records. Also, procedures for only authorizing debt service payments in local currency create a risk against potential exchange rate movements at the time payments are executed.

4. While the coverage of public and publicly guaranteed external debt is appropriate, continued efforts are needed to build capacity to ensure that the debt is managed in a way

\footnotetext{
${ }^{1}$ Prior to 2003, the central bank, Da Afghanistan Bank, had responsibility for debt management and records.
} 
consistent with long-term debt sustainability. The DAMU should focus on: (i) building and maintaining loan-by-loan data, to rely less on creditors' data; (ii) better tracking disbursements and repayments, and monitoring payments falling due; (iii) training staff; (iv) acquiring a modern debt database and reporting system; (v) building capacity to undertake debt-related macroeconomic, and debt sustainability, analysis. 


\title{
INTERNATIONAL MONETARY FUND AND \\ INTERNATIONAL DEVELOPMENT ASSOCIATION
}

\author{
ISLAMIC REPUBLIC OF AFGHANISTAN
}

\section{Joint World Bank/IMF Debt Sustainability Analysis 2007}

Prepared by the Staffs of the International Monetary Fund and the International Development Association

Approved by Juan Carlos Di Tata and Matthew Fisher (IMF) and Praful Patel and Danny Leipziger (IDA)

June 8, 2007

The external low-income country debt sustainability analysis (LIC DSA) for Afghanistan reveals a high risk of debt distress, ${ }^{1,2}$ emphasizing the need for debt relief under the HIPC Initiative. The public debt LIC DSA suggests that, although Afghanistan's overall public sector debt dynamics remain manageable during the projection period, further fiscal adjustment (or additional grants) will be needed to ensure that domestic debt does not threaten sustainability beyond that horizon.

\section{A. Introduction}

1. The external and public debt sustainability analyses presented in this appendix are based on the common standard LIC DSA framework, ${ }^{3}$ with some modifications to the stress tests to address data limitations in Afghanistan (Box 1). The DSAs present the projected path of Afghanistan's external and public sector debt burden indicators, and draw some conclusions on the forward-looking sustainability of debt. Methodologically, the LIC DSA

\footnotetext{
${ }^{1}$ These DSAs have been produced jointly by Bank and Fund staffs. Afghanistan's fiscal year runs from March 21-March 20.

${ }^{2}$ Afghanistan has not yet been rated under the World Bank's Country Policy and Institutional Assessment (CPIA). However, for the purposes of this analysis, the staff's have conservatively assumed a weak policy rating (and without prejudicing any future CPIA assessment). Accordingly, the corresponding indicative thresholds for the LIC DSA are 30 percent for the NPV of debt-to-GDP ratio, 100 percent for the NPV of debt-to-exports ratio, and 15 percent for the debt service-to-exports ratio. See "Operational Framework for Debt Sustainability Assessments in Low-Income Countries-Further Considerations" (http://www.imf.org/External/np/pp/eng/2005/032805.htm and IDA/R2005-0056, 3/28/05).

${ }^{3}$ See "Debt Sustainability in Low-Income Countries: Proposal for an Operational Framework and Policy Implications" (http://www.imf.org/external/np/pdr/sustain/2004/020304.htm and IDA/SECM2004/0035, 2/3/04) and "Debt Sustainability in Low-Income Countries: Further Considerations on an Operational Framework and Policy Implications" (http://www.imf.org/external/np/pdr/sustain/2004/091004.htm and IDA/SECM2004/0629, 9/10/04).
} 


\section{Box 1. Historical Data Limitations and Use of Comparator Country Data}

Given the absence of data for Afghanistan prior to 2002 and continued data limitations since, the staffs did not judge it appropriate to use Afghanistan's 2-3 year of historical data to conduct the standardized alternative scenarios and stress tests. As an alternative, the analysis uses the historical averages and standard deviations of a group of comparator countries, where appropriate, in both the external and public debt templates.

The group of comparator countries is similar to the one used to impute the value of Afghanistan's exports of services to assess qualification under the HIPC Initiative. ${ }^{1 /}$ In this regard, the ten comparator countries: (i) are PRGF-eligible and meet the World Bank's LIC classification; and (ii) share Afghanistan's key characteristics of being landlocked and either post-conflict or located within the central Asia region. They are: Burundi, Central African Republic, Chad, Ethiopia, Kyrgyz Republic, Mongolia, Niger, Rwanda, Tajikistan, and Uzbekistan.

The data used was estimated based on the most recent 10-year (1997-2006) averages and standard deviations for each country and averaged across the comparator group. In this regard:

- the external debt template uses comparator country data for real GDP growth, the non-interest current account, the US dollar deflator, export value growth and net direct investment. These data are used for the alternative scenario where key variables are at their historical average (Table 2; Scenario A1), as well as the first three bound tests and the combination test (Table 2; Bound Tests B1-B3, B5); and

- $\quad$ the public debt template uses comparator country data on the primary balance and real GDP growth in three alternative scenarios (Table 4; Scenarios A1-A3), and the first three bound tests (Table 4; Bound Tests B1-B3).

Historical Averages \& Standard Deviations, 1997-2006

\begin{tabular}{|c|c|c|c|c|}
\hline & \multicolumn{2}{|c|}{ Comparator Countries } & \multicolumn{2}{|c|}{ Afghanistan } \\
\hline & Average & Std Dev'n & Average & Std Dev'n \\
\hline Real GDP Growth & 4.9 & 4.1 & 11.3 & 4.2 \\
\hline Primary Balance & -1.7 & 3.7 & -0.9 & 4.0 \\
\hline Current Account Balance & -3.4 & 7.1 & 0.3 & 2.6 \\
\hline US\$ deflator (percent change) & 12.7 & 9.7 & 7.5 & 9.8 \\
\hline Value of exports of $\mathrm{G} \& \mathrm{~S}$, percent change & 8.4 & 19.4 & 25.4 & 15.4 \\
\hline
\end{tabular}

The only scenarios/tests not relying on comparator country data are: 30 percent one-time depreciation (external); the lower level of concessionality (external); and the shock to non-debt flows (external). The latter is particularly important given Afghanistan's heavy reliance on official transfers over the projection period (around 40 percent of GDP and 90 percent of official financing). However, as neither Afghanistan's historical data nor comparator country data provide a useful guide for shocks to non-debt flows, the relevant bound tests (Table 2; Bound Tests B4-B5) assume grant financing 25 percent below the baseline projection (or 12 $1 / 2$ percent in the combined test) for 2008/09-2009/10.

1/ See Box 2 of "Islamic Republic of Afghanistan: Enhanced Heavily Indebted Poor Countries InitiativeDecision Point Document" (refer to www.imf.org). 
differs from the HIPC DSA in that forward-looking debt ratios, based on single year denominators, are assessed against policy-dependent indicative thresholds. In contrast, under a HIPC DSA, debt ratios are derived on the basis of three-year backward-looking averages and assessed against uniform thresholds across countries. ${ }^{4}$

\section{B. Baseline Scenario}

2. The baseline scenario relies on the same long-run macroeconomic framework as that underlying the HIPC debt relief analysis ${ }^{5}$ and is consistent with the program projections under the PRGF arrangement. Average annual real GDP growth is projected to moderate over the projection period, from 6.8 percent in 2006/07-2016/17 to 4.5 percent in 20017/18-2026/27. This pattern reflects the projected decrease in the investment-to-GDP ratio from short- to medium-term exceptional levels above 40 percent, to a still high yet markedly lower long-term level (around 25 percent). The latter is necessary to sustain an acceptable pace of growth in per capita consumption. Continued donor support for reconstruction and public investment is likely to be the main driving factor during the earlier years. The contribution of donor-led investment is expected to decline over the medium term with private investment gaining in prominence and eventually playing the lead role. After temporarily reaching 6.0 percent in 2007/08, inflation is projected to ease to 5 percent during the remainder of the projection period.

3. Continued macroeconomic stability is predicated on a sustained fiscal discipline, with the government's overall deficit (including grants) not exceeding $2 \frac{1}{2}$ percent of GDP over the projection period. Underlying this, revenues are assumed to increase gradually from 7 percent of GDP in 2006/07 to 12.7 percent of GDP in 2026/27, while expenditures are expected to peak at just over 22 percent of GDP in 2010/11 and stabilize below 20 percent of GDP by $2026 / 27$.

\section{The external position is expected to remain manageable with continued donor} support over the medium term. Over the longer term, the current account deficit (excluding grants) is projected to improve gradually from over 45 percent of GDP in 2006/07 to around 10 percent in 2026/27. External grants are expected to remain the predominant form of financing, ${ }^{6}$ but decreasing as a percentage of GDP from just under 44 percent in 2006/07 to around 7.5 percent in 2026/27. As official transfers taper off as a percent of GDP, the current account deficit (including grants) could widen over the medium term reflecting still significant development-related imports and the projected pick-up in private investment

\footnotetext{
${ }^{4}$ In addition, the results of the LIC DSA differ from the HIPC DSA (main text) because of two other methodological differences related to the definition of: (i) discount rates; and (ii) exchange rates.

${ }^{5}$ See Box 3 of "Islamic Republic of Afghanistan: Enhanced Heavily Indebted Poor Countries InitiativeDecision Point Document" (refer to www.imf.org).

${ }^{6}$ Official borrowing is assumed to continue on strictly concessional terms.
} 
(expected to be mainly financed by foreign direct investment). After averaging around 6.0 percent of GDP in 2006/07-2016/17, the external current account deficit (including grants) is anticipated to narrow to 4.6 per year in 20017/18-2026/27 (and reach 3 percent of GDP toward the end of the projection period). Income growth and improved financial intermediation are expected to stimulate private sector savings and result in a narrowing of the private sector savings-investment deficit in the long term.

5. The baseline scenario assumes full delivery of traditional debt relief. Consistent with the baseline scenario presented for the second review under the PRGF-supported program, a financing gap is expected to be met through interim HIPC assistance as proposed for the decision point. At this stage, the baseline does not reflect the conditional delivery of HIPC assistance at the completion point; however, this is presented in an alternative scenario. ${ }^{7}$

\section{Debt Sustainability Analyses}

\section{External Debt Sustainability}

6. The baseline scenario, which assumes full delivery of traditional debt relief and a financing gap to be met through HIPC interim assistance, indicates that Afghanistan has a high risk of debt distress (Table 1). Although the NPV of external debt-to-GDP ratio remains well below the threshold (30 percent), the NPV of external debt-to-exports ratio remains persistently above the 100 percent threshold, reflecting Afghanistan's very narrow export base. Also, the relatively comfortable debt service ratios (to export and revenue) are attributable to the very high degree of concessionality on the outstanding stock of debt from multilaterals (mainly on IDA or IDA-like terms).

7. The alternative scenarios and stress tests indicate that the evolution of Afghanistan's external debt position is subject to considerable vulnerabilities (Table 2, Figure 1). In particular, most debt indicators deteriorate significantly under the bound tests (temporary shocks) and in the face of a permanent (unfavorable) shock to the terms of new borrowing. In sharp contrast, the debt ratios improve under the historical scenario-main variables at historical average (using comparator countries) over the projection period. However, given the lack of historical data and the reliance on comparator country averages, these results should be treated cautiously. Other analyses are likely to provide more pertinent guidance in assessing Afghanistan's debt vulnerabilities.

8. Both the scenario with less favorable terms on new borrowing and the temporary shock to non-debt creating flows underscore the vulnerabilities posed by Afghanistan's heavy reliance on official transfers and highly concessional borrowing. A deterioration in borrowing terms by 200 basis points would delay Afghanistan's NPV of

\footnotetext{
${ }^{7}$ See "Staff Guidance Note on the Application of the Joint Bank-Fund Debt Sustainability Framework for Low-Income Countries" (refer to www.imf.org and IDA/SECM2007/0226, 03/05/2007).
} 
external debt-to-exports ratio falling below the threshold from 2015/16 (baseline) to 2019/20. The impact of 25 percent less official transfers over 2008/09-2009/10 would be far more dramatic, with the NPV of external debt-to-exports ratio rising to 268 percent in $2009 / 10$ and then not falling below the threshold until 2021/22.

9. The bound tests also demonstrate that an improvement in Afghanistan's external debt indicators depends heavily on an expansion of the very narrow export base and limited export capacity. If export growth during 2008/09 and 2009/10 were to fall to a level one standard deviation below the historical average, the NPV of external debt-to-exports would spike to 278 percent in 2009/10 and would not fall below the threshold until 2023/24. Under the combination stress test, reflecting both lower transfers and lower export growth, even the ratio of debt service-to-exports (14 percent) would approach the threshold (15 percent) in 2015/16.

10. Financial assistance under the HIPC and Multilateral Debt Relief Initiatives (MDRI) improve significantly Afghanistan's debt situation. Assuming the full delivery of HIPC and MDRI assistance, all three debt-burden indicators (NPV of debt-to-GDP ratio, NPV of debt-to-exports ratio, and debt service-to-exports ratio) would be significantly below the indicative thresholds.

\section{Public Sector Debt Sustainability}

11. Under the baseline scenario, Afghanistan's public debt (including domestic debt) is expected to decline steadily as a percent of GDP until 2020/21, before increasing again (Table 3 ). In the short term, the government is also running down its significant deposits at Da Afghanistan Bank (the central bank), which together with generous grant financing, explains the initial decline in the public debt ratios. However, the availability of external grants is expected to decline as a share of GDP over the projection period, from a high of just over 11 percent of GDP in 2009/10 to just under 5 percent of GDP in 2027/28. Notwithstanding the assumed steady growth of domestic revenue (excluding grants), the expected decline in grants will contribute to a pick up in the public debt ratios in the second half of the projection period.

12. The medium- to longer-term decline in external grant financing is expected to be offset by a combination of increased revenue and domestic borrowing. By 2027/28 domestic debt is projected to reach 11.4 percent of GDP from a zero base in 2007/08, under the expectation of gradual development in the domestic debt market. While the level of public debt over the projection period will not endanger fiscal sustainability, the average long run primary deficit, at 1.3 percent of GDP, is above the level that stabilizes the debt to GDP ratio.

13. Debt dynamics remain manageable under the various stress tests (Table 4).

Although the one standard deviation shock to GDP doubles the NPV of debt-to-GDP ratio to 25 percent, relative to the baseline, this remains below the relevant country specific debt 
burden thresholds for countries rated as weak performers against the World Bank's CPIA. Baseline projections for the evolution of debt ratios are not seen to be overly optimistic as they do not differ significantly from historical trends. ${ }^{8}$

\section{Debt Distress Classification and Conclusion}

\section{Afghanistan's risk of debt distress is high.}

- The baseline path of NPV of external debt-to-exports remains above the LIC DSA threshold (100 percent) until 2015/16. The sensitivity analysis indicates that Afghanistan's external debt sustainability is heavily dependant on the continued availability of mainly official grant financing, supplemented by highly concessional loans.

- The emerging role of domestic debt financing over the longer term does not pose an immediate risk to the debt outlook, but it does underscore the need for cautious approach to fiscal policy as the government builds the domestic revenue base and given uncertainties about the pace of donor expenditures being brought on budget. While the level of public debt remains manageable over the projection period, the government will need additional grant financing and/or fiscal consolidation to contain the debt dynamics beyond that horizon.

\footnotetext{
${ }^{8}$ Care should be taken when making this comparison on account of the methodology used to overcome the lack of historical data in Afghanistan.
} 


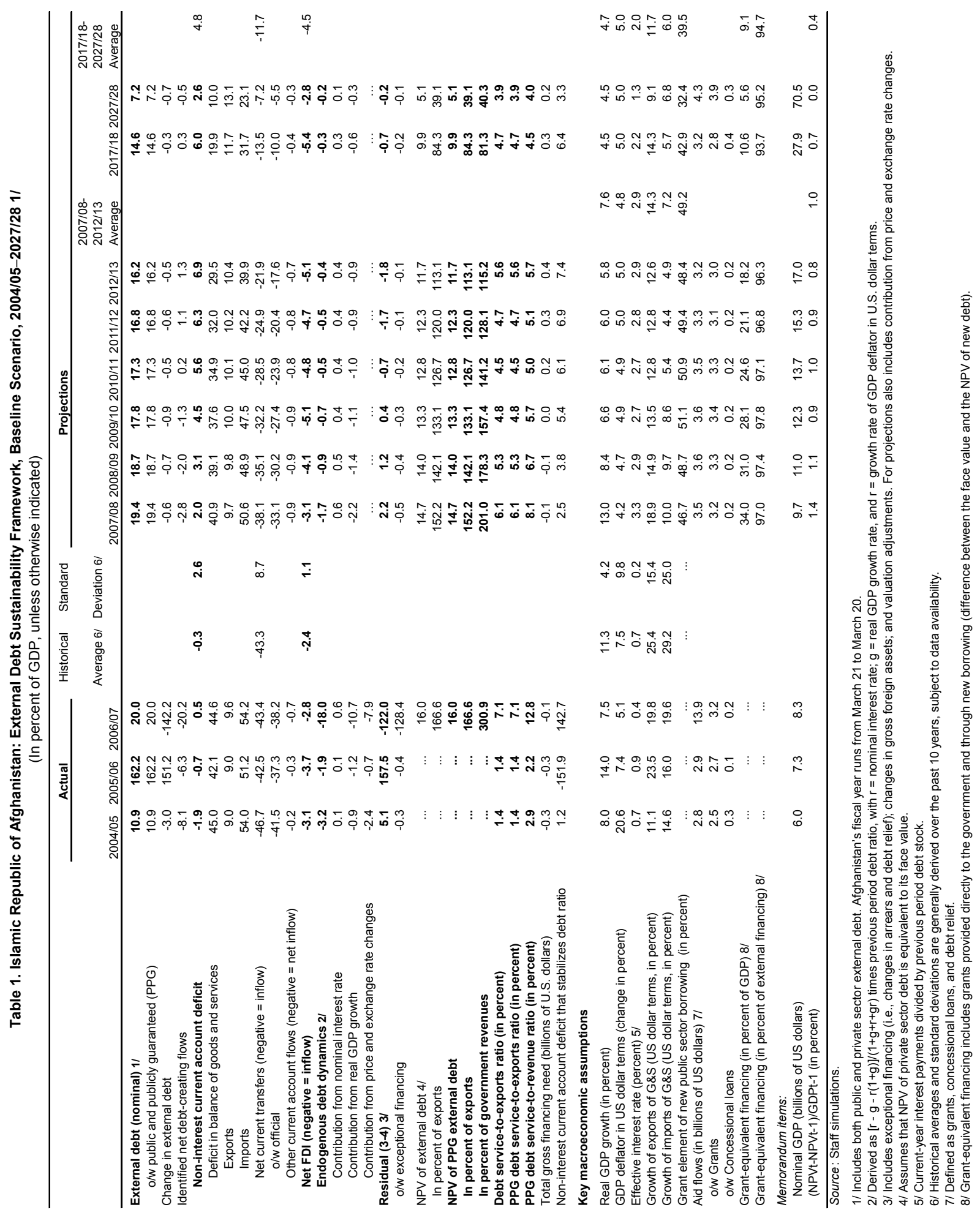


Table 2. Islamic Republic of Afghanistan: Sensitivity Analyses for Key Indicators of Public and Publicly Guaranteed External Debt, 2007/08-27/28 (In percent)

\begin{tabular}{|c|c|c|c|c|c|c|c|c|c|}
\hline & & & & Project & tions $1 /$ & & & & \\
\hline & $2007 / 08$ & $2008 / 09$ & $2009 / 10$ & $2010 / 11$ & $2011 / 12$ & $2012 / 13$ & $2017 / 18$ & $2027 / 28$ & \\
\hline NPV of debt-to-G & ratio & & & & & & & & \\
\hline Baseline & 15 & 14 & 13 & 13 & 12 & 12 & 10 & & 5 \\
\hline A. Alternative Scenarios & & & & & & & & & \\
\hline A1. Key variables at their historical averages in 2008/09-27/28 2/ & 15 & 15 & 14 & 13 & 11 & 10 & 6 & 6 & 6 \\
\hline A2. New public sector loans on less favorable terms in $2008 / 09-27 / 283 /$ & 15 & 14 & 14 & 14 & 14 & 13 & 13 & & 8 \\
\hline A3. Full delivery of HIPC assistance \& MDRI & 7 & 7 & 8 & 8 & 8 & 7 & 8 & 5 & 5 \\
\hline B. Bound Tests & & & & & & & & & \\
\hline B1. Real GDP growth at historical average minus one standard deviation in 2008/09-09/10 & 15 & 15 & 15 & 15 & 14 & 13 & 11 & & 6 \\
\hline B2. Export value growth at historical average minus one standard deviation in 2008/09-09/10 4/ & 15 & 15 & 17 & 16 & 15 & 15 & 12 & & 6 \\
\hline B3. US dollar GDP deflator at historical average minus one standard deviation in $2008-09$ & 15 & 14 & 14 & 13 & 13 & 12 & 10 & & 5 \\
\hline B4. Net non-debt creating flows 25 percent below the baseline in 2008/09-09/10 5/ & 15 & 21 & 27 & 25 & 24 & 23 & 17 & & 7 \\
\hline B5. Combination of B1-B4 using one-half standard deviation shocks & 15 & 20 & 27 & 25 & 24 & 23 & 17 & & 8 \\
\hline B6. One-time 30 percent nominal depreciation relative to the baseline in $2008 / 096 /$ & 15 & 20 & 19 & 18 & 17 & 16 & 14 & & 7 \\
\hline NPV of debt-to-exp & s ratio & & & & & & & & \\
\hline Baseline & 152 & 142 & 133 & 127 & 120 & 113 & 84 & 39 & 39 \\
\hline A. Alternative Scenarios & & & & & & & & & \\
\hline A1. Key variables at their historical averages in $2008 / 09-27 / 28$ 2/ & 152 & 149 & 142 & 129 & 112 & 95 & 51 & 44 & 44 \\
\hline A2. New public sector loans on less favorable terms in 2008/09-27/28 3/ & 152 & 146 & 140 & 136 & 132 & 128 & 107 & 60 & 60 \\
\hline A3. Full delivery of HIPC assistance \& MDRI & 74 & 76 & 75 & 75 & 74 & 72 & 64 & 38 & 38 \\
\hline B. Bound Tests & & & & & & & & & \\
\hline B1. Real GDP growth at historical average minus one standard deviation in 2008/09-09/10 & 152 & 142 & 133 & 127 & 120 & 113 & 84 & 39 & 39 \\
\hline B2. Export value growth at historical average minus one standard deviation in 2008/09-09/10 4 / & 152 & 201 & 278 & 263 & 248 & 233 & 164 & 71 & 71 \\
\hline B3. US dollar GDP deflator at historical average minus one standard deviation in 2008-09 & 152 & 142 & 133 & 127 & 120 & 113 & 84 & 39 & 39 \\
\hline B4. Net non-debt creating flows 25 percent below the baseline in 2008/09-09/10 5/ & 152 & 212 & 268 & 251 & 235 & 219 & 142 & 54 & 54 \\
\hline B5. Combination of B1-B4 using one-half standard deviation shocks & 152 & 221 & 316 & 297 & 278 & 260 & 172 & 68 & 68 \\
\hline B6. One-time 30 percent nominal depreciation relative to the baseline in $2008 / 096 /$ & 152 & 142 & 133 & 127 & 120 & 113 & 84 & 39 & 39 \\
\hline
\end{tabular}

Debt service-to-exports ratio

\section{Baseline}

\section{A. Alternative Scenarios}

A1. Key variables at their historical averages in 2008/09-27/28 2/

A2. New public sector loans on less favorable terms in 2008/09-27/28 3/

A3. Full delivery of HIPC assistance \& MDRI

\section{B. Bound Tests}

B1. Real GDP growth at historical average minus one standard deviation in 2008/09-09/10

B2. Export value growth at historical average minus one standard deviation in 2008/09-09/10 4/

B3. US dollar GDP deflator at historical average minus one standard deviation in 2008-09

B4. Net non-debt creating flows 25 percent below the baseline in 2008/09-09/10 5/

B5. Combination of B1-B4 using one-half standard deviation shocks

B6. One-time 30 percent nominal depreciation relative to the baseline in 2008/09 6/

Memorandum item

Grant element assumed on residual financing (i.e., financing required above baseline) 71

Source: Staff projections and simulations.

1/ Afghanistan's fiscal year runs from March 21 to March 20

2/ Variables include real GDP growth, growth of GDP deflator (in U.S. dollar terms), non-interest current account in percent of GDP, and non-debt creating flows. Given that Afghanistan has only limited historical data, the historical average scenario was based on 10-year averages of comparator countries (see Box B1).

$3 /$ Assumes that the interest rate on new borrowing is by 2 percentage points higher than in the baseline, while grace and maturity periods are the same as in the baseline.

4/ Exports values are assumed to remain permanently at the lower level, but the current account as a share of GDP is assumed to return to its baseline level after the shock (implicitly assuming an offsetting adjustment in import levels).

$5 /$ Includes official and private transfers and FDI.

6/ Depreciation is defined as percentage decline in dollar/local currency rate, such that it never exceeds 100 percent.

7/ Applies to all stress scenarios except for A2 (less favorable financing) in which the terms on all new financing are as specified in footnote 2 . 


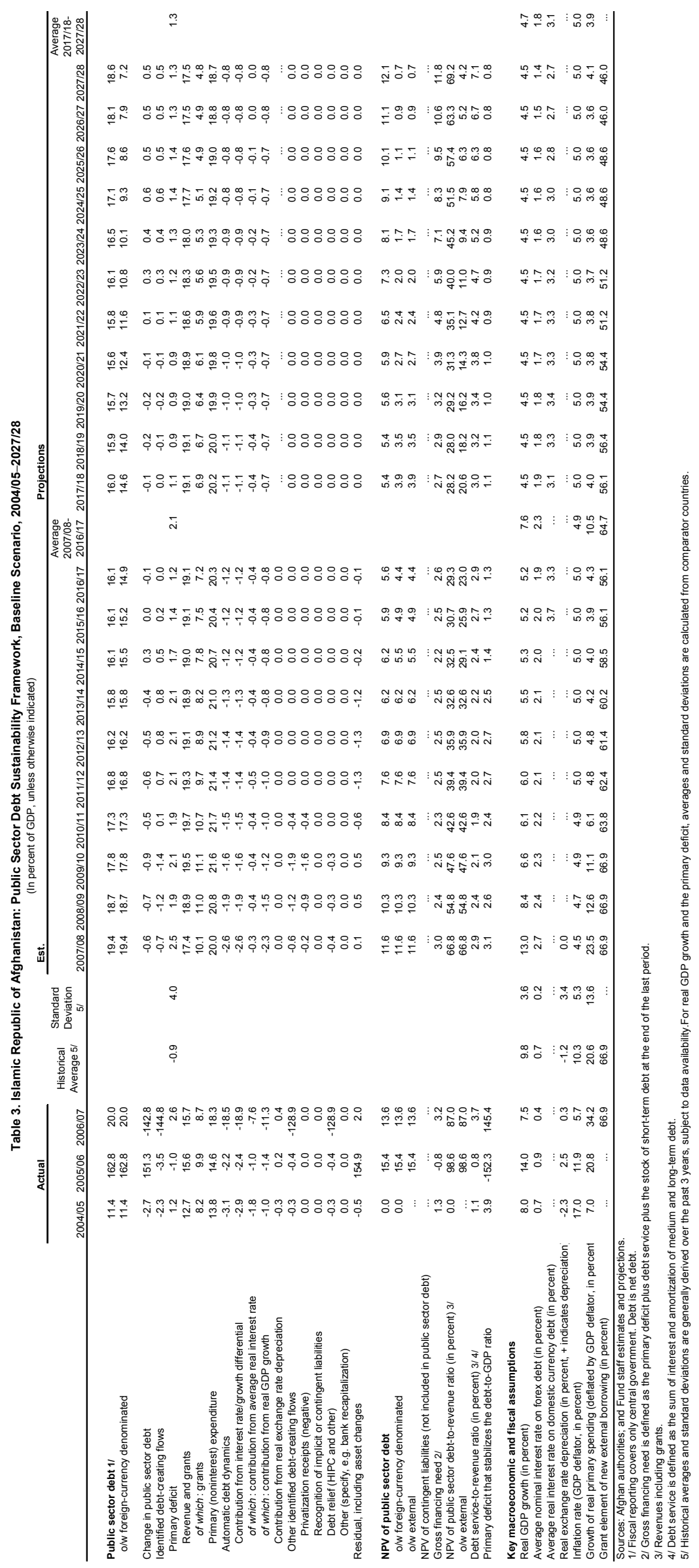


Table 4. Islamic Republic of Afghanistan: Sensitivity Analysis for Key Indicators of Public Debt 2007/08-2027/28

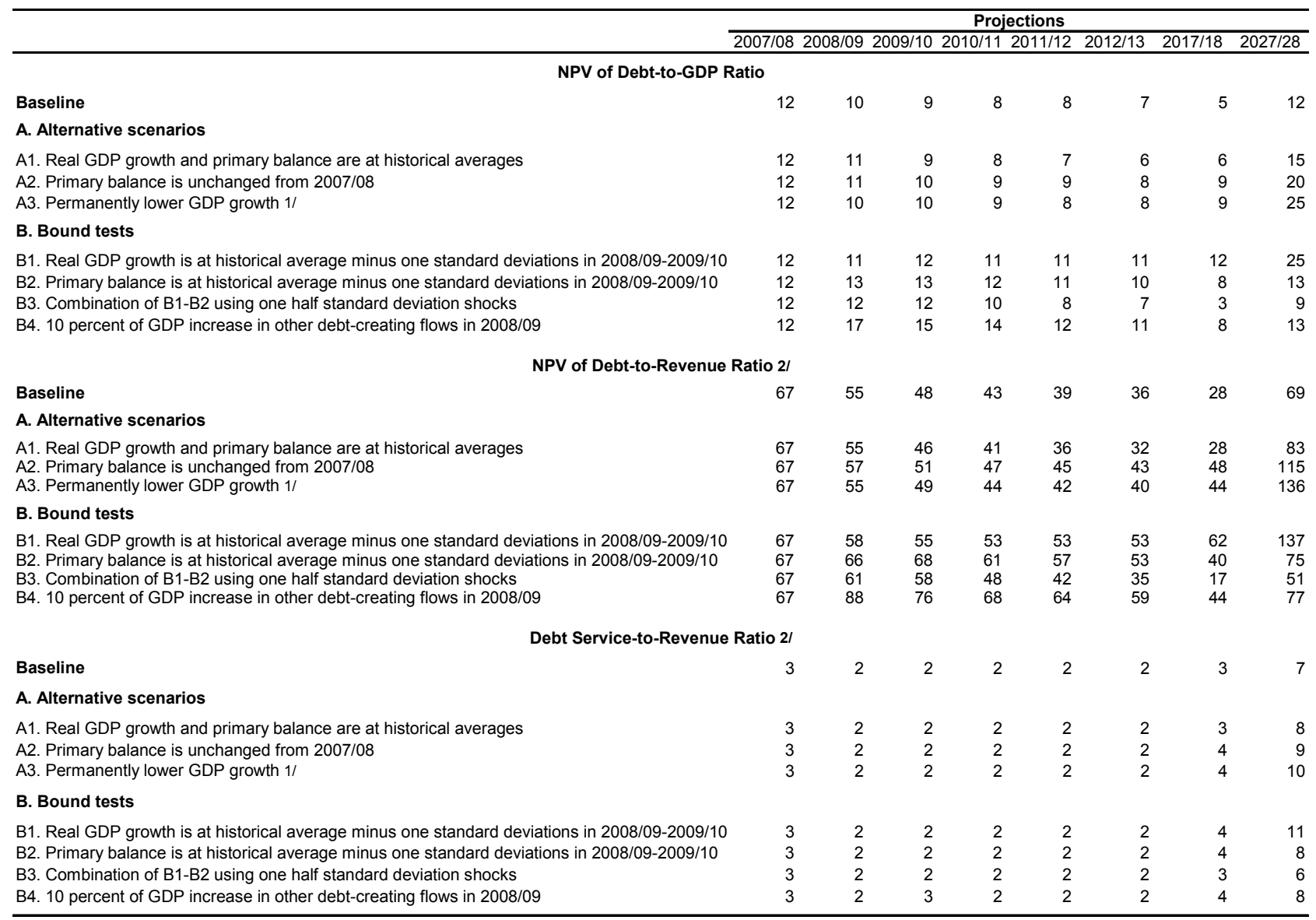

Sources: Afghan authorities; and Fund staff estimates and projections.

$1 /$ Real GDP growth is assumed to be the average of the comparator group minus one standard deviation divided by the square root of 20 (i.e., the length of the projection period).

2/ Revenues are defined inclusive of grants. 
Figure 1. Islamic Republic of Afghanistan: Indicators of Public and Publicly Guaranteed External Debt Under Alternative Scenarios, 2007/08-2027/28 $1 /$
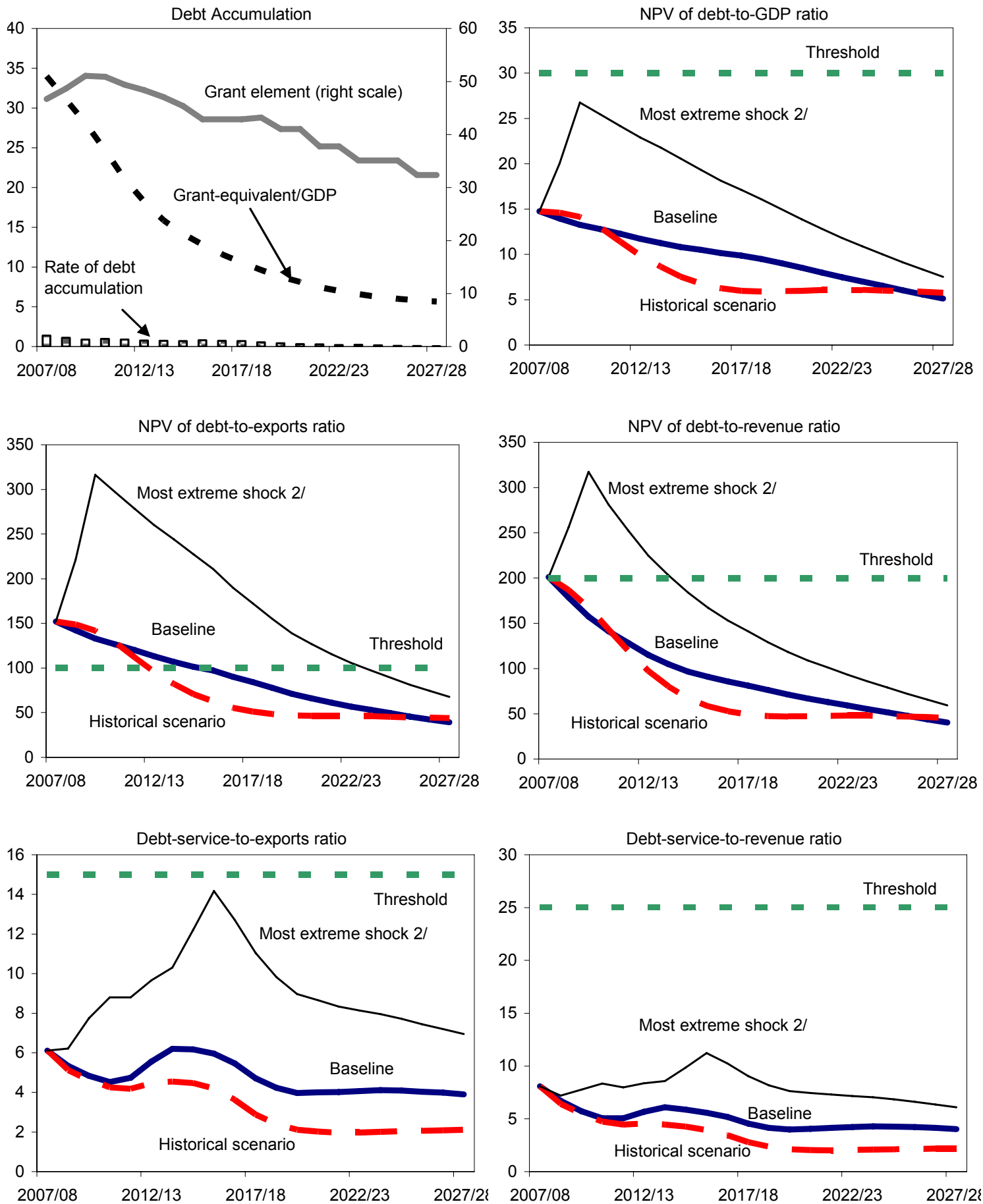

Sources: Staff projections and simulations.

1/ Afghanistan's fiscal year runs from March 21 to March 20.

2/ Combination shock B5 (see Table 2), using one-half standard deviation shocks. 
Figure 2. Islamic Republic of Afghanistan: Indicators of Public Debt Under Alternative Scenarios, 2007/08-2027/28
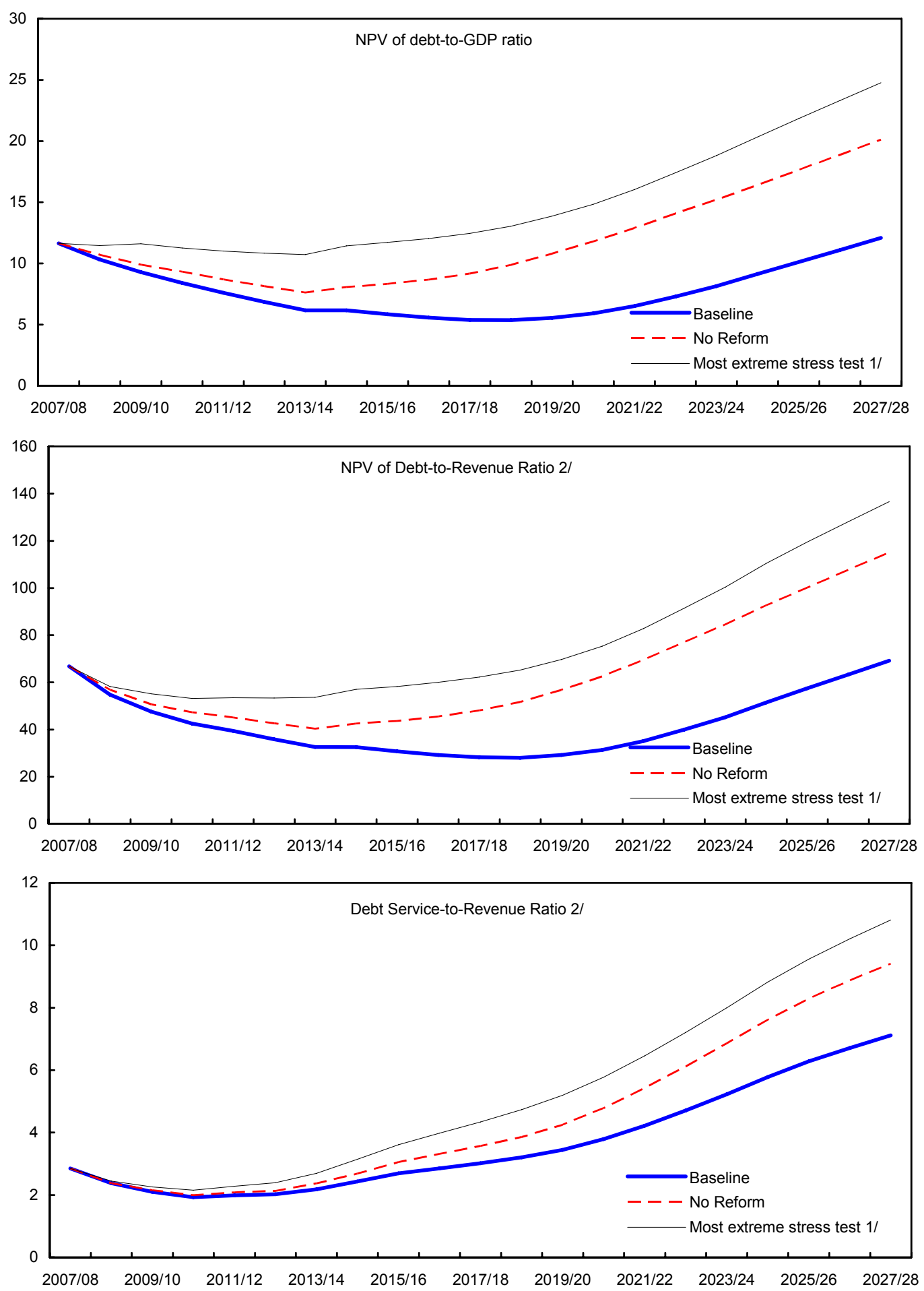

Source: Staff projections and simulations.

$1 /$ Most extreme stress test is that which yields highest ratio in 2017/18. This resulted from the stress test under which real GDP growth in 2008/09 and 2009/10 was at historical average minus one standard deviation (based on comparator country data). 2/ Revenue including grants. 